STATE OF ALASKA

Kelth H. Miller - Governor

DEPARTMENT OF NATURAL RESOURCES

Thomas E. Kelly - Commisstonex

DIVISION OF MINES AND GEOLOGY

James A. Wiliiams - Director

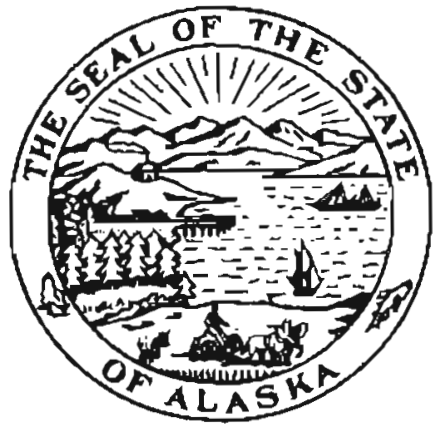

GEOLOGICAL REPORT NO. 41

An Experlment in Geobotanical prospecting for Urantum, Bokan Mountain Area, Southeastern Alaska

By

Gilbert R. Eakins

College, Alaska

August 1970 
AgSTRACT , . . . . . . . . . . . . . . . . . . . . . . . . . . . . . 1

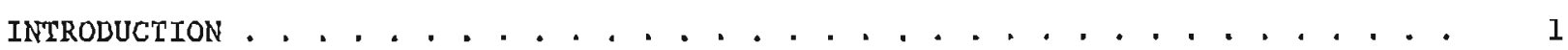

Objectives . . . . . . . . . . . . . . . . . . . . . . . . . . . . . . . 1

Location and Access. . . . . . . . . . . . . . . . . . . . . . . . 2

Climate and Vegetation . . . . . . . . . . . . . . . . . . . . 2

Previous Work. . . . . . . . . . . . . . . . . . . . . . . . . 5

ACKNOWLEDGEMENTS . . . . , . . . . . . . . . . . . . . . . . . . . . . . . 8

GENERAL GEOLOGIC SETTING . . . . . . . . . . . . . . . . . . . . . . . . . . 8

MINING OF NONRADIOACTIVE MATERIALS . . . . . . . . . . . . . . . . . . . . 9

GEOLOGY OF THE BOKAN MOUNTAIN URANIUM-THORIUM AREA . . . . . . . . . . . . . . . 9

Bedrock. . . . . . . . . . . . . . . . . . . . . . . . . . . . . . 9

Urantum-'Thorium Deposits . . . . . . . . . . . . . . . . . . . . 10

Ross-Adams Mine. . . . . . . . . . . . . . . . . . . . . . . . . ., 11

Mineralogy . . . . . . . . . . . . . . . . . . . . . . 11

ore Genesis. . . . . . . . . . . . . . . . . . . . . . . . 15

Other Claims and Prospects . . . . . . . . . . . . . . . . . 15

BIOGEOCHEMICAL PROSPECTING METHODS . . . . . . . . . . . . . . . . . . . . 17

SAMPLING PROCEDURE . . . . . . . . . . . . . . . . . . . . . . . . . . 18

ANALYTICAL METHODS . . . . . . . . . . . . . . . . . . . . . . . . . . 21

SAMPLING RESULTS . . . . . . . . . . . . . . . . . . . . . . . . . . 22

CONCLUSIONS . . . . . . . . . . . . . . . . . . . . . . . . . . . . . 24

REFERENCES . . . . . . . . . . . . . . . . . . . . . . . . . . 51

I L L U S T R A T I O N S

Figure 1 Location map - Bokan Mountain area, Alaska.............. . 3

2 Bokan Mountain urantum-thoriun area . . . . . . . . . . . . . . . . 4

3 Location of the Ross-Adams mine . . . . . . . . . . . . . . . . 5

4 Typical vegetation of the Ross-Adams mine . . . . . . . . . . . . . 6

5 Ross-Adams mine open plt . . . . . . . . . . . . . . . . . . . 6

6 Core drilling at the Ross-Adams mine . . . . . . . . . . . . . . . . 7

7 Part of the Bokan Mountaln area showlag fracture pattern... . . . 12

8 Sketch map Ross-Adams mine. . . . . . . . . . . . . . . . . . . . 13 
Figure 9 Ross-Adams mine radiometric survey of maln opencut and upper adit. .4

10 Sketch map of mire area showing sample locations. . . . . . . . . . 16

11 Ross-Adams mine ared soil thickness and surface-slope . . . . . . I9

12 Index map showing al1 sample jocations and numbers... . . . . . . 20

13 Sample locations living lodgepole plne . . . . . . . . . . . . . . . 25

14 Sanple locations dead lodgepole pine and burls . . . . . . . . . . . 26

15 Sauple localions spruce . . . . . . . . . . . . . . . . . . . . . . 27

16 Sample locations western cedar . . . . . . . . . . . . . . . . . . . 28

17 Sample localions western liemlock. . . . . . . . . . . . . . . . 24

18 Sanple locations junfper . . . . . . . . . . . . . . . . . . . . . . 30

19 Sample locations blueberry . . . . . . . . . . . . . . . . . . . 31

20 Sample locations algre . . . . . . . . . . . . . . . . . . . . . . 32

21 Sample location's miscellaneous plants . . . . . . . . . . . . . . . . . 3.3

22 Sample locations mulch and soil . . . . . . . . . . . . . . . . 34

23 Sample locations strean sediment. . . . . . . . . . . . . . . . . . 35

Table 1 living lodgepoje plne ash analyses . . . . . . . . . . . . . . . . . . . . . . 36

2 Dead lodgepole pline and burls ash analyses... . . . . . . . . . 39

3 Spruce ash analyses... . . . . . . . . . . . . . . 40

4 Western cedar ash analyses. . . . . . . . . . . . . . . . . . 1,

5 Western hemlock ash analyses. . . . . . . . . . . . . . . . . . . . 44

6 Juniper ash analyses... . . . . . . . . . . . . . . . . . . 4 45

7 Blueberry ash analyses. . . . . . . . . . . . . . . . . . 46

8 Algae ash analyses . . . . . . . . . . . . . . . . . . . . . 46

9 Miscellaneous plants ash analyses . . . . . . . . . . . . . . 47

10 Mulch and soil analyses . . . . . . . . . . . . . . . . . . . . . 48

11 Scream sediment analyses. . . . . . . . . . . . . . . . . . . . . . 49

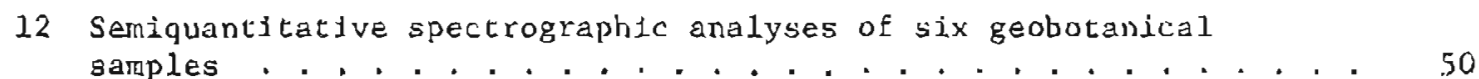


AN EXPERIMENT IN GEOBOTANICAL PROSPECTING FOR URANIUN,

BOKAN MOUNTAIN AREA, SOUTHEASTERN ALASKA

By

Gilbert R. Eakins

A. B S S T R R A C

A project was conducted at the koss-Adams uranfum mine to determine the uselulness of various sample types in uranium exploration in Alaska, where conditions present unusual difficulties. A total of 421 samples were collected, including several varteties of plants, mulch, algae, and stream sediments. The Ross-Adams ore deposit ts a uraniumthorium concentration in a small stock of peralkaline granite. The area was selected for testing various types of sampling because the mine has produced high-grade ore and the geology is known.

Highly anomalous uranium values were obtalned from the ashed plants and other materials. The highest value of 2396 parts per million uranium was obtained from lodgepole plne. Lleven assay maps illustrate the results of sampling different plancs, mulch, and stream sedinents. Other maps show a fracture pactern, mine workings, and radiometric surveys. The analyses indicate that the lodgepole pine is the most suitable plant for geobotanical prospecting in the area, Some evidence suggest that mulch and stream sed1ments nay be useful for uranium prospecting.

I N

OBJECTIVES

This report is the second by the Division of Mines and Geology directed toward assisting those prospecting Eor urantum in Alaska (Eakins, 1969). Difficulties 1n radiometric prospecting for uranium over large parts of Alaska, besides the usual ones of remoteness and rugged terrain, are: the presence of cundra cover, dense vegetation, humid climatic conditions, permafrost, complex geologic structure, and widespread metamorphism of both igneous and sedimentary rocks. These conditions prompted the writer to undertake a biogeochemical prospecting project in an efforc to learn if the method would be useful within this otate. 
The area selected For sampling was the Bokan Mountaln uranium-thorlum district near the southern end of Prince of Wales Island. High-grade uranium ore has been produced from an alkali granite stock at the Ross-Adams mine, and radioactivicy has been found at numerous sites within the surrounding area. The wricer spent the nonth of August, 1969, collecting samples and examining the geology of the mine and nearby prospects.

Evaluation of the properties and general exploration programs by private companies are currently in progress. Competition is very keen, and therefore it would not be appropriate for the writer to attempt a discussion of ore reserves or the economic possibilities of mining properties at this time.

LOCATION AND ACCESS

The Bokan Mountain urantum-thortum area, as defined by Mackevett (1963), 1ncludes a norchwest trending tract of roughly 70 square miles located on the east side of the southern part of Prince of Wales Island ( $\hat{f} \dot{g}$ 1), Except for a small strip along the eastern shoreline of the Island which falls in the Prince Rupert D-6 quadrangle, the area is in the Dixon Entrance D-l quadrangle. The most Important deposit of uranium found so far is at the Ross-Adams mine on the southeast side of Bokan Mountain at an elevation of 950 feet ( $\mathrm{fig} 2 \& 3$ ). It is about one and three-fourths miles by road Erom the head of the West Arm of Kendrlck Bay, where Newmont Exploration Limited has a camp and dock. The camp is approximately 40 miles southwest of Ketchikan. It is served by chartered boats and float planes, both of which are avaflable in Kerchikan,

Except Eor the short road between the bay and the Ross-Adams mine, land travel 1s by Foot and generally very difficult. A few trails leading to some claims are not maintained and not easily followed. Hellcupters belng used by exploration groups can be landed at rather widely-spaced clearings at the higher elevations.

\section{CLIMATL AND VEGLTATION}

The climate of southern Prince of Wales Island is not severe, but prectpitation is heavy, espectally during the spring and sumer. Strong wind storms are always a possibility. The U. S. Jepartment of Cominerce (1968, p 10) recorded an average annual precipitation of 18 inches during the last 10 years at the Annette Island airport, twenty miles northeast of Kendrick Bay. Temperature extremes at the same location were a low of $l^{\circ} \mathrm{F}$ and a high of $90^{\circ} \mathrm{F}$.

Vegetation varles from very dense in rain forests at the lower elevations to nearly absent along rocky slopes, which range up to 2500 feet at Bokan Mountain. Many of the middle and higher areas where soil is thin support only stunted trees and scrub brush. Swanips and muskeg exist where drainage is poor. Forests contain large spruce, cedar, and hemlock, which often have trunks up to four or five feet in diameter. Fallen trees and dense brush consisting of berry bushes, devils club, and other low-growing varietles make some places nearly impenetrable. Thick mosses cover everything in the well-shaded forests ( $f i g$ ). 


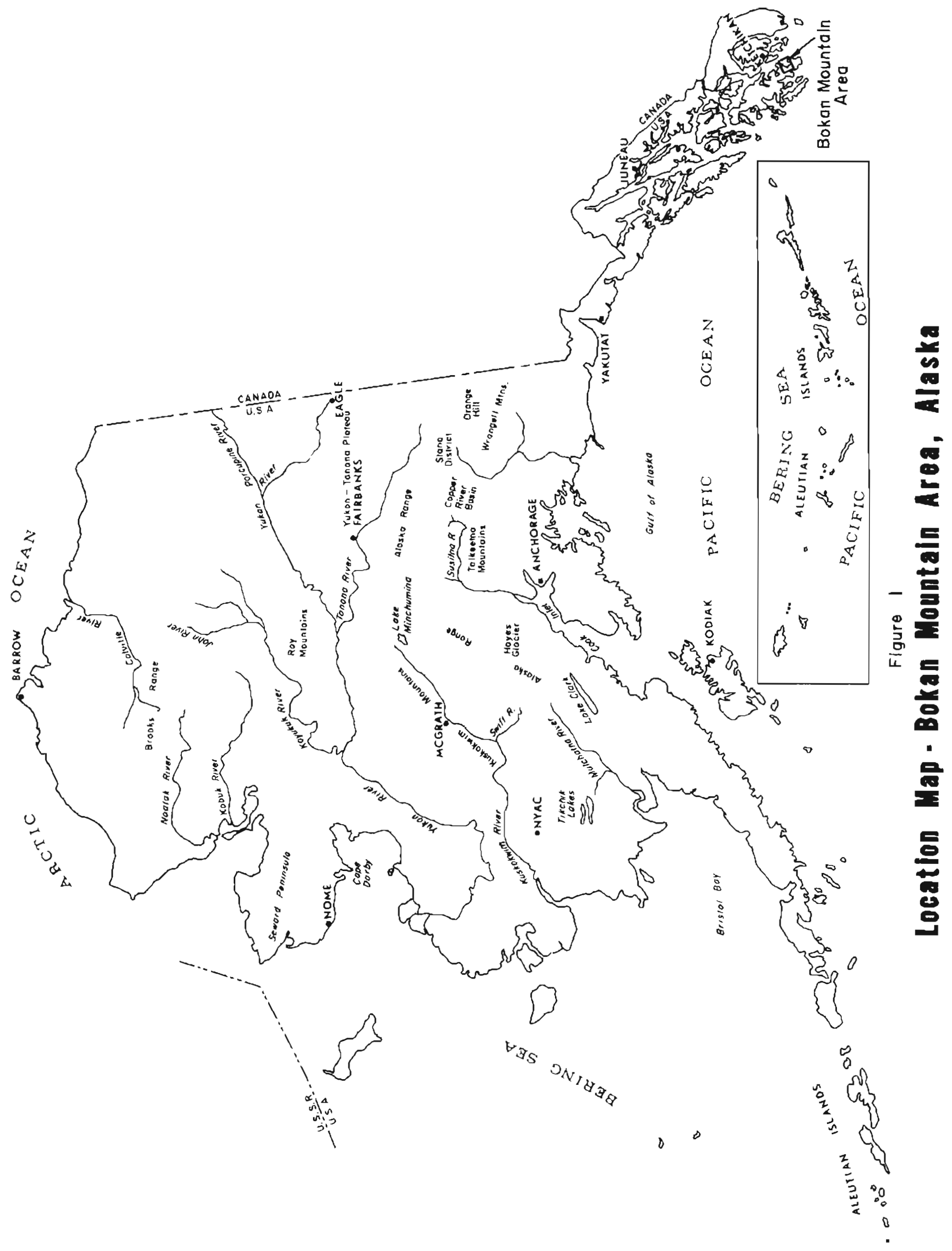




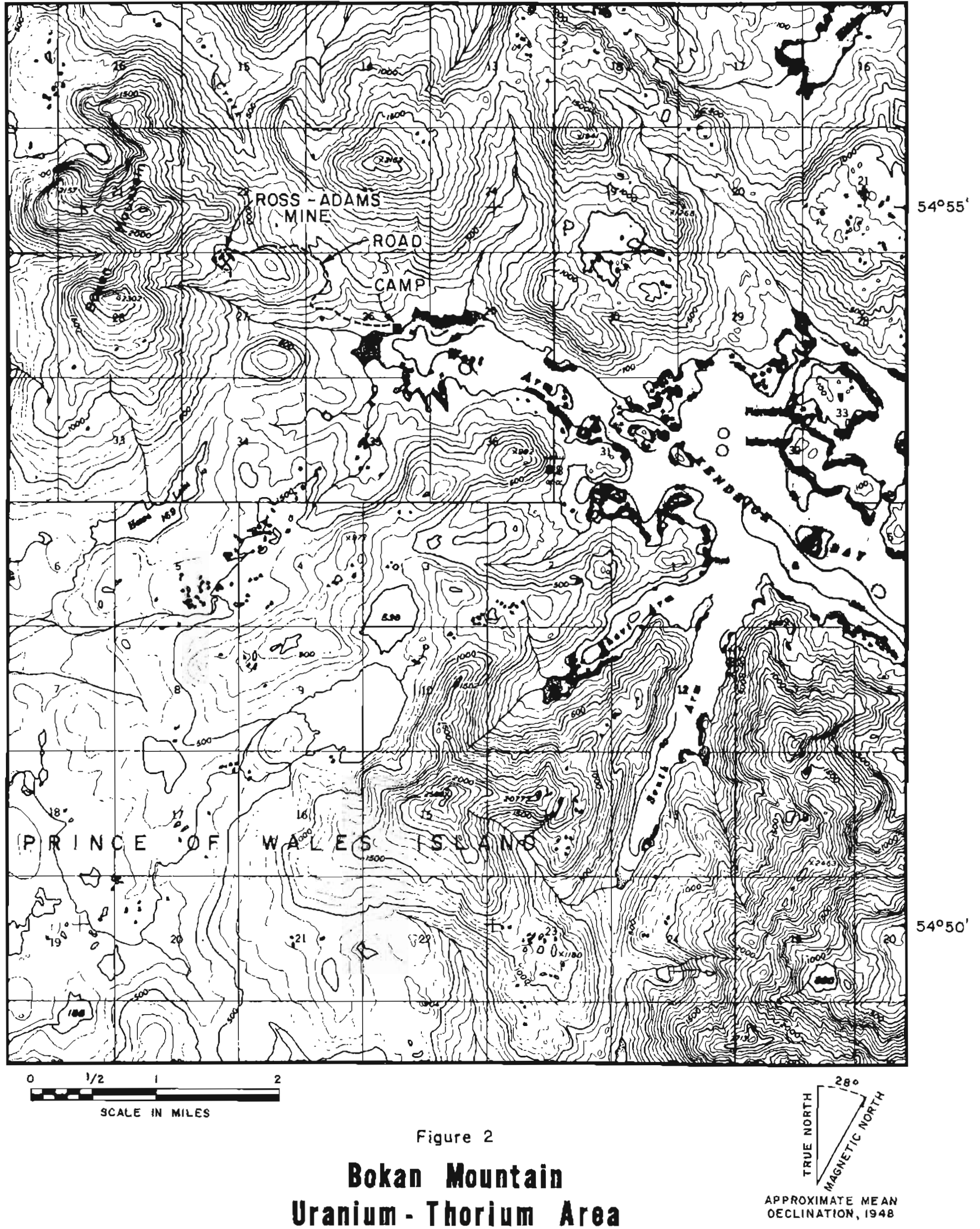




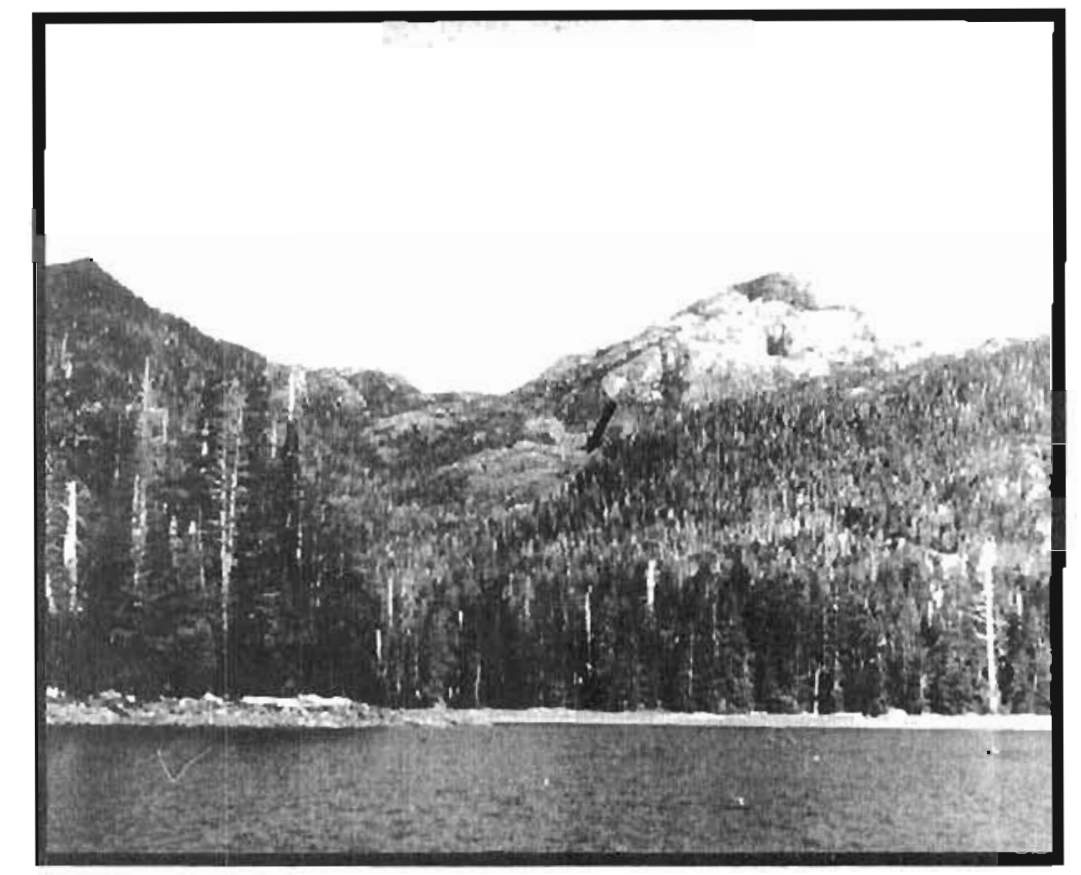
Flgure 3-- Bokon Mountaln from Kendrick Bay, facing west.
Arrow marks the locolion of the Ross-Adams mine.

PREVIOUS WORK

Larly regional geological reconnaissance was done by Wright and Wright (1908) and Buddington and Chapin (1929). Other pulslicitions contálining historical information on mining and the geological setting are lisced under REFLiRENCES.

The mist conplete published repurt on the Bokan Mountain uranium-thorlum area is by Mackevet (1963). It is accompanied by a geological map with a scale of 1:24,000. Much of the following description of geology and mineralogy of the Bokan Mountain area have been drawn from this report. Field work by Mackevett was done during the summers of 1.956, 1957, and 1958. Mining at the Ross-Adams mine up through that time had been limited to the shipping of 15.000 tons of ore prodiced from a erench approximately 400 feet long, 30 to 70 Eeet wide, and 30 feet deep. Jater a 500-foot tunnel was driven ar the 700-foot leve] Loward the ore body, and a raise connected the cunnel with the open pit at the 925-ioot elevation (figs $5 \& 6$ ).

Biogeochemical methods used for uranium prospecting in the western states have been developed by the U. S. Geological Survey (Cannon, H. L., 1956, 1957, 1960, 1964, and otikry). While the writer is not aware of any previous plant analyses for uranium in Nlaska, a report on Lead and zinc in plants in Southeastern Alaska (Shacklecte, 1960) compares metal contents of seven spectes. Another paper (Chapman and Shacklette, 1960) sumnarizos the average lead, zinc, copper, nickel, iron, and molybdenum content of several Aliskan plancs. Shacklette (1965) has discussed the assoctation of bryophytes wich mineral deposits in Alaska. Outside of Alaska, private companies have done extensive work in this field and a number routinely make botanical anaiyses for uranium in their own Laboratories. 
I10 vado of yłnos

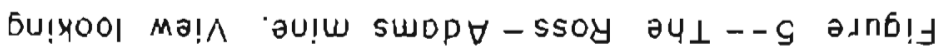

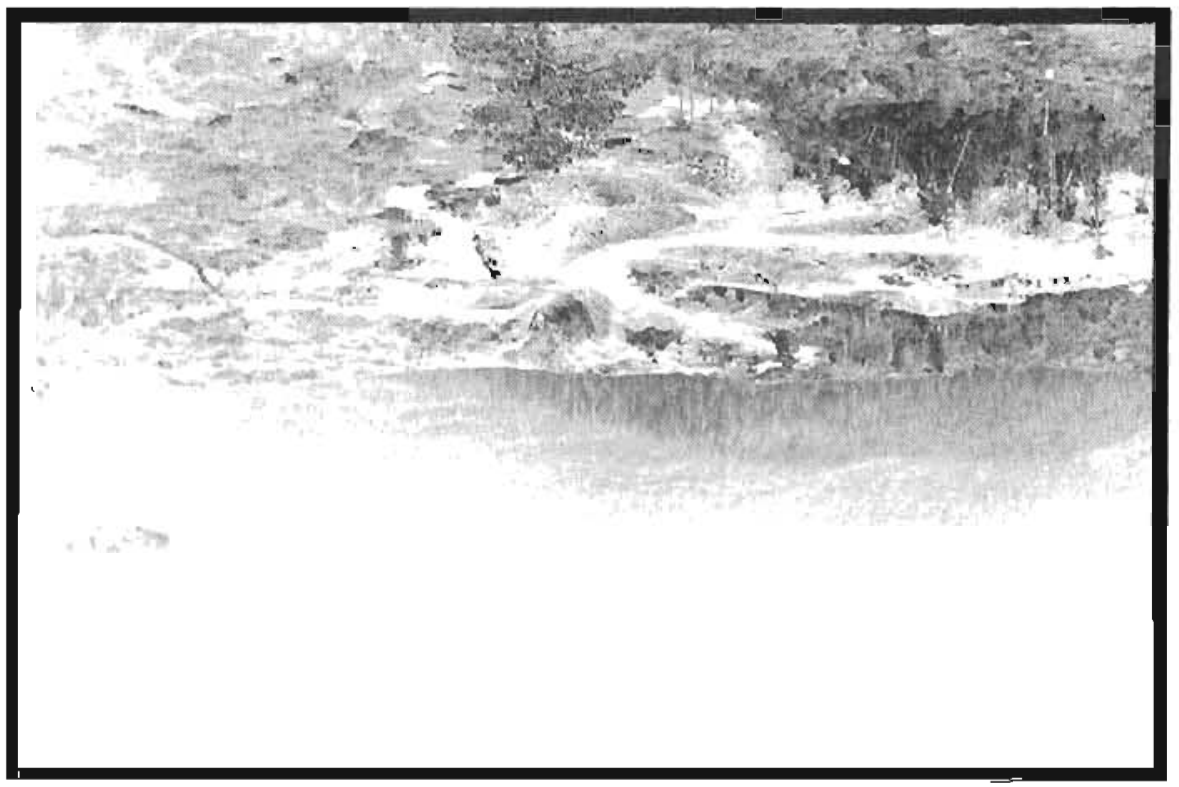

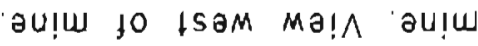

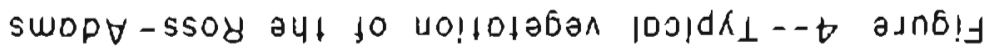

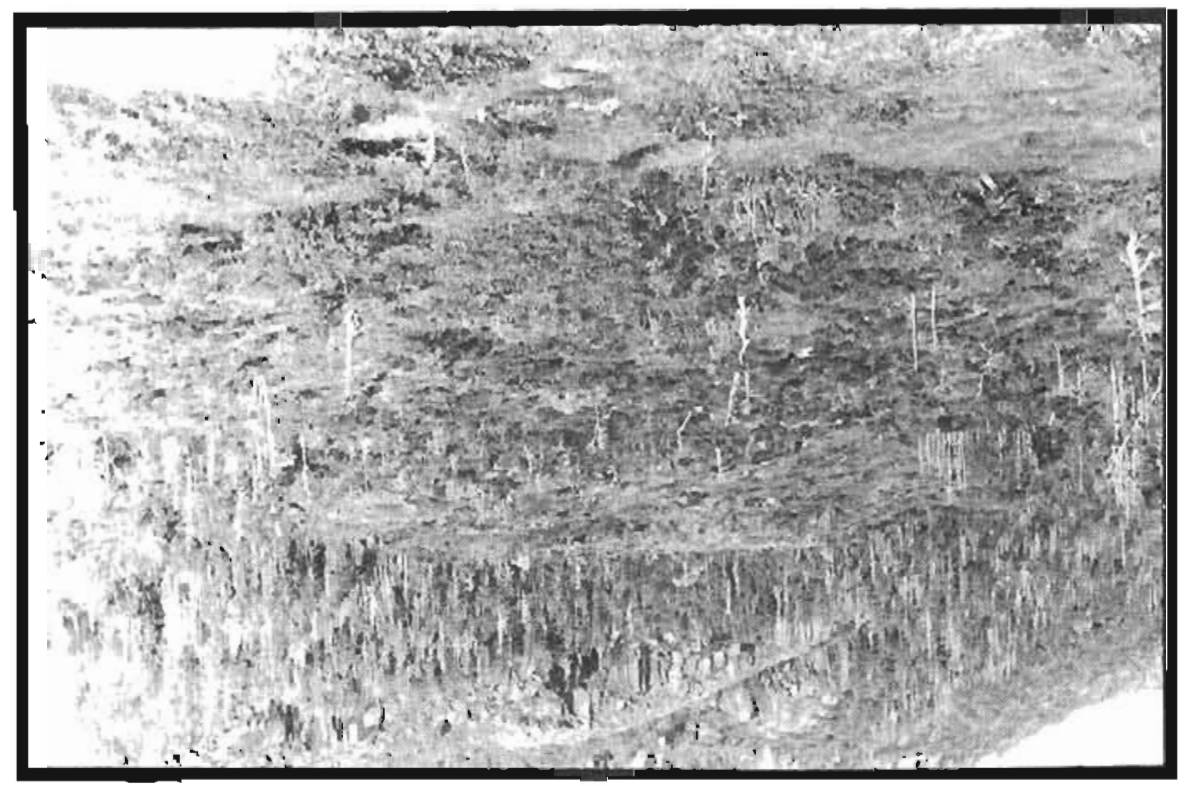


A C K N O W L E D C E M E N T S

The writer wishes to express his gratitude to Newmont Exploration Limited for permission to conduct the biogeochemical test project on their property. He is indebted to Mr. B111 Mounts and Mr. Vivian Vellet of Newmont for their generous assistance and hospitality at the Kendrick Bay camp. Appreciation is due Mr. R, L. Dotson, who holds clatms in the area, for his cooperation during the study,

Samples were analyzed by Union Carbide Corporation at their Grand Junction, Colorado laboratory. This service was a great contribution to the project, Thanks are extended to Mr. P. E. Galli, Union Carbide geologist, for his assistance in handling sanples and arranging for analyses.

G L N E R A L G ËOLO GIC S E T T I N G

Southeastern Alaska is a subprovince of the Western Cordtllera tectonic belt. The principal features of the province are the Coast Range Batholith and the outlylng subsidiary intrusives. The hatholite is conplex, consisting of a vartety of lgneous rocks of various ages.

Marine sediments and volcanics deposited In Paleozolc and Mesozolc euogeosynclines on the western side of the orogente belt Eormed thick sequences, cotaling possibly 50,000 feet. The oldest dated rocks are Ordovician and Early Silurian (Brew, Loney, and MufEler, 1966).

Deformation and plutonic activity during the Nevadian orogeny have reglonally metamorphosed the rocks and creaced many large-scale faults with lateral movements to more than 50 miles. A conspicuous north-trending linear fault pattern can be seen in many fiords and straits. A number of fault zones contain mineral deposics (Twenhoffel and Salnsbury, 1958). A large vertical fault apparently has controlled the development of the South Arm of Kendrick Bay. Both primary and secondary foints are common. Primary joints, interpreted as being the result of rapid cooling, have localized many of the pegmatite dikes in granite.

Metamorphism on the west side of the Coast Range Batholith has created gneisses which grade westward into the schists, phyllites, and less metamorphosed rocks on the islands of Southeastern Alaska. The strike of most of the bedded rocks and the general grain of the majox structures is northeastward. 


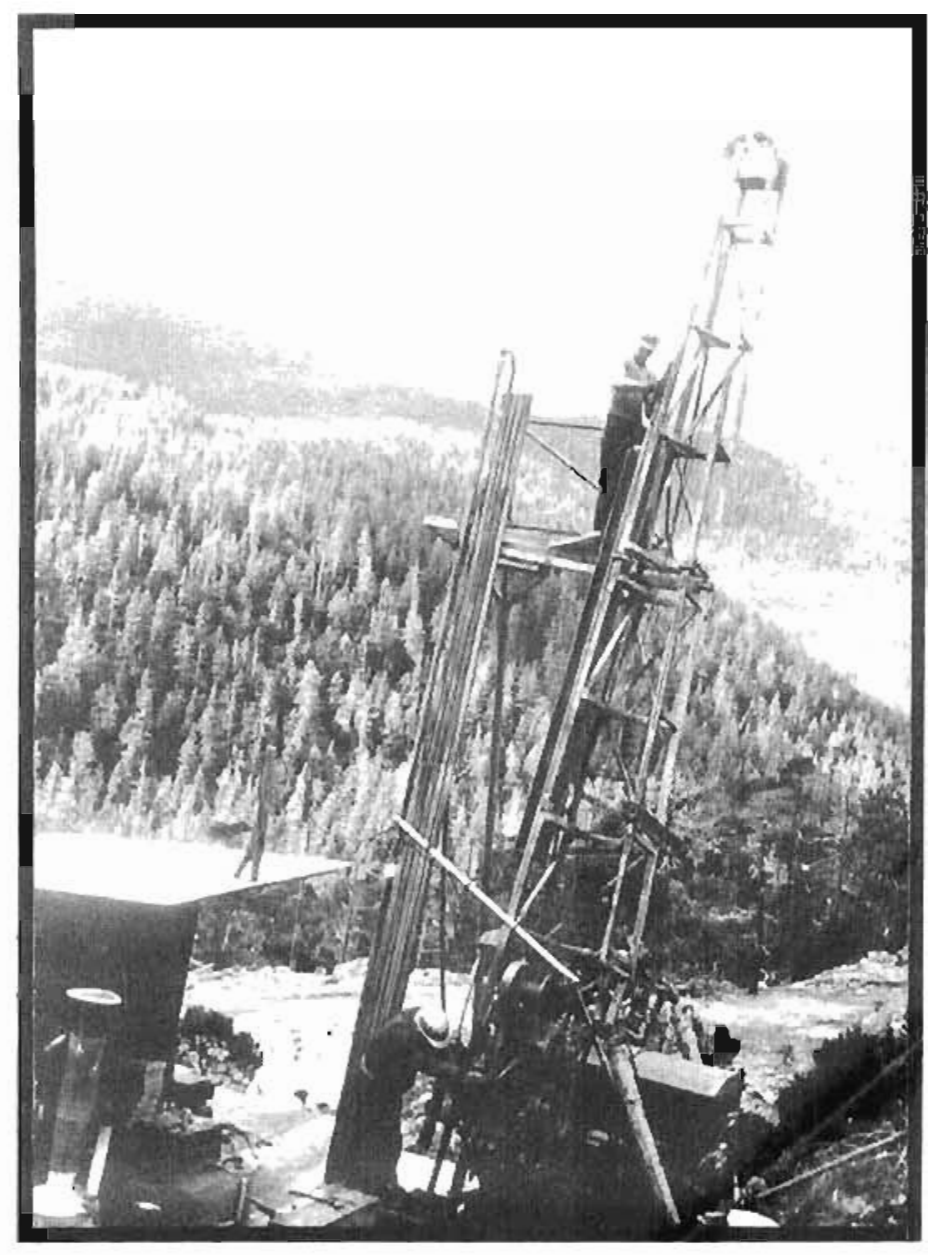

Figure 6--Core drilling of the Ross-Adams mine. View southwest of mine. 
$M I N I N G \quad O E \quad N O N R A D I O A C T I V E$ T A T E R I A L S

The history of mining in Southeastern Alaska goes back ro 1867 when a Russian first mined copper on Prince of Wales Island near new Kasaan. The region contains many old mines and prospects and a wide variety of minerals. The most important deposits are closely related to plutons and structural features of early Mesozolc and early Tertiary age. So far, very few large mineral deposits have been found in the main Coast Range Intrusions.

Southeastern Alaska's lode mining has yielded 6,2 million ounces of gold, $3.3 \mathrm{mill}$ ion ounces of silver, 37 million pounds of copper, 48.3 million pounds of lead, 111 thousand pounds of $21 n c$, and 14 thousand pounds of platinum group metals, mainly palladiun (Kaufman, Alvin, 1961). Ocher ores and potential ores are antinony, barite, garnet, tron, molybdenum, titanium, nickel, and tungsten.

In the bokan Mountaln area, copper and gold deposits were staked during the early 1900 's at several localities between Mclean Axm and Mallard Bay. The Polson and Ichis copper and gold prospects are just south of McLean Arm, nine miles southeast of the Ross-Adams mine. Ores there are locallzed in quartz-calcite-barite veins in a serles of fault zones, Pyrite, chalcopyrile, hematite, chrysocolla, and traces of bornite and gold have been found. Gold was once produced from auriferous pyrite at the Nelson and Tift mine, a mile west of the mouth of McLean Arm. The ore formed a small lens in calcareous rock that has since been mined out.

Tron claims have been staked in the southern part of Prince of Wales Island where magnetite occurs with hornblende concentrations in diorlce and pyroxenile.

G EOLOGY O I T T E BOKAN MOUN T. A I N

URA N I UM- THORIU U A R E A

BLDROCK

Radioactive minerals of the Bokan Mouncain district are associated with a small peralksLlue granite stock of Mesozoic age which has tntruded an older monzonite pluton. AccordIng to the Shand classification, peralkaline granite ts an igneous rock division fa which the molecular proportion of alumina is less than that of soda and potash comblned. Potassium-argon and lead-alpha measurements Indicate the Bokan Mountaln grantle to be late Jurassic or early Tertiary in age and the older pluton to be early Paleozoic, probably ordovician (Lanphere, M. A., Mackevett, E. M., and Stern, I. W., 1964). The pera1kaline granice stock is roughly circular and about two miles in diameter. This rock 1s well exposed on the steep slopes of Bokan Mountain. 
Slate of Devonian age extends around three sides of the central stock and along the contact between granite and monzonite, At other places the slate is separated from the granite by a strip of monzonite. Paleozoic greiss, schist, amphibolite, marble, and calcic hornfels lie north and west of the slate. South and east of Bokan Mountain the rocks are predominant]y quartz monzonite and quartz diorite, but other plutonfc rocks $i_{n}$ the area are pyroxenite, gabbro, and syenite. A variety of dikes, largely aplite, pegmatite, and andestte, are widespread. Radioactivity is frequently encountered in the aplite and pegmatite dikes.

Peralkaline Bokan Mountain granite is the rock of primary interest. It is the host for most of the uranium-thorium depostis, and underlies most of the material sampled for chis project.

This granite is unusual and has not been reported from any other locality in Southeascern Alaska. It is characceristically high in quartz and sodlum-bearing mafic minerals. Many different textures have been noted and grain size varies from fine to coarse. It is generally Ilght gray to white and speckled with about 10 percent dark minerals. Acmice and rlebeckite are characteristic, and each is presenc in amounts from one to twelve percent. Accessory minerals are chiefly zircon, uranothorite, pyrite, xenotime, fluorite, cordierite, and magnetite. Unusual amounts of the minor elements, uranium, thorium, yttrium, lanthanum, niobium, cerium, and other rare earths are present.

Some of the dikes within the area, especially aplite and pegmatlie, genetically related to the Bokan Mountain granite are interesting because they contain uxanium, thor 1um, zirconium, and niobium. These dikes are believed to have crystallized from a volatilerich fluid during a late intrusive stage. Quartz-rich aplite dikes are up to 1000 feet long and 10 feet wide. Pegmatites are less than 4 feet thick, bur are traceable for as much as 3000 feet. They are poorly zoned and contaln scattered dark uranium or thorium minerals. Other dikes in the area range in composition from diabase to rhyolice and form a complex assembiage.

URANIUM-THORIUM DEPOSITS

Most of the uranium and thorium minerals in the Bokan Mountain district are primary types and are believed to have formed by hydrothermal solutions during Tertlary time, The principal radioactive minerals there are uranochorite, uranoan thorianite, and uranintte. Phosphates, niobates, and complex sillcates are present in minor amounts and carry some uranium or thorium.

Four types of deposits in the Bokan Mountain area have been described by Mackevett

1. Primary segregation of uranium-thorium minerals in a late stage of the peralkaline grantle magma and subsequent hydrothermal deposition, This type occurs at the Ross-Adams mine.

2. Syngenetic deposits in pegmatice and aplite dikes,

3. Epigenetic hydrothermal deposits, chiefly open-space filling, but includes some replacement.

4. A deposit formed in clastic sedimentary rock by filling of the interstices at the Cherl No. 1 prospect, 
ROSS-ADAMS MINE

The initial uranium discovery in the Bokan Mountain area was made in 1955 by Don Ross and Kelly Adaus using an airborne geiger councer. A total of 60,000 tons of ore averaging almost one-percent of both $\mathrm{U}_{3} \mathrm{O}_{8}$ and thoriun has been produced by vartous operators. The mine was closed in 1964 after fulfilling a contract with the Atomic Energy Commission. An effort to reopen it is pending results of core drilling and ownership negotiactons. Newmont Lxploration, under an agreement with Standard Metals, is currencly evaluating the property, which covers appcoximately 500 acres. Drilling has proven the extenston of ore beyond previously known linits. The internal structure of granice at the mine has been found to be much more complicated chan was suspected bef̃are Newmont's work.

The ore body is irregular, but plunges generally southward, The percentage of uranlum minerals decreases gradually outward from a high-grade zone, and ore limits are fndefinite. Two steep intersecting faulcs striking N70W and N80E are exposed at the south end of the open pit. These faults cut the ore and displace it to the south. On the largest fault, the writer observed slfckensides, which indicate d few feet of recent lateral movenent. In addition, many smaller faults and joints are present throughout the mine.

Figure 7 shows lineations evident on dertal photos in the Ross-Adams mine area. These probably represent high-angle joincs and faults, Intersections occur that might be loci of crushed zones favorable for mineral deposits. Under the microscope 1ron-stained fractures can be seen radiating from the ore ininerals and from reticulating veinlets along cleavage planes in the feldspars.

The ore body mined in the open pit originally contained a "core" of high-grade ore which averafed over $0.5 \% \mathrm{U}_{3} \mathrm{O}_{8}$. $\Lambda$ large portion contalned ore running $7 \% \mathrm{U}_{3} \mathrm{O}_{8}$, and pods contained up to $3 \% \mathrm{U}_{3} \mathrm{O}_{8}$. T'welve samples anlyzed by the U.S.G.S. ylelded from 0.18 to $3.2 \%$ chemical uranium. High-grade ore can be distinguished by its dark color due to the presence of associated hematite in the granite. The "core" was enveloped by a zone of lower-grade ore between 2 and 20 feet thick that averaged less than $0.5 \% \mathrm{U}_{3} 0_{8}$. Information is not available on the ore mined later by underground methods.

Two radiometric surveys by the writer shown in figures $8 \& 9$ give readings in mj.1liroentgens per hour obtained with a scintillometer in the main open pit and in the short tunneJ. at the upper level of the mine. Figure 8 shows readings recorded with a geiger counter, both in the maln upen pit and in the lower tunnel. The gelger counter readings are considerably lower overall than the scintillometer readings, due to differences in instruinent sensitivities. The background in both cases averaged about 0.02 milliroentgens per hour at the surface. The highest radioactivity in the entire area, based on geiger counter readings, was at the widest part of the lower tumel where the short crosscuts connect. This zone is highly broken and sheared.

\section{Mineralogy}

The ore minerals are difflcult to identify but almost all are prlmary. They occur both as scattered grains throughout the peralkaline granite and in numerous thin $(0.1$ co 0.8 mm) vein.lets, Anhedral to euhedral grains up to $2 \mathrm{~mm}$ wide are rypical, The dominant ore minerals are uranothorite (uranium-bearing thorite) and uranoan thoriandte (uraniunbearing thorianite). Coffinite $\left(\mathrm{U}\left(\mathrm{SiO}_{4}\right)(\mathrm{OH})_{4}\right)$ is found in minor amounts, Other vein minerals accompanying the ore minerals are abundant hematite and calcite, and lesser amounts of fluorite, pyrite, hydrous iron sesquidoxides, galena, quartz, clay minerals, and chlorite, 


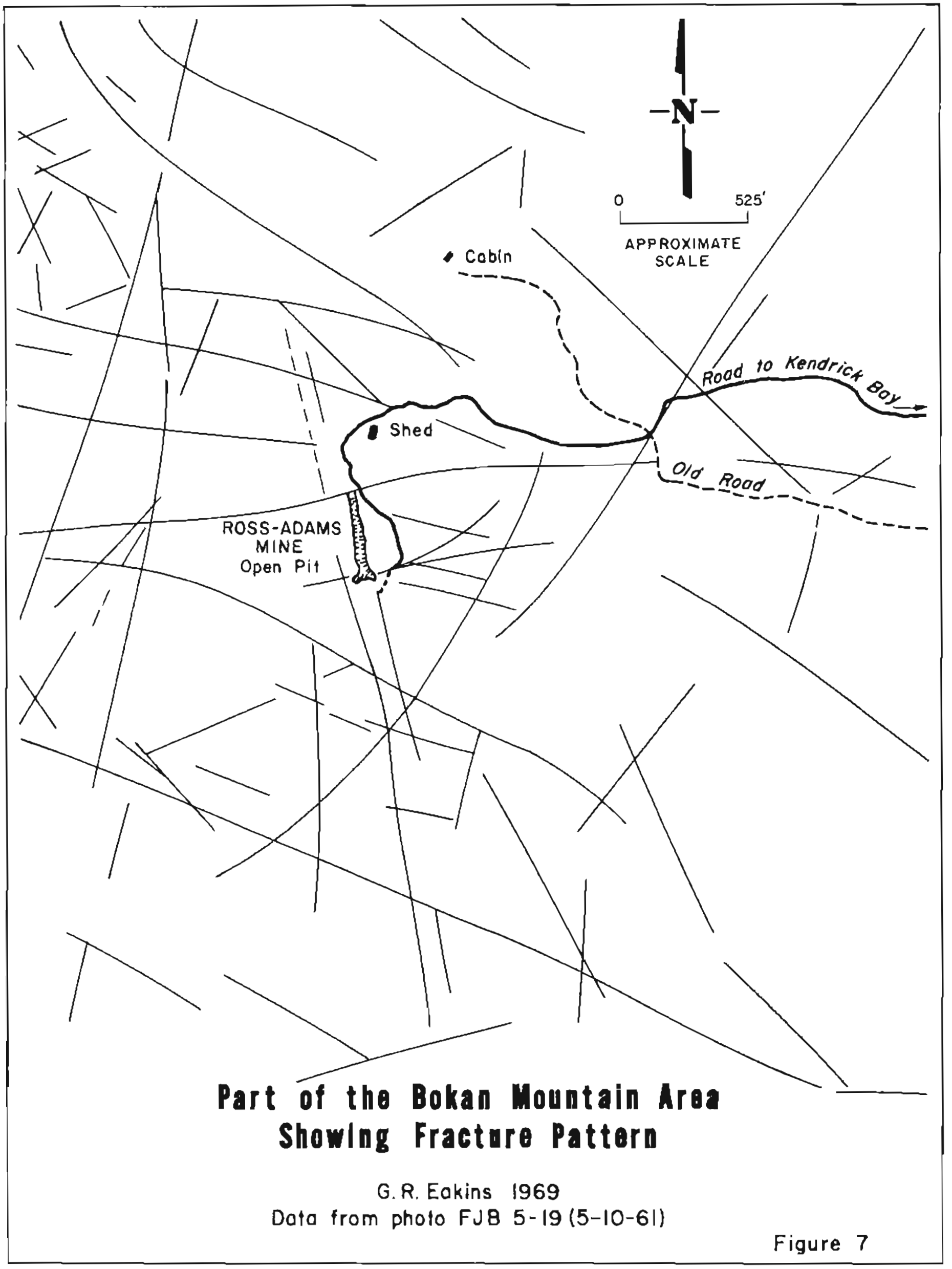




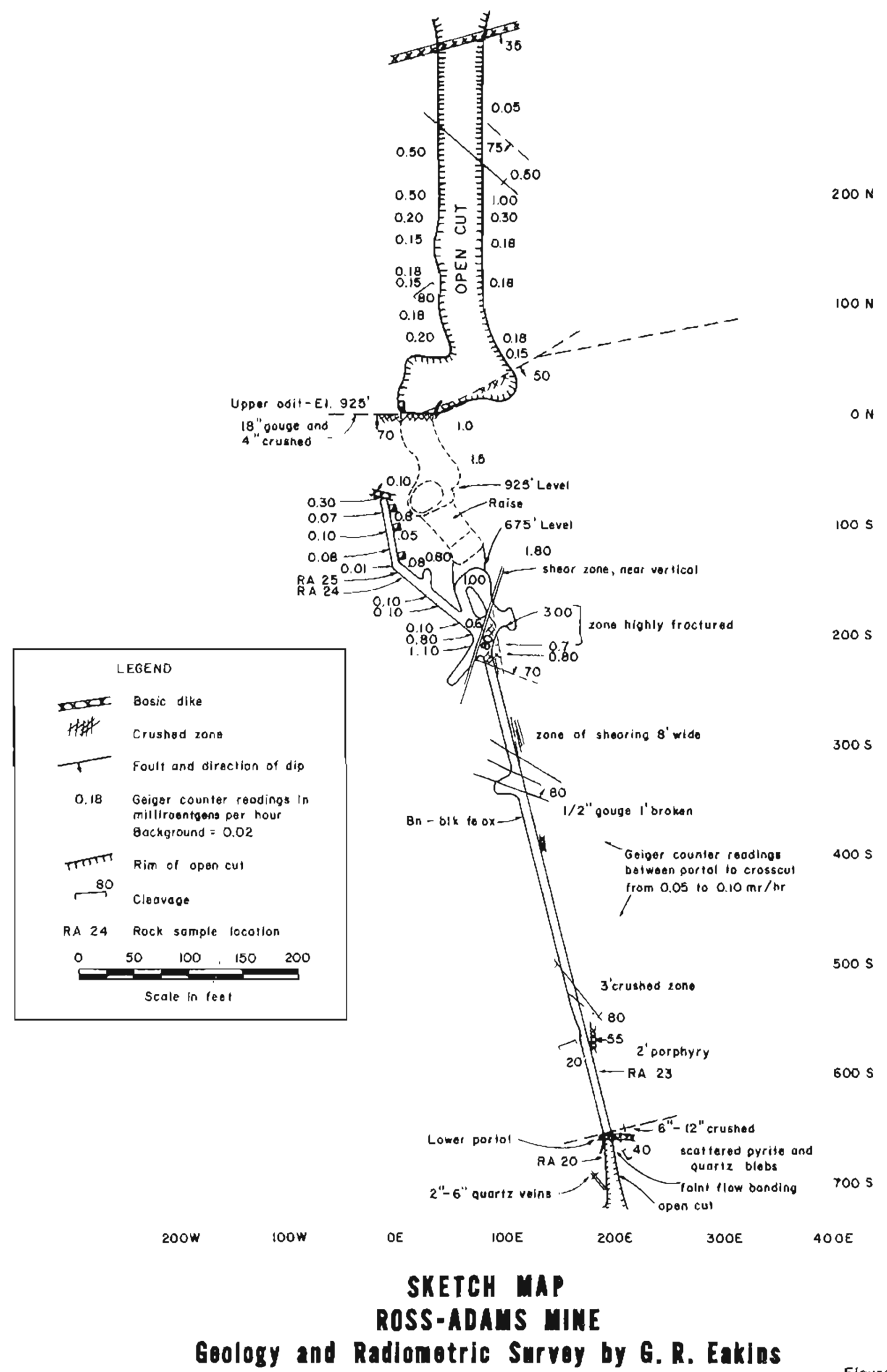

Figure 8 


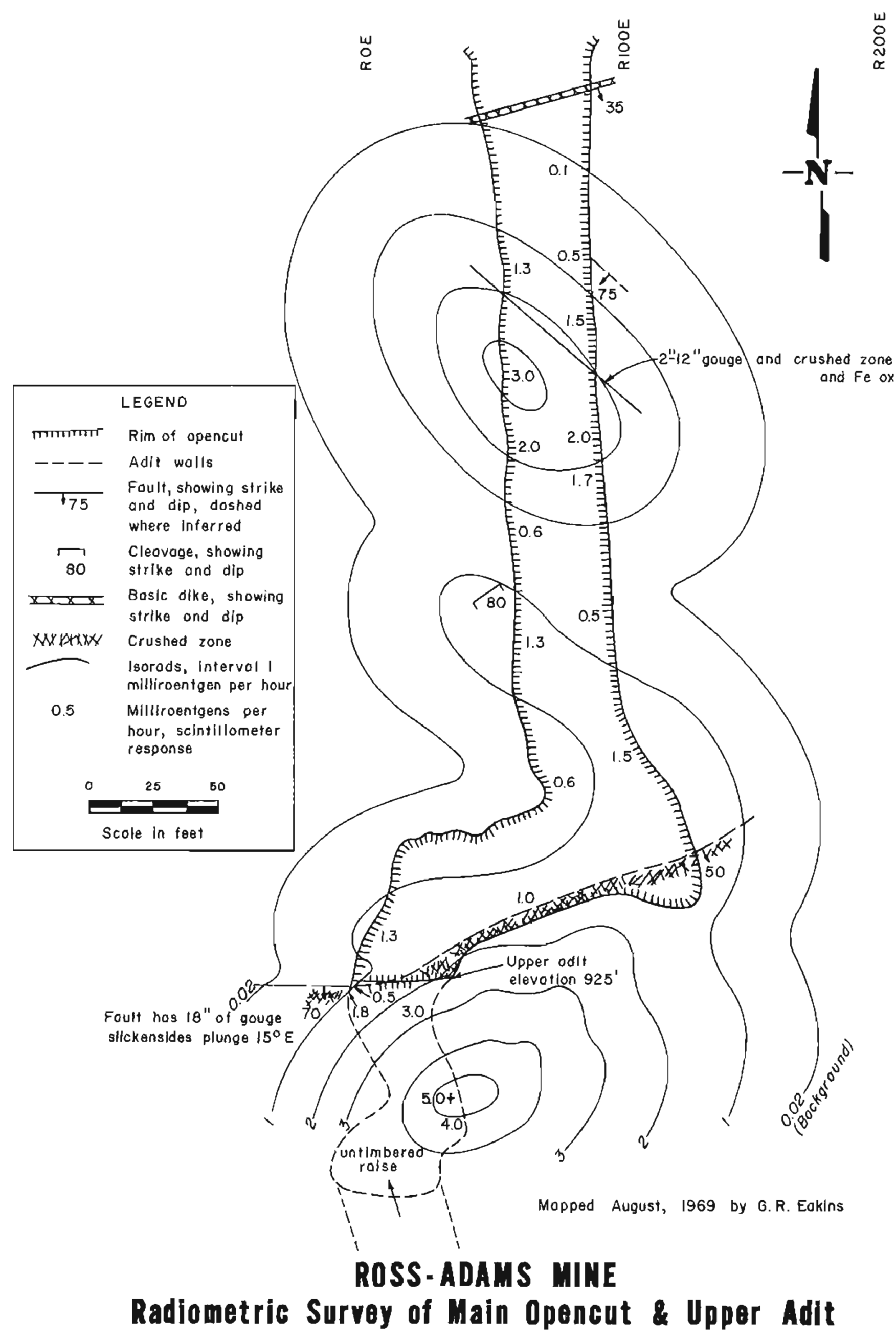

T $300 N$

T200N

TIOON

TON

TIOOS

Figure 9 
While there is no sharp boundary between the ore and the host granite, the ore contalns slightly more ixon, lead, aluminum, zirconium, ritanium, magnesium, calcium, manganese, and arsenic, but less quartz and potassium, than the surrounding rock. Most of the ore is out of radioactive equilibrium, but the thorium combines with the uranium in such a way to give the effect of apparent equilibrium,

Other uranium-chorium minerals have been found in small amounts at some ocher prospects in the area. These include uranintte, uranophane, allanite, possibly davidite or brannertte, and ellsworthite. Only minor amouncs of secondary uranium minerals have been reported from the koss-Adams property. These are gummite, sklodowskite, betauranophane, bassetite, and novacekite. The scarcity of secondary uranium minerals is undoubtedly due to thelr solubility and the heavy rainfall in the area.

Ore Genesis

Uraniun-thorium mineralizacion at the Ross-Adaus mine is believed to be hydrothermal in origin. It apparently occurred subsequent to the crystallization of the peralkaline granite, and probably was factlitated by a complex fracture system. Tuttle and Bowen (1958) theorized that vapor pressure in crystallizing granite could exceed the overburden limit causing fracturting of the roof with a resulting sudden drop in pressure and rapid crystallizacion. Sucin a process might have alded in creating a system of microfractures into which the Late stage ore ac the Ross-Adams mine was emplaced. Later movements offset the ore body slightly.

OTHER CLAIMS AND PROSPECTS

Claims and prospects in the area are numerous near altered dacite dikes in albitized zones along che margin of the peralkaline granite. Others are on small pegmatite dikes within the granite. Most claims are only slightly explored, One prospect was located with the incent of mining fluorite,

The Atom-Marierta clains are about 1600 feer east of the Ross-Adams mine (fig 10). Shallow pits there have exposed radioactive material in shear zones in the older sedimentary and metamorphic rocks near the contact with the Bokan Mountain Granite. Sample locations $27-30,59,60,61,65$, and 66 are on the Atom-Marietta claims.

Ocher claims cover weakly radioactive zones scattered In the Bokan Mountain Granite. The "I and L" group of claims adjoin the Ross-Adams mine property. These claims are about 1000 feet north of the Ross-Adams mine at a slightly higher elevation (fig 10 ). Most of the soil and vegetation there has been stripped by bulldozer work and natural erosion. Here radioactive minerals occur in pegnatites and along the northwest trending Hollenbeak vein.

Outside the peralkaline granite stock, weak anomalies occur on prospects near Gardner Bay about eighr mlles southeast of Bokan Mountain. The anomalies are in pegmatices. Rather weak anomalies have been found in altered andesite dikes cutting syentte near Stone Rock Bay about three mlles farther south from Gardner Bay, 


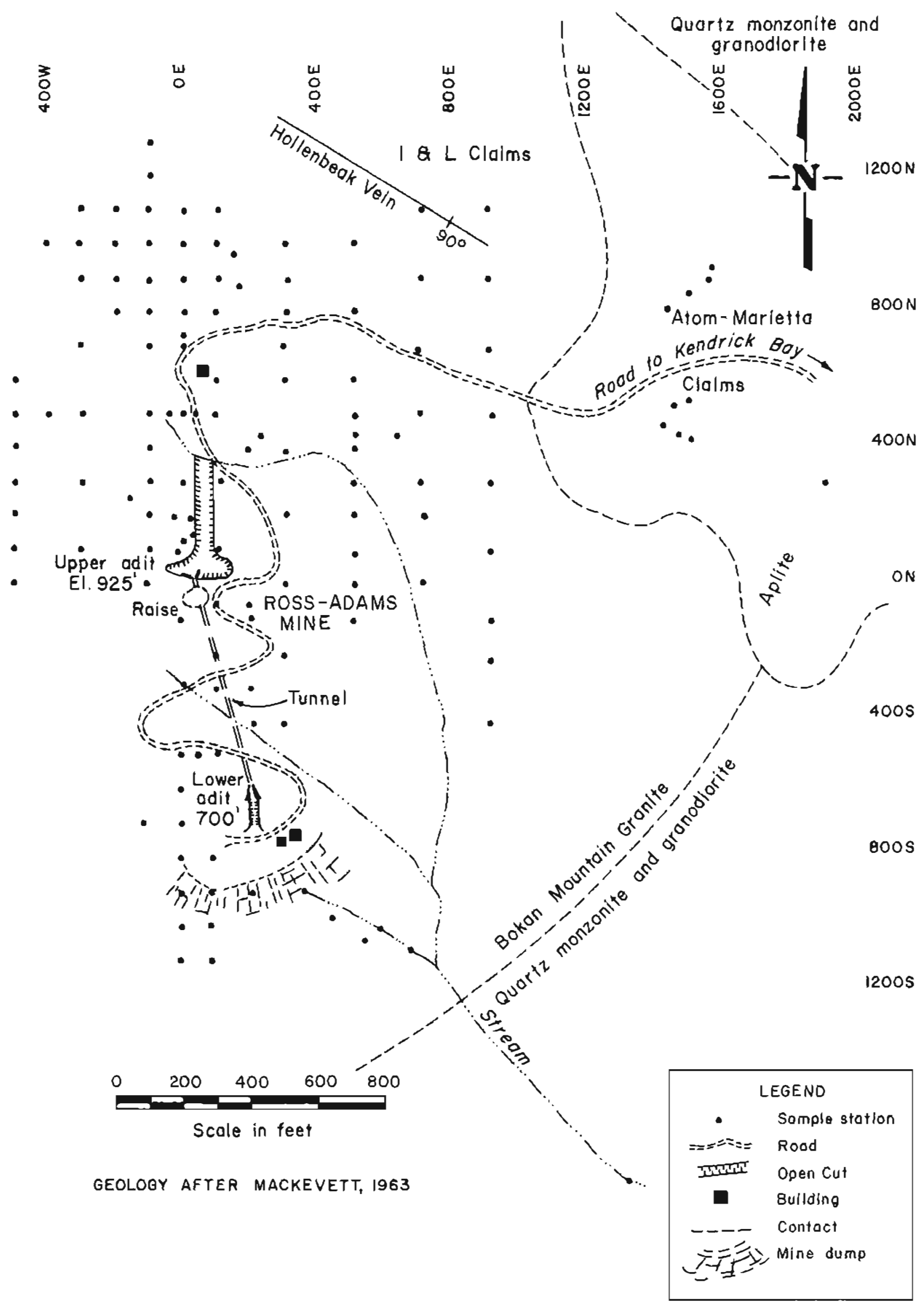


B I O G EOCHEMICAL PROSPECTING METHODS

Two different botanical prospecting methods have proven effective in locating uranium ores in covered areas where radiomercic instrumencs have falled.

The indicator plant method of botanical prospecting is based on the principle that certain plant species indicace the presence of abnormal anounts of radioactive elements in soil or ground water associated with weathering mineral deposits, For example, the selenium indicator plants of the Astragalas genus have been used successfully to locate uranium in the Colorado Plateau (Cannon, H. L., 1960), R, L. Dolson, who has been prospecting on Bokan Mountain, has pointed out that the blue flower, lupine, appears to favor the uranium-rich soil in this area, Plant assemblages, or sometimes the lack of them, over known ore deposits conpared with assemblages over nonmineralized areas is required for the systematic use of the method.

The biogeochemical method of botanical prospecting involves the chenical analysis of ashed plant material. Deposics of urantum, zinc, tungsten, tin, arsenic, copper, and vanadium have been discovered in this manner. Preliminary plant inventories and analyses are needed to deternine which species will best serve to locate particular elements and to establish their normal or background values. The usefulness of plant analyses depends upon finding certain plants of wide discribution which during growth accumulate anomalous amounts of indicator metals. Plant analyses in Grand County, Utah, showed that sulfur, selenium, arsenic, and molybdenum are concentrated with uranium in that area (Cannon, H. L., 1964). A variecy of plants, ránging fron small bushes and flowers to trees of both contfer and broadleaf types, may be used with varying degrees of success (Cannon, 1960). Lichen and algae also have been found to accumulate uranium in anomalous amounts. A uranium content of 1 part per million or more is frequencly considered ro be anomalous in the Colorado Plateau region (Froelich, Albert J, and Klelnhampl, 1960, p 59).

Relicable comparison of absolute analytical values can be made only if the samples are collected in a consistent manner and are collected from tdentical parts of the same plant species. In general, plants with deep roots will serve better than those with shallow roots, Leaves may show greater metal concentrations than the twigs, but both parts can be used. Dead branches of lrees in the La Ventana Mesa uranium area, New Mexico, yleld more uranium in ash than do live branches (Cannon, H. L. and Starrett, W. H. 1956), Depth of root penetration, anount of moisture in the soil, and depth of the mineral deposit are variables which influence the effectiveness of the method, Fracture patterns, ground water movement, and topography should also be considered when interpreting the results of a botanical sampling program.

Geochemical prospecting for uranium by stream sediment analyses has not been considexed vexy useful because of the high mobility of the $U_{6}$ ion (Cohen, Brooks, and Reeves, 1969 ). However, Limited stream sediment sampling by this writer at Bokan Mountaln appeared to be effective. 
Plants selected for sampling depended largely on thets availabillty. The choice over much of the area was linited to small, stunted evergreens. The species most prevalent were lodgepole pine, western cedar, western hemlock, and common juniper. Trees are larger and denser away from the mine.

Sampling was conducted principaliy over the Ross-Adams mine propercy, where the presence of uranium ore is known. Samples were taken matnly on a grid with spacings of 100 or 200 feet (figs 10 \& 12). Sanples of the various plants selected were collected within a radius of 30 feet of the sample station. Spot sampling was done at some of the outlying prospects.

The principal sample area and grid system extend approximately 2500 feet from north to south and 1600 feet from east to west. Bare bedrock 1s exposed over much of the area and soil is generally only a few inches thick. In the more heavily wooded parts around the margins of the sampling area, the soil was as much as two to four feet thick. The surface around the mine is humnocky and the slopes fairly gentle. Slopes steepen to $20^{\circ}$ in marginal areas. Runoff is rapid during periods of rain, and small temporary streans abound (fig 11).

Conditions which make the area less than tdeal for test sampling are variable but are generally (1) small thickness of the soil, (2) the shallow root systems of the plants resulting from thin soil and heavy rainfall, (3) the highly variable distribucion of the plants, and (4) the posstbility of contamination from surface mining operations. However, the choice of areas containing a uraniun deposit and known geology was very $11 \mathrm{mit}$ ted.

The numbers of samples of all types were as follows:

$\begin{array}{lr}\text { Algae } & 13 \\ \text { Blueberry } & 19 \\ \text { Juntper } & 19 \\ \text { Living lodgepole pine } & 88 \\ \text { Dead lodgepole pine and burls } & 22 \\ \text { Miscellaneous plants } & 13 \\ \text { Mulch and sol1 } & 41 \\ \text { Spruce } & 41 \\ \text { Stream sediment } & 9 \\ \text { Western cedar } & 108 \\ \text { Western hemlock TOTAL SAMPLES } & 48 \\ & \end{array}$

Plant samples were taken by cutting 6 to 10 tnches of the branch tips, including 1eaves, needies and cones, and placing the material in No, 8 paper grocery bags, Because of almost constant rain during the sampling, tearing of bags was a major problem. However, porous bags are required so that samples eventually can dry. Plastic bags are not recommended because plant material will rot if stored in air-tight containers, The welght of the samples ranged from four to eight ounces. Elght ounces or more are preferred in order to have plenty of ash for analyses.

Mulch or humus, which includes accumulated plant material on the ground in various stages of decomposition, has been known to show anomalous metal content over mineralized areas (Ginzburg, 1960, p 233). Therefore, mulch was included in the sampling program. Material was taken from near the surface, Just beneath the moss cover. These samples unavoidably contained live moss, grass roots, and soil. 


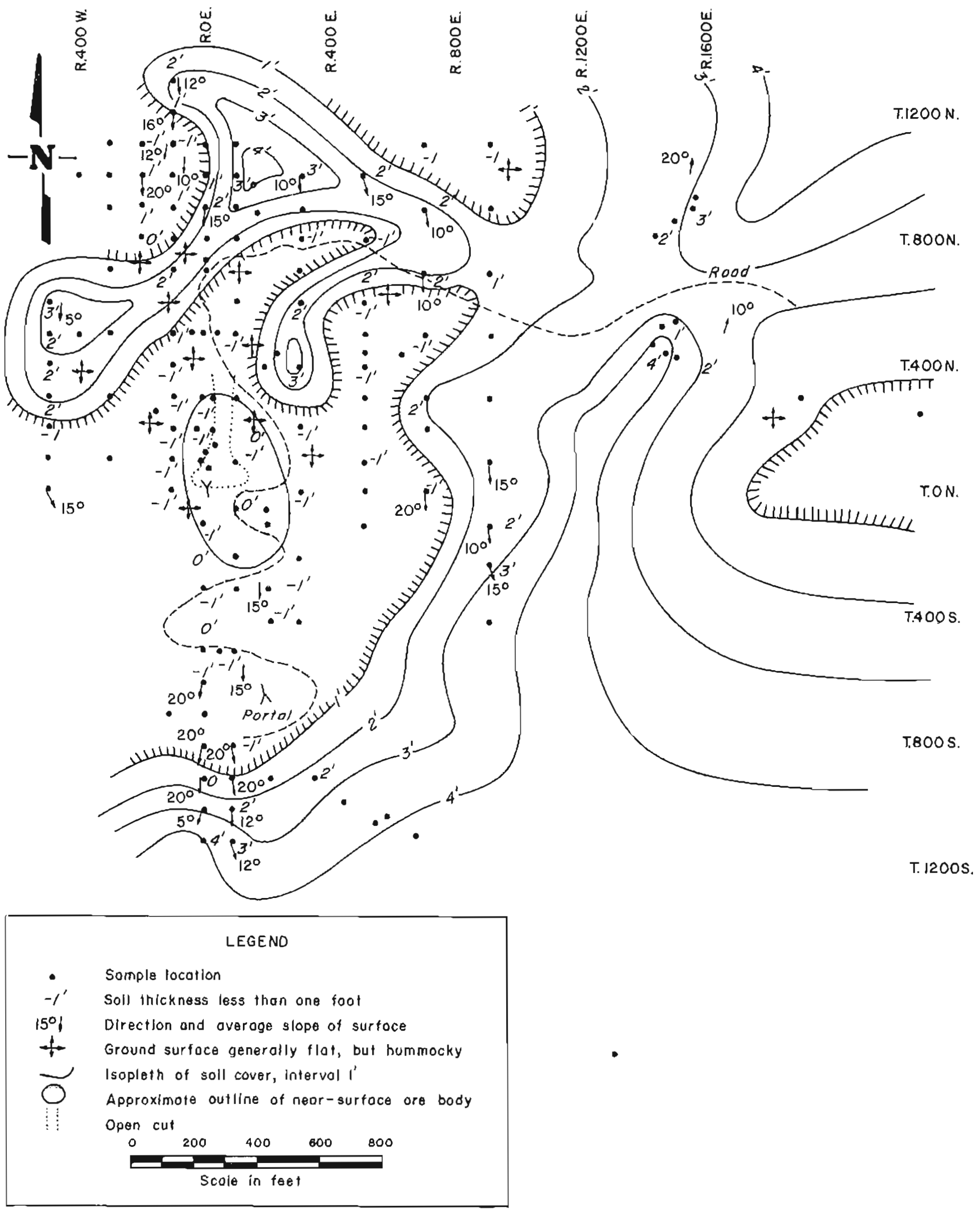




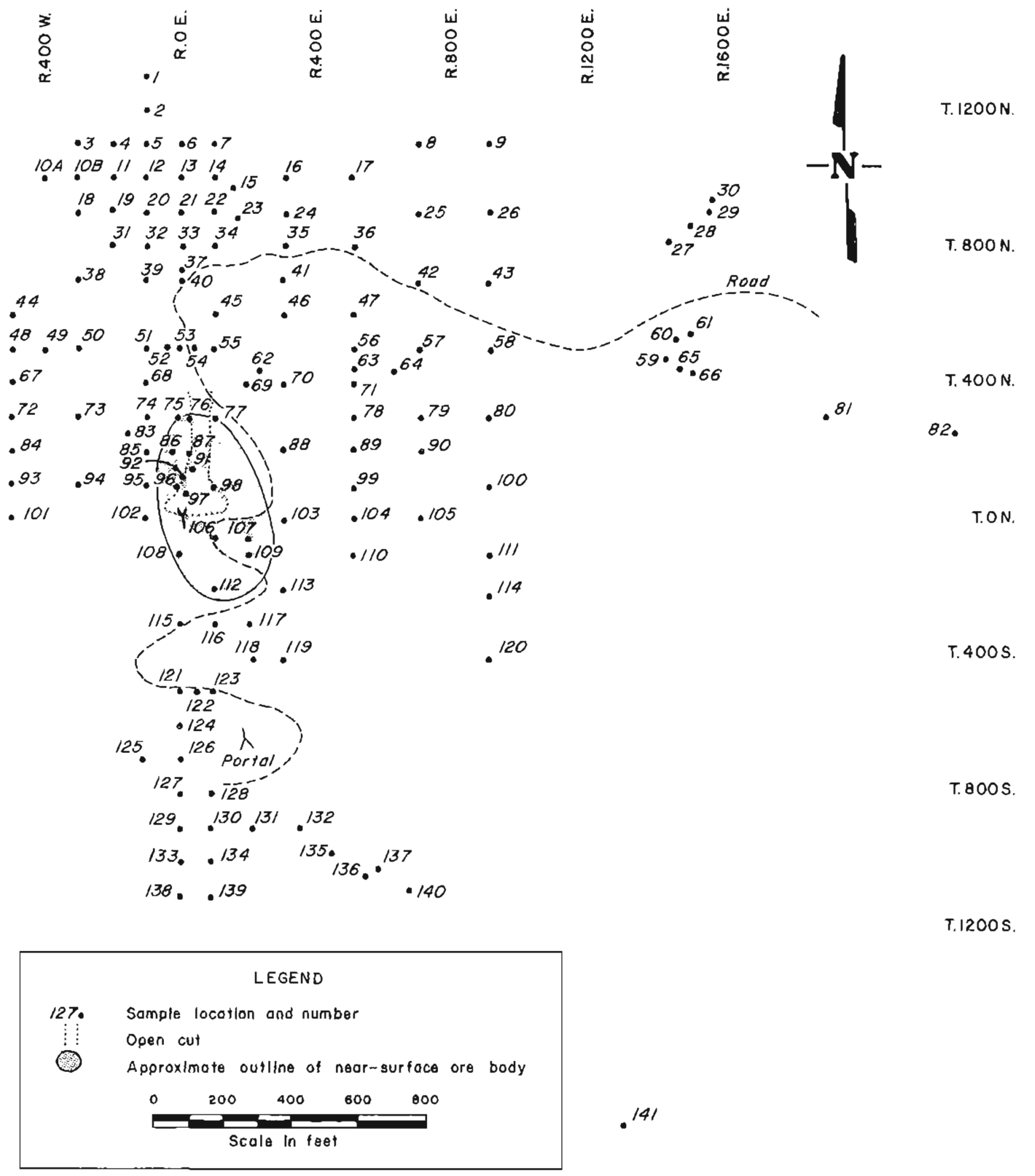

INDEX MAP 
Common blue-green aigae can accumulate urantum in flowing streans. Several samples of algae of unidentified types were collected at Bokan Mountain. Th1s plant is difficult to sample, because it is seldom abundant enough to provide an adequate-size sample. It is almost impossible to collect algae without including a certain amount of sediment.

A few moss samples were included to determine to what extent they accumulate metals. While having very shallow roots, mosses are widespread throughout Alaska. Huckleberry, one of the most common bushes in the wooded areas on Bokan Mountain, also was sampled wherever it occurred at a sample station.

A stream crossing che Ross-Adams mine propercy and flowing to Kendrick Bay was sampled at several points between its mouth and the mine to see how well stream sediment fines would serve for geocherical prospecting for urantum. Stream sediment analysis is not a biogeochemical method.

Analyses of all the samples collected for this project were made by Union Carbide Exploration Corporation at thedr laboratory in Grand Junction, Colorado. A summary of the methods used follows:

\begin{tabular}{|c|c|}
\hline Uranium: & $\begin{array}{l}\text { assayed by the fluorimetric procedure using a flux of } \\
\text { sodium and lithium fluoride. Accuracy to } 1 \text { ppm } \\
\text { uranium. }\end{array}$ \\
\hline Vanad1um: & $\begin{array}{l}\text { assayed by the hydrogen-peroxide colorimetric procedure, } \\
\text { Sensitivity to } 1 \text { ppm vanadium. }\end{array}$ \\
\hline Molybd eaum: & $\begin{array}{l}\text { assayed by atomic absorption. } \\
\text { molybdenum. }\end{array}$ \\
\hline Arsenic: & $\begin{array}{l}\text { assayed by the silyer diethyldichlocarbonate colori- } \\
\text { metric procedure. Sensitivity to } 1 \text { ppm arsentc. }\end{array}$ \\
\hline Copper: & assayed by atomic absorption. \\
\hline Manganese and ztnc: & $\begin{array}{l}\text { assayed by atomic absorption. Because of the high } \\
\text { concentrations both were reported in percentages. }\end{array}$ \\
\hline
\end{tabular}

* ppra means parrs per million 
Analyses of the various plants, mulch, and stream sediment samples are listed in tables 1 chrough 12. Maps showing the sample locations and analyses for each type of plant and material are included. Extremely high uranium values were obtained from many of the samples collected near the ore body. Average background values cannot be calculated because the laboratory reported that the sample size in many cases was too small for exact determination of uranium below a certain level, generally 3 to 20 ppu, The range of uranium assays, including all samples, is from less than 1 to 2396 ppm, The hlgher values correspond well with the known near-surface distribution of uranium mineralization. The few scattered samples collected from the Atom-Marietta claims gave rather poor and inconsistent results.

Background or noxmal uranium content for most of the materials and plants sampled, based on the lower values reported, apparently is less chan $3 \mathrm{ppm}$. The small number of stream sediment samples prevents estimating a background value for this material, but the lowest was $7 \mathrm{ppm}$.

There is litcle or no correlation between uranium content and vanadium, molybdenum, arsenic, copper, manganese, and zinc content. These accessory metals are more characteristic of sedimentary-type uranium deposits rather than vein-type or those associated with grantitic rocks.

It was not possible to standardize the sampling, because of the variable surface condiflons and unequal distribution of plant types. Therefore, it is difficult to accurately compare the relaclve merits of using one or another plant for geobotantcal prospecting in the area. However, lodgepole pine is the most useful of the plants sanipled in the area,

All the plant types sampled, with the possible exception of blueberry and alder, evidently can accumulate anomalous anounts of uranium. Also, uranium in the test area Is concentrated in humus. Radiometric measurements showed that mulch or humus gene:ally contains more radioactive matter than underlying granite.

Comments on each of the types of materials sampled Eollow:

Living lodgepole pine (table 1 and fig 13) Lodgepole pine was sampled at 88 locations and produced uranium assays ranging from less than 1 to $2396 \mathrm{ppm}$. Th土s plant is one of the most abundant and widely distributed in the area, and appears to be the most useful In geobotanical prospecting for uranium there. The better root system no doubt helps account for its relatively high sensitivity to uranium in soil. The pattern of analyses reflects the near-surface mineralization very well.

Dead lodgepole pine (table 2 and fig 14) The 22 samples of twigs and burls from dead lodgepole pine had assays ranging from 7 to 1230 ppa uranium. The average uranium concentration appears to be higher in the dead material than in the Iiving plants, especially those from locations noth and up slope from the Ross-Adans mine,

Spruce (table 3 and fig 15) Spruce trees were sampled at 41 locations, and yielded values from less than 2 to 315 ppr. Spruce ls less abundant than lodgepole pine and cedar, and does not appear to accumulate uranium as well. However, relatively high values were obtalned from the vicinity of the old mine workings.

Western cedar (table 4 and fig 16) Western cedar grows abundantly in the area and was sampled at 108 locations, Uranium assays ranged from less than 1 to 2127 ppm, Background appears to be less than $3 \mathrm{ppm}$. Cedar assays generally are lower than for lodgepole pine at the same locations and do not define the mineralized areas as well as the pine assays. 
Western hemlock (table 5 and fig 1?) Western henlock is not as abundant in the area as cedar and lodgepole pine and was found at only 48 of the sample sites. The assays ranged from less than 2 to $901 \mathrm{ppm}$. The distriburion of significantly high assays corresponds well with the known minerallzation, but the number of assays is too small co compare the merits of hentock with other plants.

Juniper (table 6 and fig 18) Nineteen samples of juniper had urantum values ranglng Erom less than 2 to $159 \mathrm{ppm}$. While the higher assays from over the ore zone seem to indicace that juniper can serve as an accumulacor plant, its shallower root system probably makes it less efficient than larger crees.

Blueberry (table 7 and $f i g$ 19) Nineceen samples of blueberry bushes had uranium values ranging from less than 20 to $30 \mathrm{ppm}$. Compared with ocher p.lants, blueberry showed only low uranium values. Though the samples collected were the same size as those of other plants, they proved to be insufficient for accurate ash analyses. All but two samples were simply reported as less than 20 ppm or less than 30 ppon.

Algae (table 8 ard fig 20) Thirleen algae samples have uranium values ranging from 2 to $1833 \mathrm{ppm}$. The highest values were from small streams and pools a few hundred feet north of the open cul, suggesting that this material can accumulate large amounts of uranium even in areas with relatively low uranium in the beclock. It appears that the algae north of the mine are accumulating uranium derived trom the granite upslope rather than an ore body. However, sampling of algae in xoutine prospecting is not practical because they usually are not avaliable in adequate quantities and carbonaceous or silty nater la1 cannot be separated completely from such samples.

Miscellaneous plants (tabte 9 and $\int i g$ 2.1) 'lhis group of samples Includes the following: 5 ilder, 2 club noss, 1 luketkea pectinalit, 3 crowbercy, and 2 unidenctfied shrubs. The range in uranjum assays was from less than 3 to 923 ppm. These plants were too sparsely distributed to be useful. i'he uranium content of such low-growing, shallow-root plants seens unusuilly high, but the hlgh values we from immed lately over mineralized ground,

Mulch and soil (tabie 10 and $\mathrm{fig} 22$ ) The 41 mulch and sold samples yielded urantum assays from 1 to $441 \mathrm{ppm}$ and show that uranium is concentrated in the humus here. The material sampled was the hunic layer just below the moss cover. While it is called mulch, the material unavoidably contulned some silt and live moss roots. The ease and convenience of sampling mulch rather than plancs seens to make it preferable where conditions are simflar. to those at Bokan Mountain. Mulch sample coverage of the test area is poor, partly because of the lack of sufflcient mulch axound the mine, However, analyses show high values which indicate thit there has been a buildup of uranium at the surface by the accumulation of decomposed plant material.

Stream sedinents (table 11 and fig 23) Nine stream sediment samples were collected from a stream beginning above the Ross-Adams open cut to a point neax its entrance into Kendrick Bay, a distance of slightly more than one mile. Uranium values ranged between 7 and $554 \mathrm{ppm}$ and produce a nearly ldeal assay profile. Three samples near the upper end of the open cut had values of 7,8 , and 33 ppm. Starting at a point just below the lower tunnel the values in sequence downstrean were 554, 253, 291, 198, and 77 ppm. Surface mining and the mine duinp have probably caused a considerable increase in the uranium in the sediments above what it would be if the area had not been disturbed. Many more stream samples should be collected and analyzed for uranium to decermine thetr value for uranium prospecting in the reglon. While stream sediment sampling has generally been considered unsuitable for uxanlun prospecting because of its solubility, tt 1 much moxe convenient and rapid than geobotanical prospecting. 
Lichen On the west side of che saddle on the south side of Bokan Yountain at an elevation of about 1600 feet, the writer noted a bright orange lichen growing on granite outcrops. Tnis Iichen evidently has acted as a uranium accumulator. Repeated checking with a sclacillometer showed the lichen-coated portions of the grante to have two to four times as much radioactivity as the other nearby rock.

The lichen, identified by Dr. Leslie A. Viereck, U. S. Forest Service, as a spectes of Lecidea (possibly Lecidea Lapicida) may serve as a good indicator plant for uranium. This lichen is known to have the ability to extract tron from rock, and the concentration of uranium by it at Bokan Mountain may illustrate an ability to extract certain lons. The single area where this plant was noted was perhaps 100 feet widc. This limited observation does not permit one to say whether lichen grows preferentially upon high uraniumbearing rock or not, but only that it at least has a tolerance for uranium and can concentrate the metal under proper conditions.

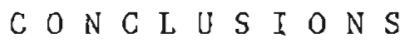

Sampling at the Ross-Adams mine shows that a variety of plants and materials nay produce highly anomalous uranium in a uranium mining district, but in varylng degrees. Of the plants sampled, the lodgepole pine proved the most useful because of its wide distribution, the relative ease of obtaining an adequate sample, and the plant's sensttlvity to uranium $i_{1}$ che soil. Mulch overlying the Bokan Mountain granite showed definite uranium concentrations. Measurements with a scintillometer frequently failed to indlcate radioactivity. Geobotanical sampling may be especially helpful in defining the outines and limits of urantum deposits once they have been detected.

While stream sediment sampling produced an almost ldeal assay pattern along a stream dralating from the uinerallzed area, the number of samples collected ard the area sampled were too limited to determine thelr value for prospecting. The effects that mining has inad on the sample results are not known. The Division plans to continue resting stream sedinent sampling and other prospecting techniques to ald in locating the most favorable geologie settings for posstble veln-type and sedimentary-type urantum deposits in Alaska. 


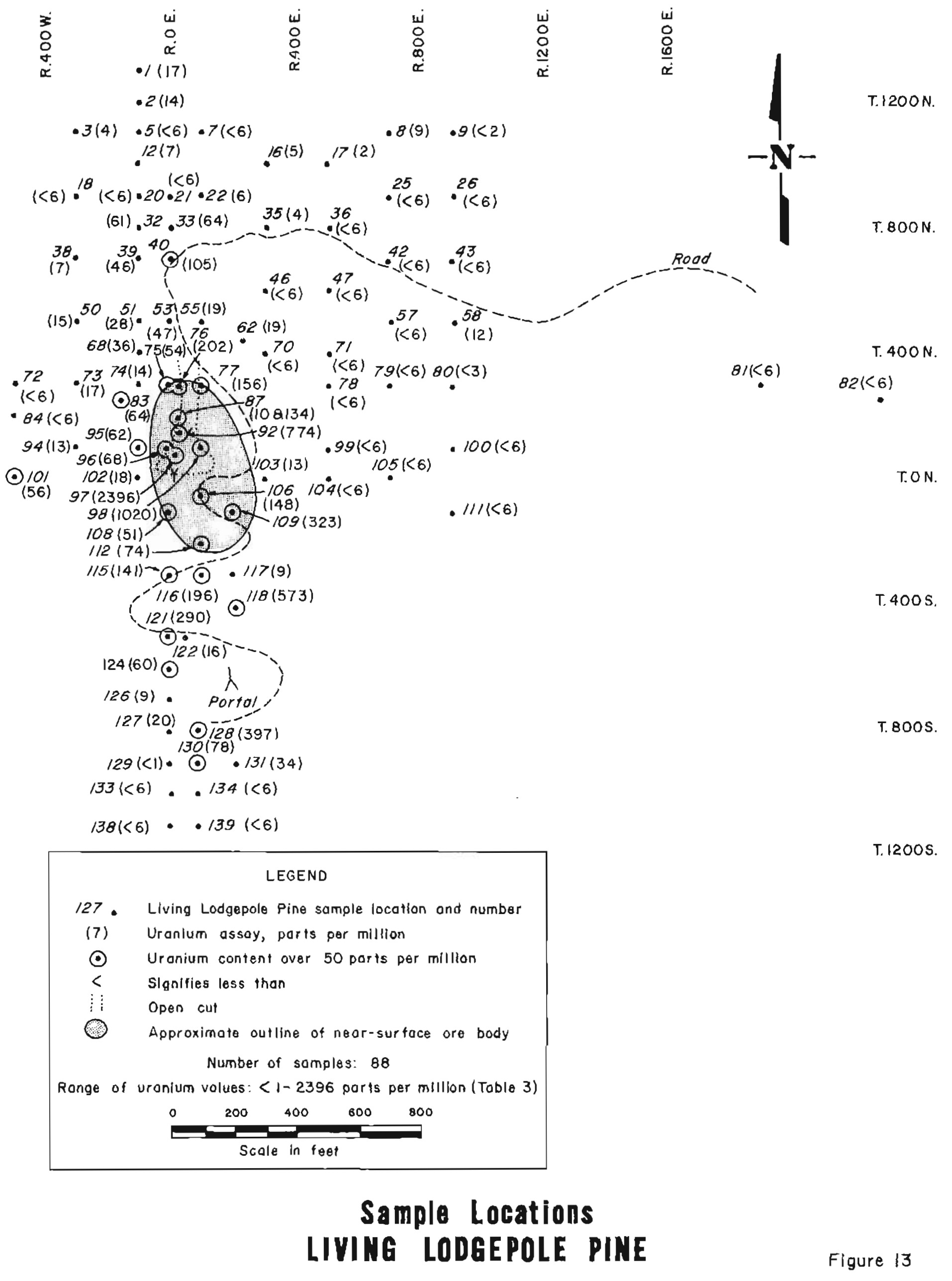




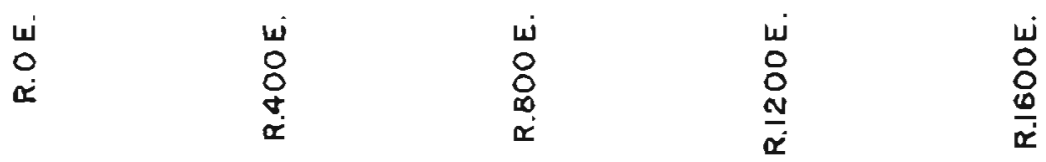

$0^{5(86)}$

- $9(<6)$

T.1200N.

T. BOON.

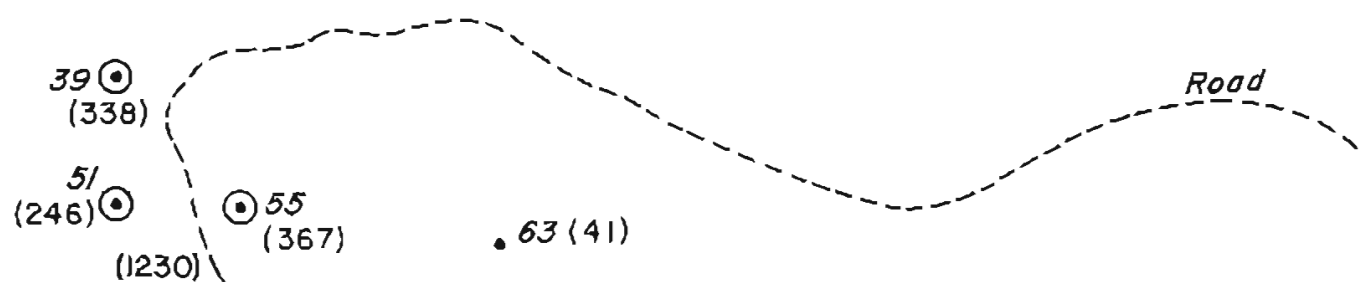

(271)

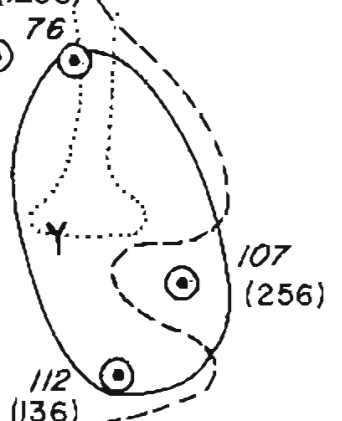

. $89(41)$

82.

$.99(7)$

T. ON.

(I36)

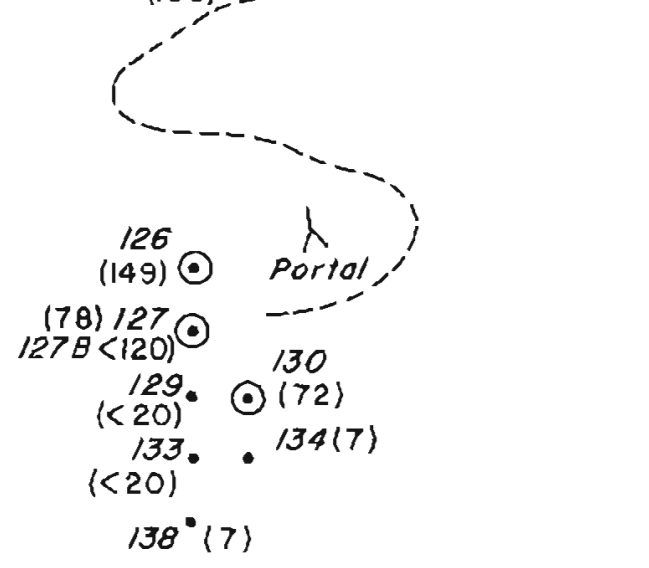

T. $400 \mathrm{~s}$,

T. $800 \mathrm{~s}$

LEGEND

T. $1200 \mathrm{~S}$

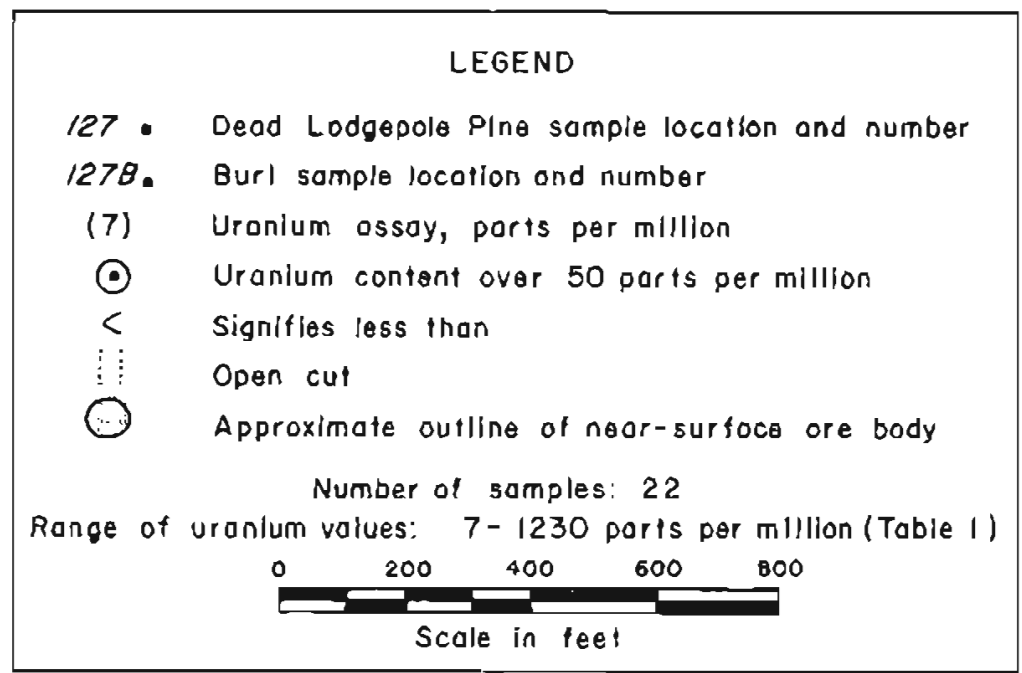

\section{Sample Locations




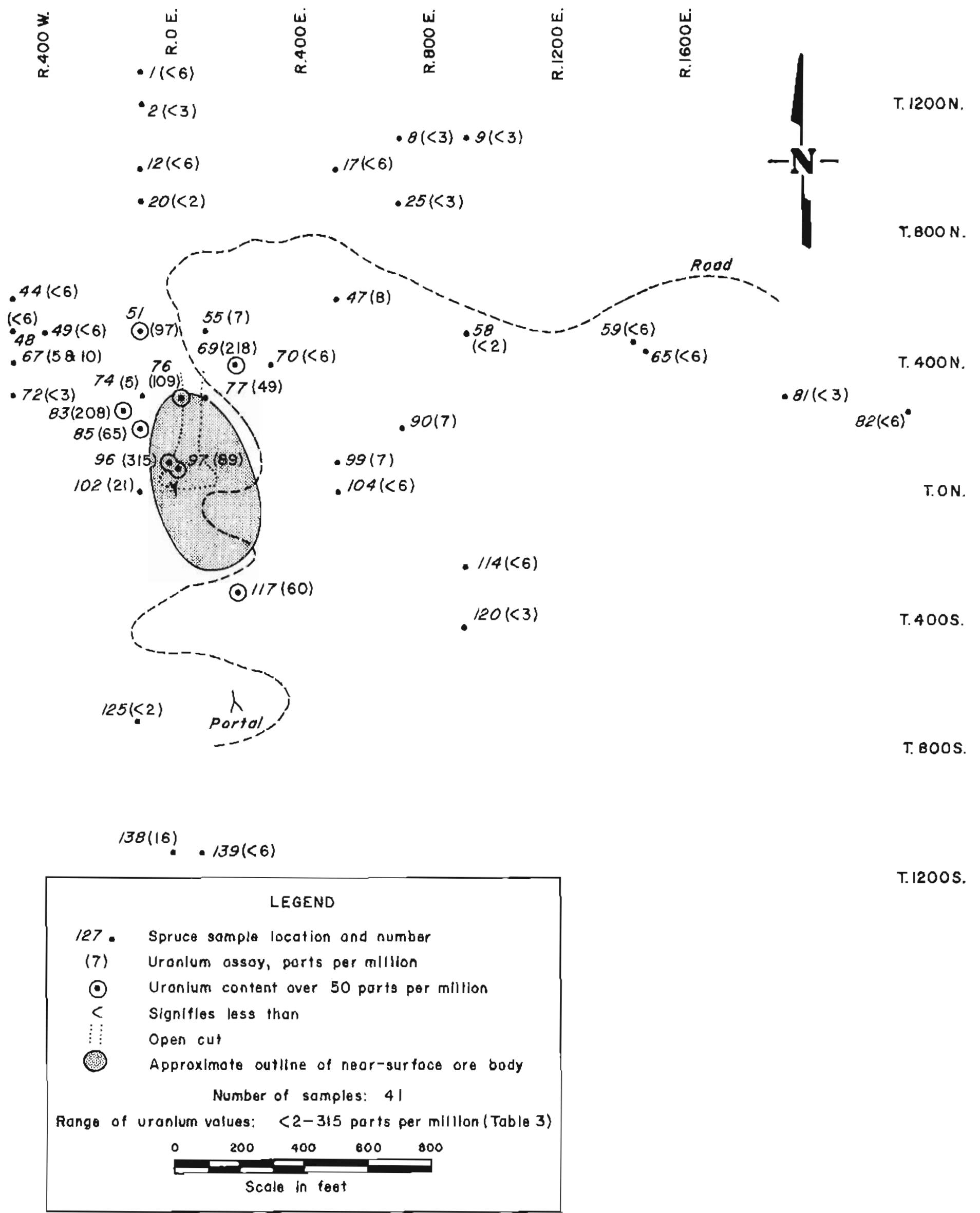




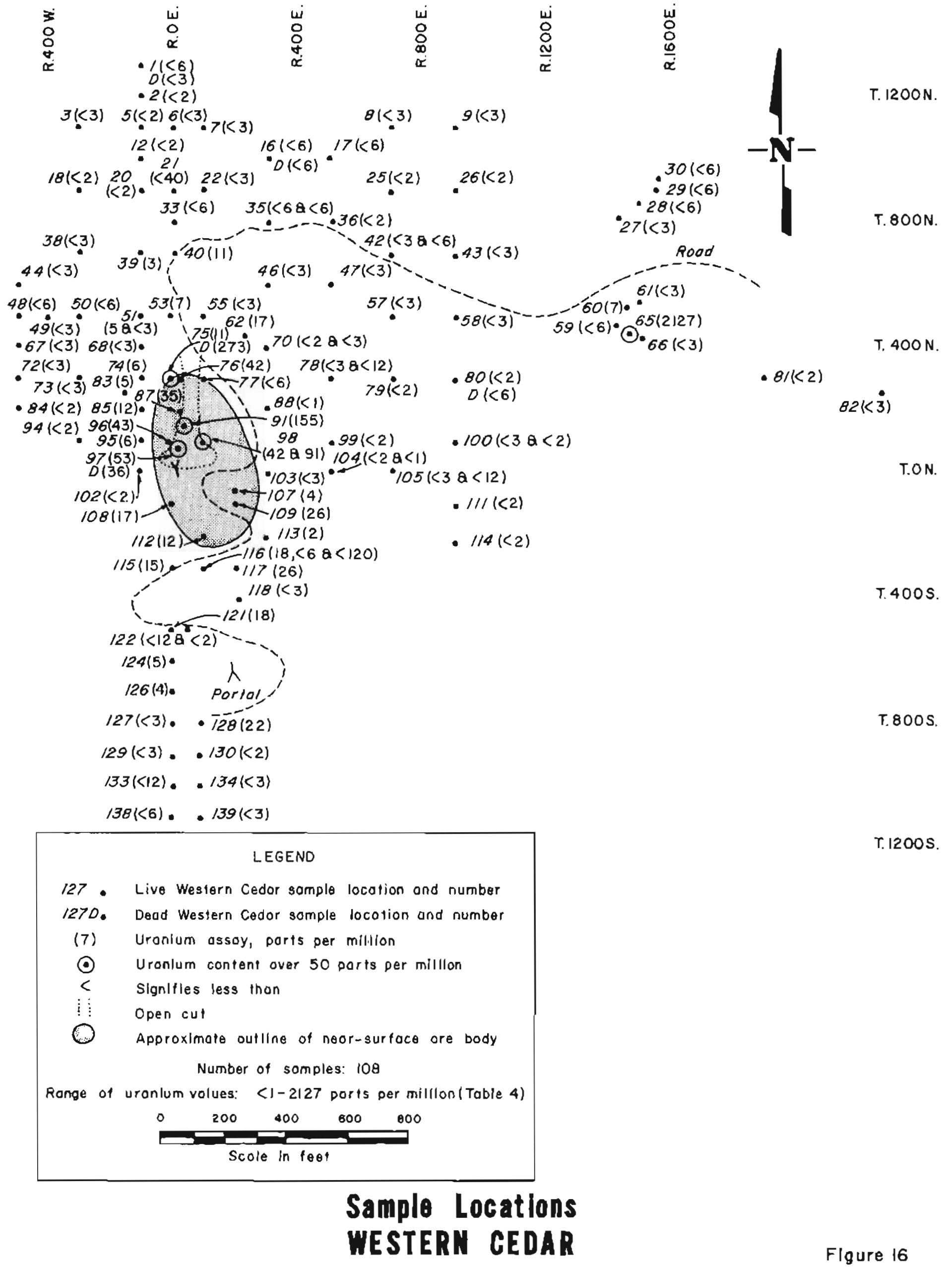




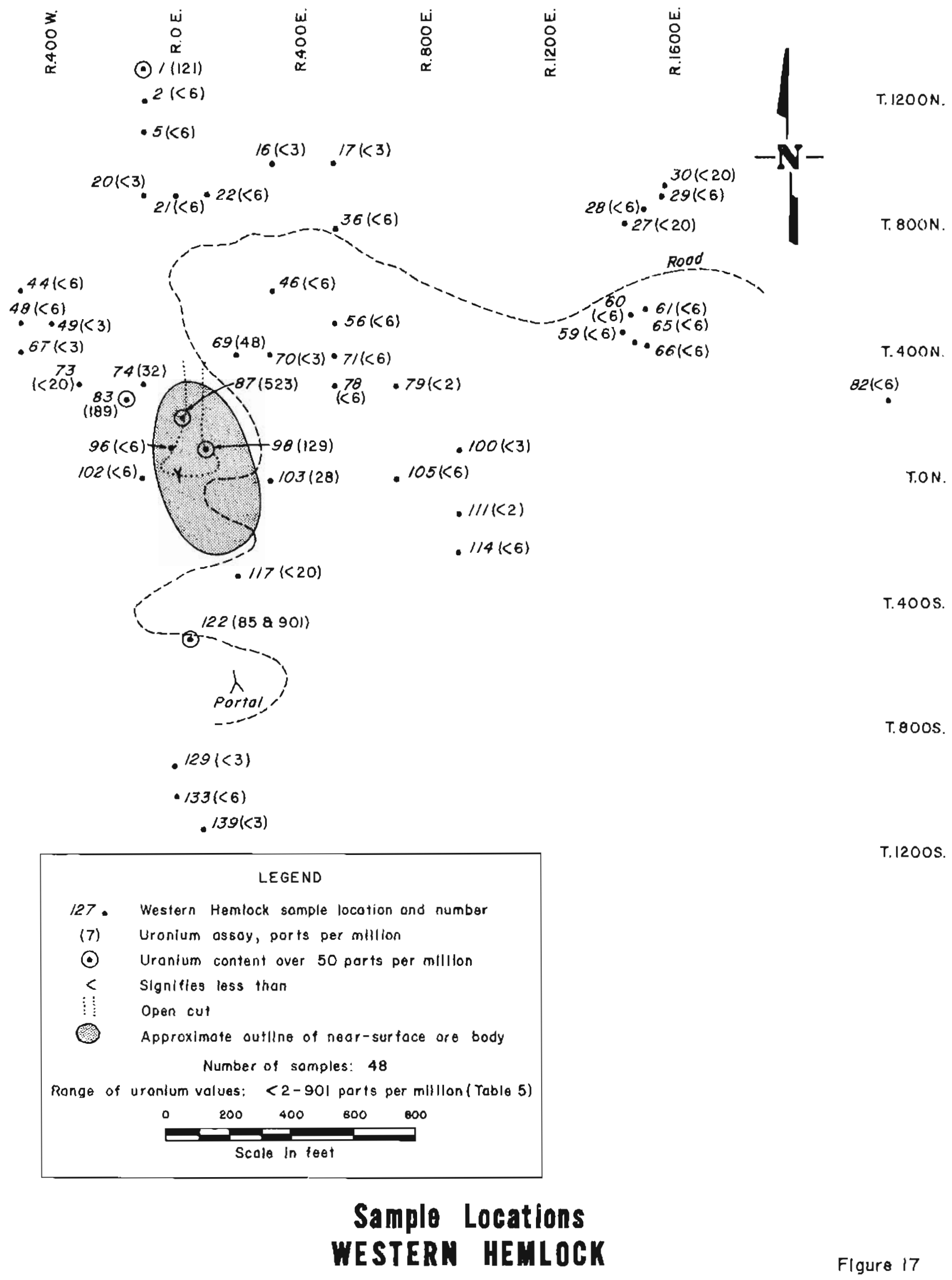




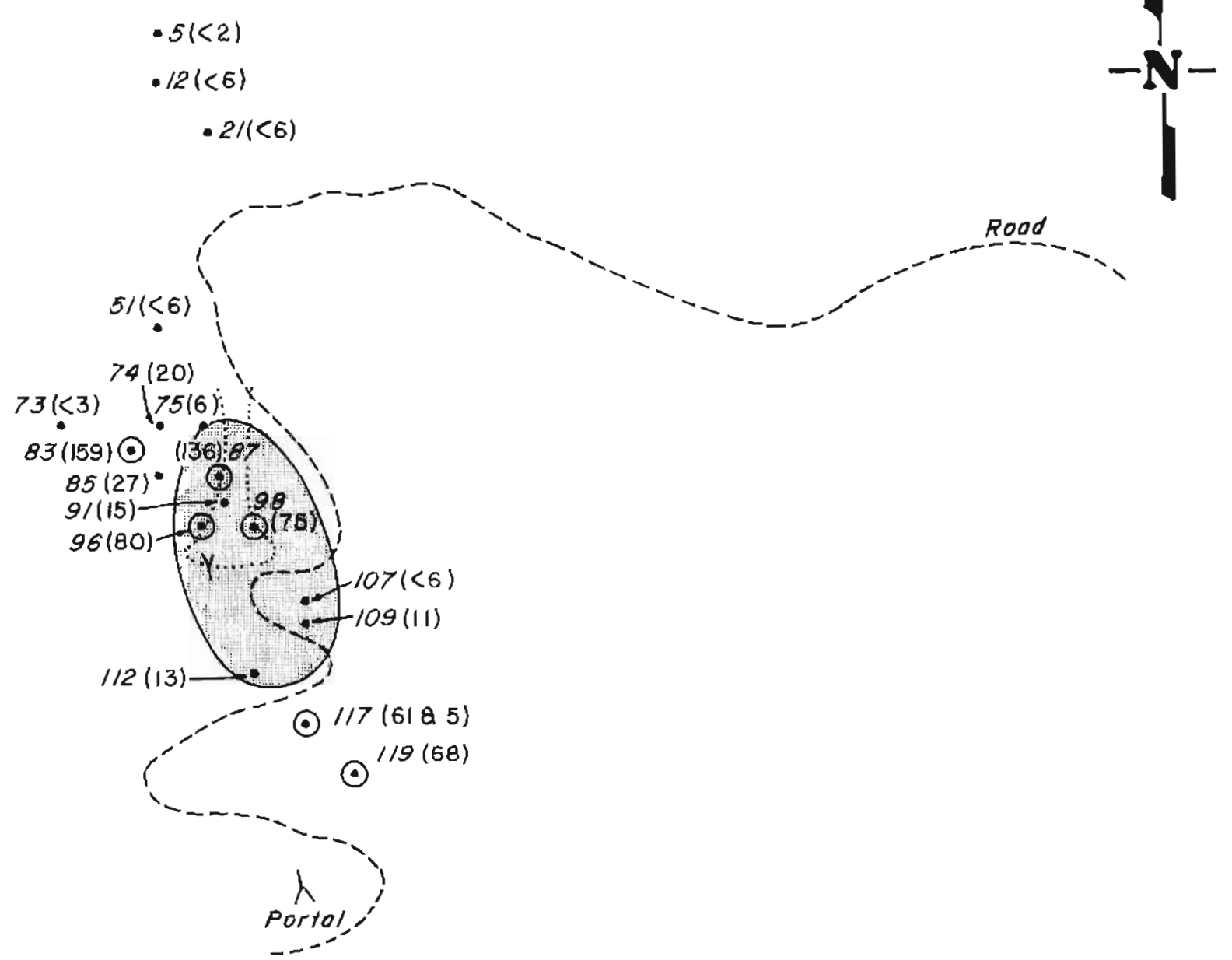

T.400N.

T.ON.

T.400S.

T. 800 S.

LEGEND

T. $1200 \mathrm{~S}$.

127. Juniper sample locotion and number

(7) Uranium assoy, parts per million

- Uranium content over 50 parts per million

$<$ Signifies less than

Open cut

Approximote outline of near-surfoce ore body Number of samples: 19

Range of uranfum values: <2- 159 parts per million (Table 6)

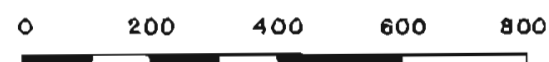

scale in foet

\section{Sample Locations}



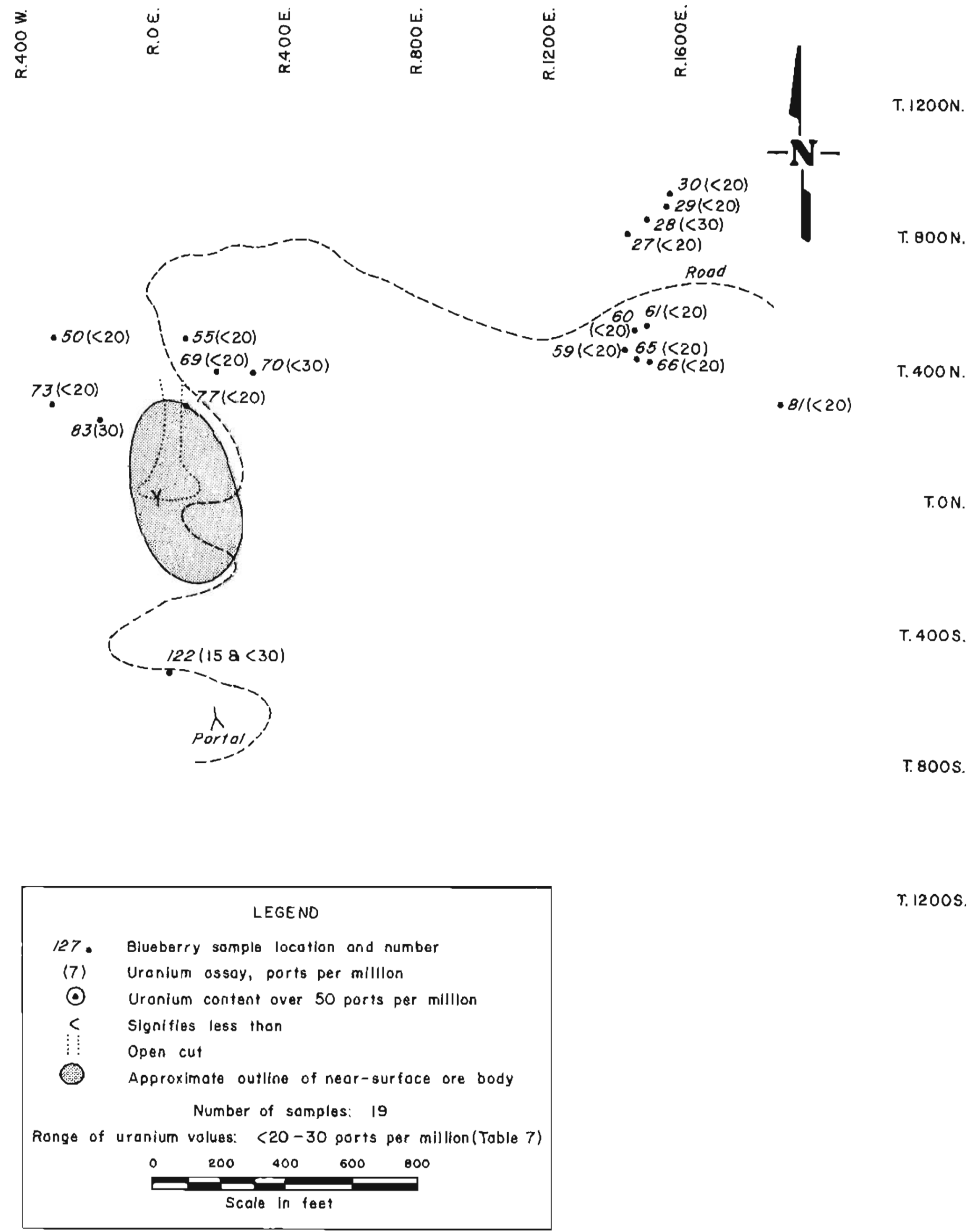

T. $1200 \mathrm{~s}$

\section{Sample Locations




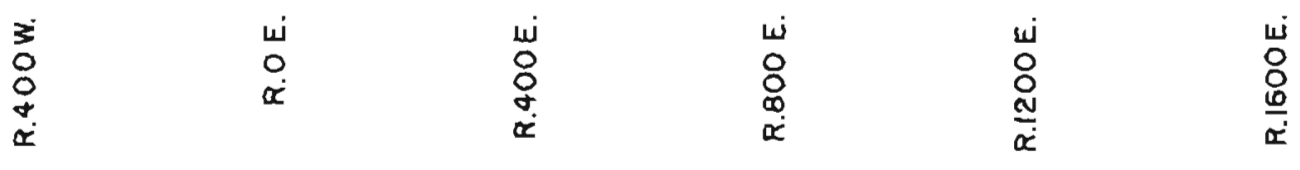

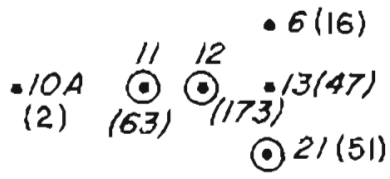

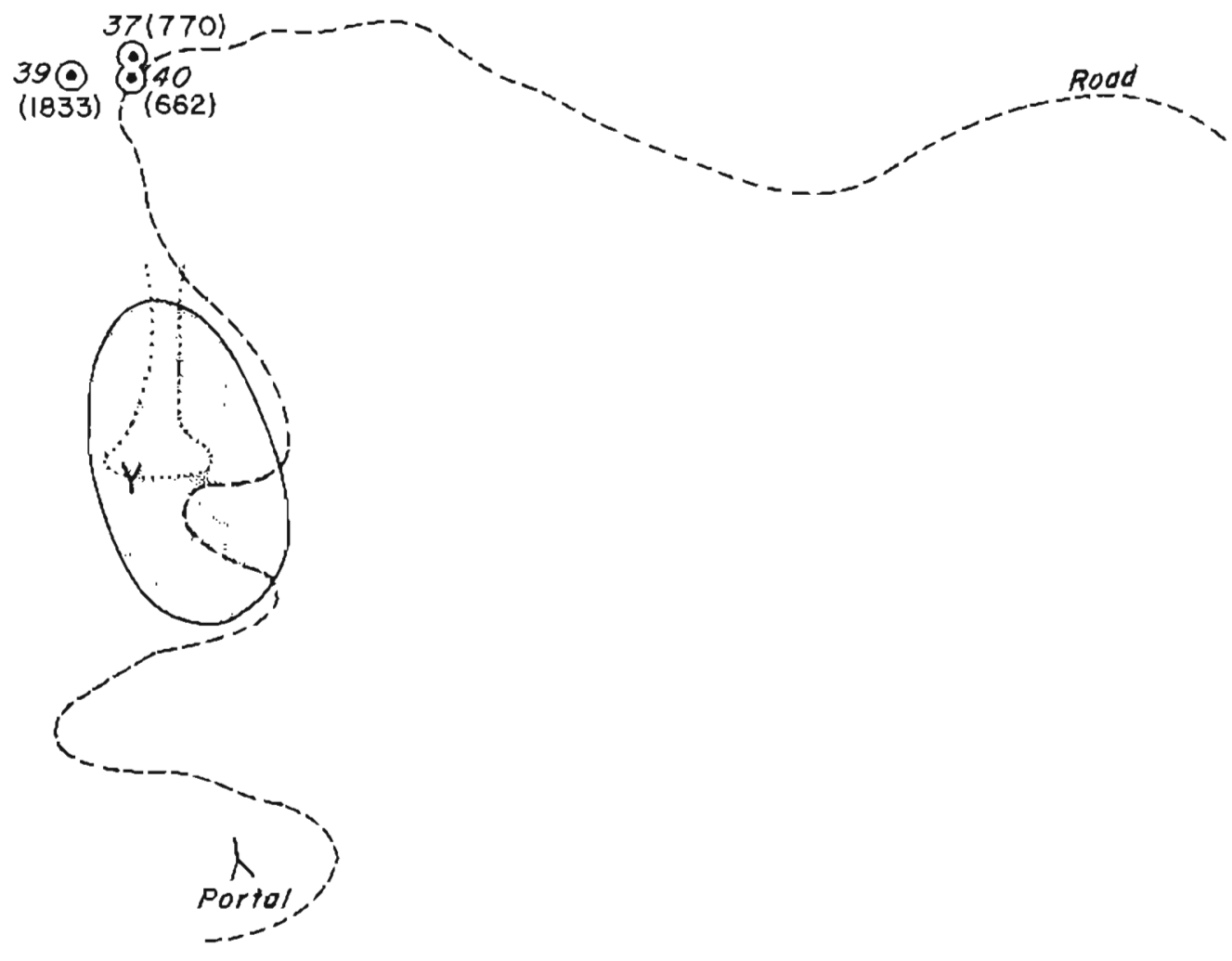

T. $800 \mathrm{~N}$.

T. $1200 \mathrm{~N}$.

T. $400 \mathrm{~N}$.

T.ON.

T. 4005 .

- $135(14)$

$.139(28)$

\section{LEGEND}

T. $1200 \mathrm{~s}$

127. Algoe somple locotion and number

(7) Uranium assoy, parts per million

- Uranlum content over 50 parts per million

$<$ Signifles less thon

O Open cut

3

Approximote outline of neor-surfoce ore body

Number of samples: 13

Ronge of uronium values: $2-1883$ parts per million (Table 8 )

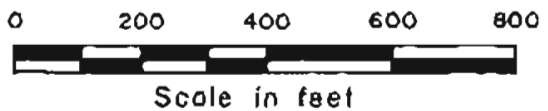

NOTE: Algoe somples from locations off map:

1. Near comp on Kendrick Boy (5)

2. West end of Kendrick Bay at shoreline (20) 

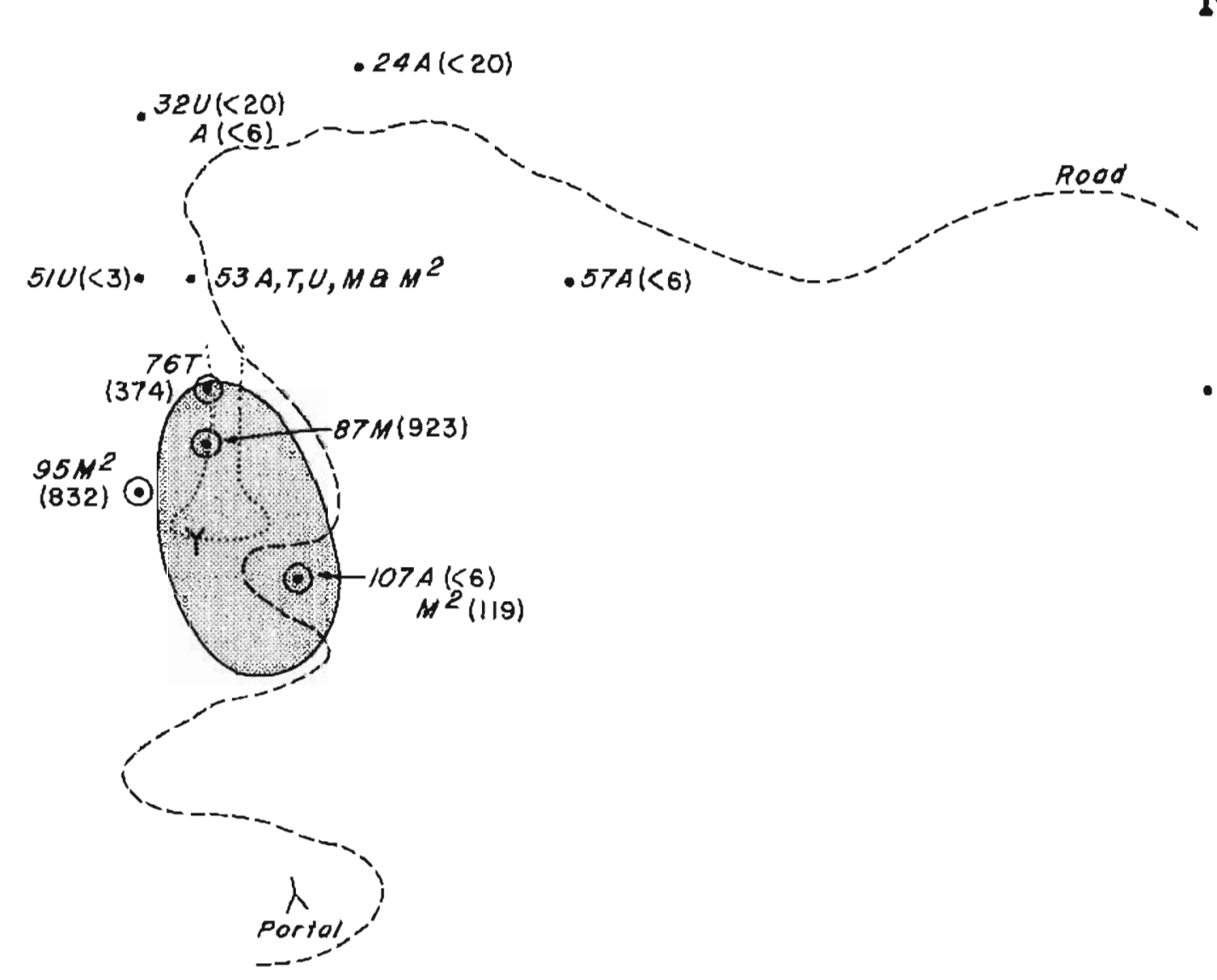

T.ON.

\section{LEGEND}

32A Aloer sample location and number

327 - Club Moss(Lycopodium clovfum L.) sample location and number

$32 \mathrm{M}$ - Luketkeo pectincto sampla location and number

32M2. Crowberry (Empeirum nigrlm L.) sample location and number

- $8 / M^{2}(<20)$

$T(<20)$

T. $400 \mathrm{~N}$.

T. 800 N.

$32 U$ - Unidentifled shrub sample locotion and number

(7) Uronium assay, ports per million

(-) Uranium confent over 50 parts por mllylon

$<$ Signifles less than

$\vdots$ Open cut

(3)

Approximote outline of near-surface ore body

Number of samplas: 13

Ronge of uranlum values: $<3-923$ ports per mililion (Toble 9 )

0 $400 \quad 600 \quad 800$

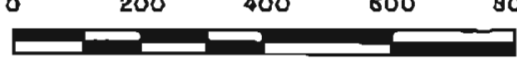

Scale In teet

T.400S

T. 8005

T.1200S.

\section{Sample Locations}




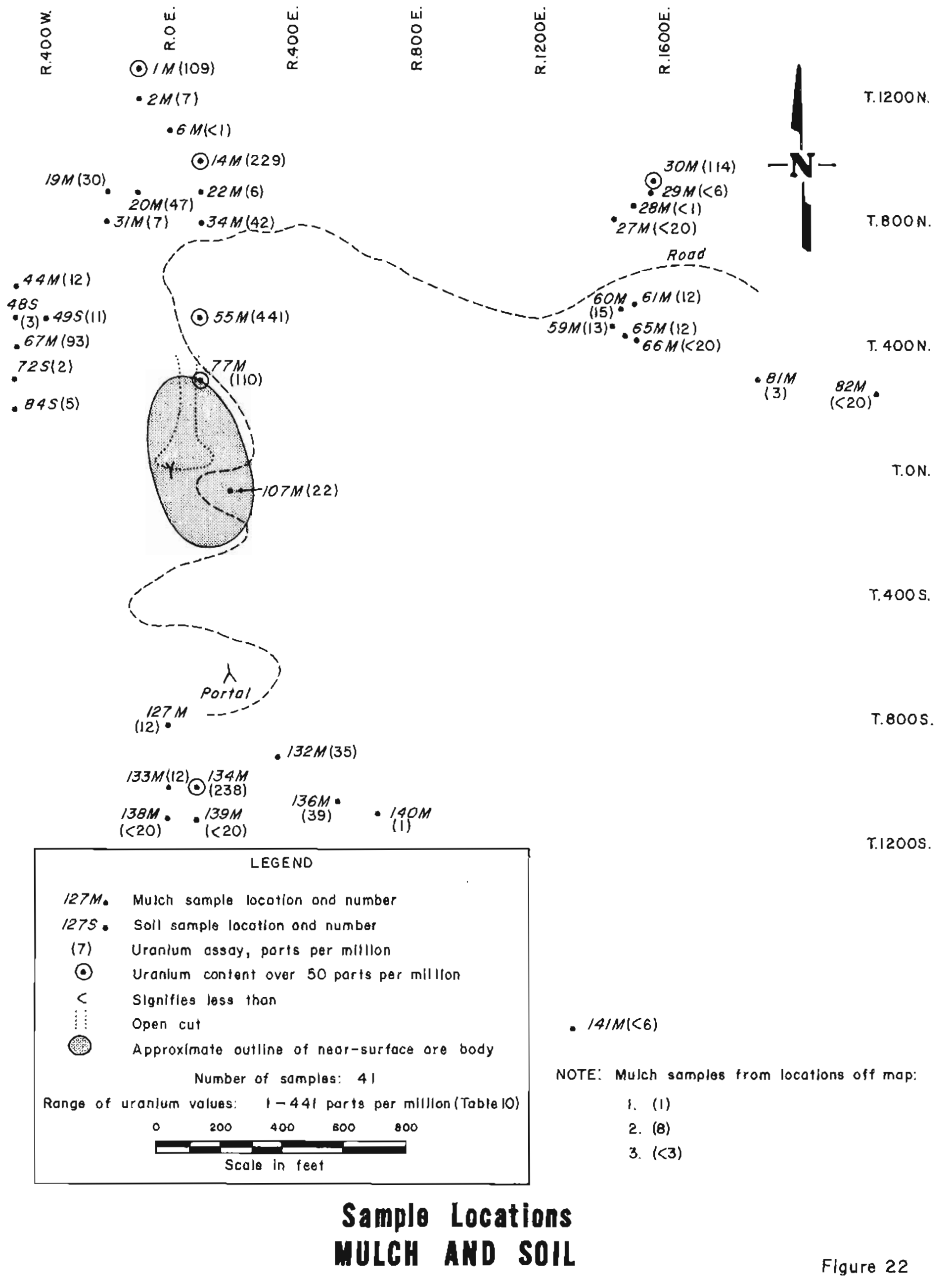




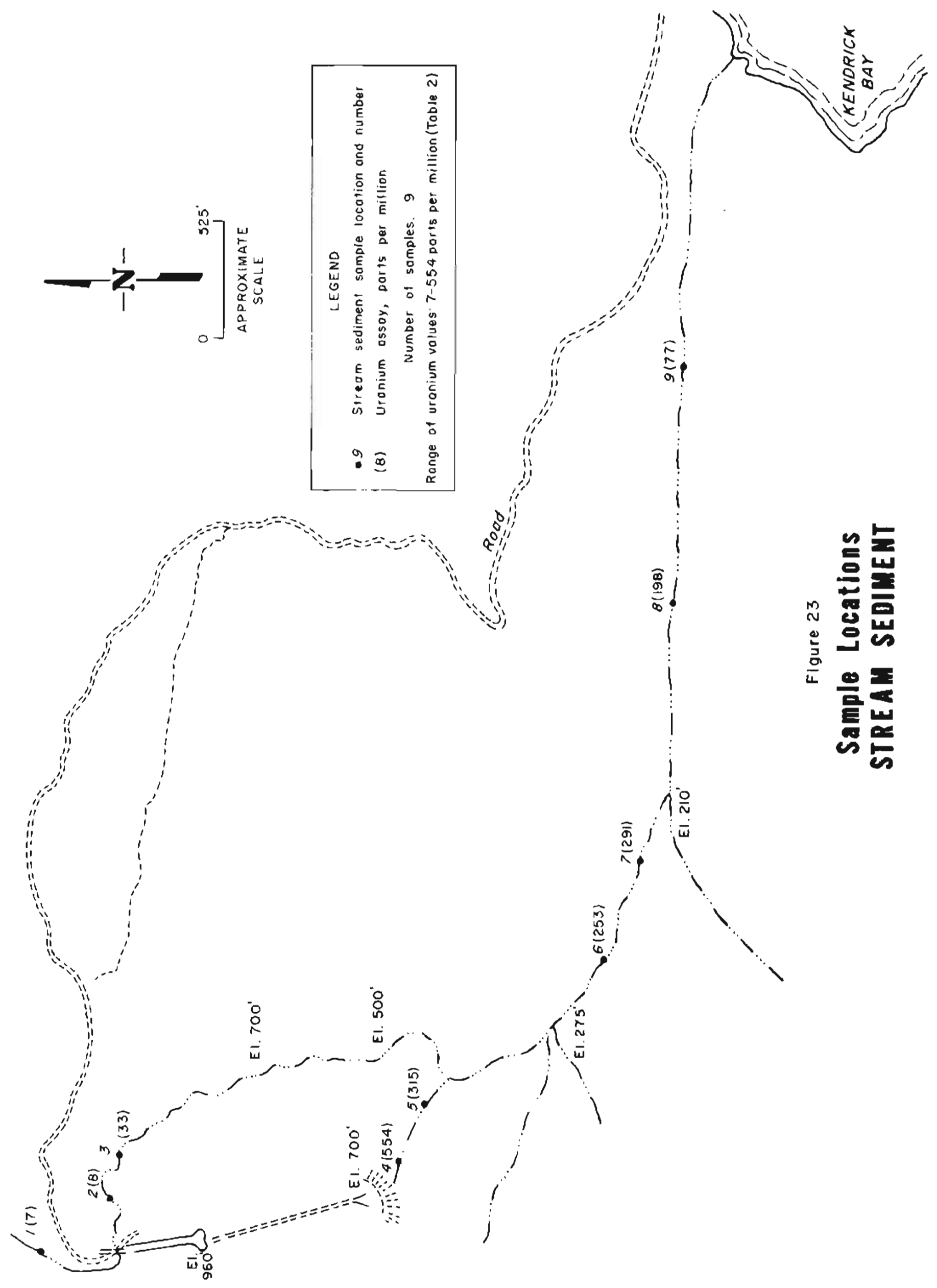


EXPLANATION OF THE TABLES

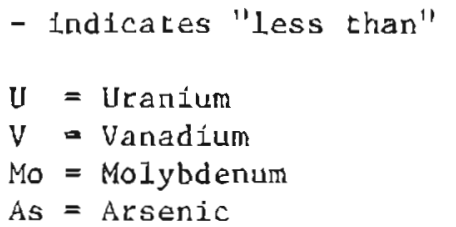
I.S. Indicates Insufficient sample for analysis
$\mathrm{Cu}=$ Copper
Mn - Manganese
$\mathrm{Zn}=\mathrm{Zinc}$

Table 1

Living Lodgepole Pine

Ash Analyses

\begin{tabular}{|c|c|c|c|c|c|c|c|c|c|}
\hline $\begin{array}{l}\text { Map } \\
\text { No, }\end{array}$ & $\begin{array}{l}\text { Field } \\
\text { No. }\end{array}$ & $\begin{array}{c}\text { Analytical } \\
\text { Code No. }\end{array}$ & $\begin{array}{c}U \\
\mathrm{PPM}\end{array}$ & $\begin{array}{c}V \\
\text { ppin } \\
\end{array}$ & $\begin{array}{l}\text { Mo } \\
\mathrm{ppm}\end{array}$ & $\begin{array}{l}\text { As } \\
\text { PPm }\end{array}$ & $\begin{array}{l}\mathrm{Cu} \\
\mathrm{ppm}\end{array}$ & $\begin{array}{r}\mathrm{Mn} \\
\% \\
\end{array}$ & $\begin{array}{r}2 n \\
\% \\
\end{array}$ \\
\hline 1 & $100 \mathrm{~W}-1300 \mathrm{~N}$ & 43323 & 17 & -150 & 20 & 49 & -10 & 5.00 & .28 \\
\hline 2 & $100 \mathrm{~W}-1200 \mathrm{~N}$ & 43322 & 14 & -150 & 10 & 3 & 20 & 4.10 & .22 \\
\hline 3 & U300W-1100N & 43330 & 4 & -75 & -10 & 5 & 35 & 3.40 & .27 \\
\hline 5 & $100 \mathrm{~W}-1100 \mathrm{~N}$ & 43378 & -6 & -150 & 60 & 4 & 20 & 3.10 & .44 \\
\hline 7 & $100 \mathrm{E}-1100 \mathrm{~N}$ & 43394 & -6 & -150 & 10 & 1 & 10 & 5.30 & .22 \\
\hline 8 & $700 E-1100 \mathrm{~N}$ & 43337 & 9 & -150 & -10 & 32 & 10 & 1.20 & .16 \\
\hline 9 & $900 \mathrm{E}-1100 \mathrm{~N}$ & 43334 & -2 & -50 & -10 & 1 & 3.0 & 0.73 & .09 \\
\hline 12 & $100 \mathrm{~W}-1000 \mathrm{~N}$ & 43321 & 7 & -150 & 40 & 7 & -10 & 2.80 & 260 \\
\hline 16 & $300 \mathrm{E}-1000 \mathrm{~N}$ & 43325 & 5 & -150 & 10 & 34 & -10 & 4.10 & .19 \\
\hline 17 & U500E-1000N & 43324 & 2 & -75 & 15 & 3 & 20 & 1,50 & .19 \\
\hline 18 & $300 \mathrm{~W}-900 \mathrm{~N}$ & 43348 & -6 & -150 & -10 & 10 & 2 & 1.30 & .25 \\
\hline 20 & $100 \mathrm{~W}-900 \mathrm{~N}$ & 43376 & -6 & -150 & -10 & 4 & -10 & 4.20 & .14 \\
\hline 21 & U0OW-900N & 43361 & -6 & -150 & 40 & 20 & 15 & 2,10 & .22 \\
\hline 22 & U100E-900N & 43342 & 6 & -150 & 20 & -10 & 11 & 2.70 & .30 \\
\hline 25 & $700 \mathrm{E}-900 \mathrm{~N}$ & 43360 & -6 & -150 & -10 & -10 & 19 & 2.20 & .20 \\
\hline 26 & $900 \mathrm{E}-900 \mathrm{~N}$ & 43347 & -6 & -150 & -10 & -10 & 3 & 1.30 & .35 \\
\hline 32 & $100 \mathrm{~W}-800 \mathrm{~N}$ & 43370 & 61 & -150 & -10 & 4 & -10 & 3.20 & .23 \\
\hline 33 & $0 \mathrm{~W}-800 \mathrm{~N}$ & 43379 & 64 & -150 & 50 & 1 & 30 & 4.70 & .54 \\
\hline 35 & U300E-800N & 43326 & 4 & -75 & 10 & 6 & 30 & ]. .55 & .15 \\
\hline 36 & U500E-800N & 43372 & -6 & -150 & -10 & 4 & -10 & 2,60 & .19 \\
\hline 38 & $4300 \mathrm{~N}-700 \mathrm{~N}$ & 43332 & 7 & -1.50 & -10 & 30 & 10 & 1.60 & .24 \\
\hline 39 & $100 \mathrm{~W}-700 \mathrm{~N}$ & 43381 & 46 & -150 & 60 & 9 & 20 & 5.00 & .35 \\
\hline 40 & $00 \mathrm{~W}-700 \mathrm{~N}$ & 43335 & 105 & -75 & -10 & 13 & 30 & 1.75 & .21 \\
\hline 42 & $700 \mathrm{E}-700 \mathrm{~N}$ & 43345 & -6 & -150 & 10 & -10 & 5 & 1.00 & .35 \\
\hline 43 & $900 \mathrm{E}-700 \mathrm{~N}$ & 43404 & -6 & -150 & -10 & 3 & 10 & 1.40 & .23 \\
\hline 46 & U300E-600N & 43385 & -6 & -150 & -10 & 2 & 20 & 2.60 & .25 \\
\hline 47 & $500 \mathrm{E}-600 \mathrm{~N}$ & 43386 & -6 & -150 & -10 & 8 & 30 & 4.20 & .22 \\
\hline 50 & $\mathrm{U} 300 \mathrm{~W}-500 \mathrm{~N}$ & 43338 & 15 & -150 & 60 & 23 & 10 & 2.70 & .23 \\
\hline 51 & $100 \mathrm{~W}-500 \mathrm{~N}$ & 43390 & 28 & -75 & -10 & 3 & 85 & 5.01 & .21 \\
\hline 53 & $0 W-500 N$ & 43685 & 47 & I.S. & -20 & 3 & 100 & 2.8 & .099 \\
\hline
\end{tabular}


Table 1 (Contd)

\begin{tabular}{|c|c|c|c|c|c|c|c|c|c|}
\hline $\begin{array}{l}\text { Map } \\
\text { No. }\end{array}$ & $\begin{array}{l}\text { Field } \\
\text { No.. }\end{array}$ & $\begin{array}{c}\text { Analytical } \\
\text { Code No, }\end{array}$ & $\begin{array}{c}U \\
\text { ppm }\end{array}$ & $\begin{array}{c}V \\
\text { ppm }\end{array}$ & $\begin{array}{l}\text { Mo } \\
\text { ppm }\end{array}$ & $\begin{array}{l}\text { As } \\
\text { ppm }\end{array}$ & $\begin{array}{l}\mathrm{Cu} \\
\mathrm{PPm}\end{array}$ & $\begin{array}{r}\mathrm{Mn} \\
\% \\
\end{array}$ & $\begin{array}{r}\mathrm{Zn} \\
\% \\
\end{array}$ \\
\hline 53 & OW- $500 \mathrm{~N}$ & 43333 & 47 & -75 & 60 & 11 & 55 & 0.95 & .25 \\
\hline 55 & $100 \mathrm{E}-500 \mathrm{~N}$ & 43393 & 19 & -150 & -10 & 3 & -10 & 6.40 & .27 \\
\hline 57 & $700 \mathrm{E}-500 \mathrm{~N}$ & 43373 & -6 & -150 & 10 & 4 & -10 & 2.30 & .11 \\
\hline 58 & $900 E-500 N$ & 43340 & 12 & -150 & 10 & 26 & 60 & 1,60 & .38 \\
\hline 62 & $200 E-450 N$ & 43403 & 19 & -150 & 10 & 3 & 60 & 1.60 & .180 \\
\hline 68 & $100 \mathrm{~W}-400 \mathrm{~N}$ & 43357 & 36 & -150 & -10 & -10 & 17 & 1.70 & .19 \\
\hline 70 & U30OE-400N & 43344 & -6 & -150 & -10 & -10 & 4 & 4.00 & .16 \\
\hline 71 & $5001:-400 \mathrm{~N}$ & 43377 & -6 & -150 & 40 & 1 & -10 & 2.60 & .26 \\
\hline 72 & $500 \mathrm{~W}-300 \mathrm{~N}$ & 43354 & -6 & -150 & -10 & 10 & 14 & 2.80 & .21 \\
\hline 73 & U300W-300N & 43329 & 17 & -150 & -10 & 4 & -10 & 3,10 & .20 \\
\hline 74 & $100 \mathrm{~W}-300 \mathrm{~N}$ & 43405 & 14 & -150 & -10 & 2 & 30 & 3.70 & .15 \\
\hline 75 & $0 W-300 N$ & 43355 & 54 & -150 & -10 & -10 & 1 & 2.00 & .20 \\
\hline 76 & $25 E-300 N$ & 43387 & 202 & -150 & 60 & 7 & 10 & 3.50 & .20 \\
\hline 77 & $100 \mathrm{E}-300 \mathrm{~N}$ & 43362 & 156 & -150 & -10 & 20 & 21 & 2.80 & .22 \\
\hline 78 & $500 \mathrm{E}-300 \mathrm{~N}$ & 43365 & -6 & -150 & -10 & 19 & -10 & 1.50 & .18 \\
\hline 79 & U700E-300N & 43375 & -6 & -150 & 10 & 3 & -10 & 4.30 & .17 \\
\hline 80 & $900 \mathrm{E}-300 \mathrm{~N}$ & 43358 & -3 & -75 & 35 & 25 & 6 & 2.80 & .12 \\
\hline 81 & $A^{\prime} T^{\prime}-9$ & 43396 & -6 & -150 & -10 & 3 & 10 & 0.40 & .15 \\
\hline 82 & $A^{\prime} T-10$ & 43395 & -6 & -.150 & 20 & 2 & 30 & 2,70 & .24 \\
\hline 83 & $150 \mathrm{~W}-250 \mathrm{~N}$ & 43380 & 64 & -150 & 50 & 6 & 50 & 2.10 & .30 \\
\hline 84 & $500 \mathrm{~W}-200 \mathrm{~N}$ & 43397 & -6 & -150 & -10 & 5 & -10 & 2,00 & .16 \\
\hline 87 & $35 E-200 N$ & 4338.3 & 10 & -150 & 40 & 14 & 30 & 3.20 & .24 \\
\hline 87 & OW-200N & 43369 & .234 & -150 & 10 & 1 & 20 & 1.50 & .19 \\
\hline 92 & $50 \mathrm{E}-150 \mathrm{~N}$ & 43389 & 774 & -150 & -10 & 17 & 40 & 3.20 & .26 \\
\hline 94 & U300W-100N & 43339 & 13 & -1.50 & 60 & 34 & 10 & 4.00 & .18 \\
\hline 95 & $100 \mathrm{~W}-100 \mathrm{~N}$ & 43320 & 62 & -75 & 20 & 6 & 40 & 3,57 & .215 \\
\hline 96 & $0 E-100 N$ & 43363 & 68 & -150 & -10 & 15 & 20 & 2.30 & .170 \\
\hline 97 & OW-100N & 43428 & 2396 & -100 & 15 & 7 & 15 & 1,90 & .33 \\
\hline 98 & U100E-100N & 43341 & 1020 & -150 & -10 & 30 & 41 & 2.10 & .19 \\
\hline 99 & $500 \mathrm{E}-100 \mathrm{~N}$ & 43366 & -6 & -150 & 50 & 15 & -10 & 2.20 & .20 \\
\hline 100 & $900 \mathrm{E}-100 \mathrm{~N}$ & 43374 & -6 & -150 & -10 & 2 & -10 & 4,20 & .16 \\
\hline 101 & $500 \mathrm{~W}-\mathrm{ON}$ & 43356 & 56 & -150 & 30 & -10 & 15 & 1,80 & .15 \\
\hline 102 & $100 W-O N$ & 43319 & 18 & -75 & 10 & 6 & 15 & 3.20 & .185 \\
\hline 103 & U300E-ON & 43331 & 13 & -150 & 20 & 11 & -10 & 2.40 & .28 \\
\hline 104 & $500 \mathrm{E} \sim \mathrm{ON}$ & 43359 & -6 & -150 & -10 & -10 & 15 & 1.20 & .11 \\
\hline 105 & $700 \mathrm{E}-\mathrm{ON}$ & 43343 & -6 & -150 & -10 & -10 & 9 & 3.60 & .26 \\
\hline 106 & $100 E-50 S$ & 43353 & 148 & -150 & 10 & -10 & 2 & 3.90 & .23 \\
\hline 108 & $0 E-100 S$ & 43346 & 51 & -150 & -10 & -10 & 4 & 2,20 & .23 \\
\hline 109 & $200 \mathrm{E}-100 \mathrm{~S}$ & 43400 & 323 & -75 & 5 & 2 & 30 & 2.95 & .20 \\
\hline 111 & $900 \mathrm{E}-100 \mathrm{~S}$ & 43350 & -6 & -150 & -10 & -10 & 11 & 3,60 & .17 \\
\hline
\end{tabular}


Table 1 (Contd)

\begin{tabular}{|c|c|c|c|c|c|c|c|c|c|}
\hline $\begin{array}{l}\text { Map } \\
\text { No. }\end{array}$ & $\begin{array}{c}\text { Field } \\
\text { No. }\end{array}$ & $\begin{array}{c}\text { Analytical } \\
\text { Code No. }\end{array}$ & $\begin{array}{c}U \\
\mathrm{ppm}\end{array}$ & $\begin{array}{c}V \\
p p m\end{array}$ & $\begin{array}{l}\text { Mo } \\
\text { PpDl }\end{array}$ & $\begin{array}{l}\text { As } \\
\text { Ppm }\end{array}$ & $\begin{array}{l}\mathrm{Cu} \\
\mathrm{ppm}\end{array}$ & $\begin{array}{r}\text { Mn } \\
\% \\
\end{array}$ & $\begin{array}{r}\mathrm{Zn} \\
\%\end{array}$ \\
\hline 112 & $100 E-200 S$ & 43401 & 74 & -75 & -10 & 1 & 45 & 1.40 & .115 \\
\hline 115 & OE-300S & 43368 & 141 & -150 & 40 & 21 & 10 & 2.70 & .25 \\
\hline 116 & ID100E-300S & 43336 & 196 & -50 & -10 & 11 & 33 & 1.63 & .13 \\
\hline 117 & $200 E-3005$ & 43398 & 9 & -50 & -10 & 1 & 20 & 1.43 & .10 \\
\hline 118 & $200 E-400 S$ & 43382 & 573 & -150 & 70 & 15 & 50 & 2.30 & .29 \\
\hline $12 I$ & $\mathrm{OE}-500 \mathrm{~S}$ & 43399 & 290 & -75 & -10 & 2 & 30 & 4,00 & .26 \\
\hline 122 & $50 \mathrm{E}-500 \mathrm{~s}$ & 43327 & 16 & -75 & -10 & 4 & -10 & 2.65 & .15 \\
\hline 122 & ID 50-500S & 43328 & I $\mathrm{N}$ & $U F E I$ & I E N T & & $M P L$ & & \\
\hline 124 & OE-600S & 43391 & 60 & -150 & -10 & 5 & 40 & 2,60 & .23 \\
\hline 126 & $O E-700 S$ & 43367 & 9 & -150 & 20 & 6 & 10 & 1,80 & .21 \\
\hline 127 & $O E-800 S$ & 43392 & 20 & -150 & -10 & 4 & 50 & 1,80 &, 24 \\
\hline 128 & $100 E-800 S$ & 43388 & 397 & -150 & 10 & 11 & 40 & 4.10 & .35 \\
\hline 129 & $0 \mathrm{E}-900 \mathrm{~S}$ & 43384 & -1 & -150 & 50 & 6 & 30 & 5,10 & .28 \\
\hline 130 & $100 E-900 S$ & 43364 & 78 & -150 & -10 & 14 & 10 & 2.60 & .18 \\
\hline 131 & $300 \mathrm{E}-900 \mathrm{~S}$ & 43406 & 34 & -150 & -10 & 5 & 10 & 1.50 & .28 \\
\hline 133 & $0 E-1000 S$ & 43352 & -6 & -150 & -10 & -10 & 2 & 5.40 & .21 \\
\hline 134 & $100 \mathrm{E}-1000 \mathrm{~S}$ & 43349 & -6 & -150 & -10 & -10 & 4 & 4.30 & .30 \\
\hline 138 & OE-1100S & 43371 & -6 & -150 & -10 & 3 & -10 & 3.10 & .19 \\
\hline 139 & $100 \mathrm{E}-1100 \mathrm{~S}$ & 43351 & -6 & -150 & -10 & -10 & 6 & 5.40 & .18 \\
\hline
\end{tabular}


Table 2

Dead Lodgepole Pine and Buris

Ash Analyses

\begin{tabular}{|c|c|c|c|c|c|c|c|c|c|}
\hline $\begin{array}{l}\text { Map } \\
\text { No. }\end{array}$ & $\begin{array}{l}\text { Field } \\
\text { No. }\end{array}$ & $\begin{array}{c}\text { Analytical } \\
\text { Code No. }\end{array}$ & $\begin{array}{c}\mathrm{U} \\
\mathrm{pm}\end{array}$ & $\begin{array}{c}V \\
\text { epm } \\
\end{array}$ & $\begin{array}{l}\text { Mo } \\
\text { Ppn }\end{array}$ & $\begin{array}{l}\text { As } \\
\mathrm{ppm}\end{array}$ & $\begin{array}{l}\mathrm{Cu} \\
\mathrm{ppm}\end{array}$ & $\begin{array}{r}M n \\
\% \\
\end{array}$ & $\begin{array}{r}2 n \\
\%\end{array}$ \\
\hline 5 & $100 \mathrm{~W}-1100 \mathrm{~N}$ & 43421 & 86 & $I, S$. & -20 & 2 & -20 & -.20 & .04 \\
\hline 9 & $900 E-1100 \mathrm{~N}$ & 43427 & -6 & I.S. & -20 & 2 & -20 & .20 & .07 \\
\hline 16 & $300 \mathrm{E}-1600 \mathrm{~N}$ & 43420 & -.00 & I.S. & -50 & 5 & -50 & -.50 & .16 \\
\hline 39 & $100 \mathrm{~W}-700 \mathrm{~N}$ & 43412 & 338 & I.S. & -50 & 7 & -50 & -.30 & .10 \\
\hline 51 & $100 \mathrm{~W}-500 \mathrm{~N}$ & 43416 & 246 & -150 & -10 & 6 & -10 & .10 & .04 \\
\hline 55 & $100 \mathrm{E}-500 \mathrm{~N}$ & 43413 & 367 & I.S. & -20 & 9 & -20 & .40 & .07 \\
\hline 63 & $500 E-45 C N$ & 43426 & 41 & I.S. & -10 & 2 & 80 & .60 & .10 \\
\hline 74 & $100 W-300 N$ & 43408 & 271 & I, S, & -50 & 4 & 30 & .40 & .17 \\
\hline 76 & $25 \mathrm{E}-300 \mathrm{~N}$ & 43418 & 1230 & -150 & -10 & 2. & -10 & -.10 & .02 \\
\hline 82 & AT10 & 43423 & -40 & I,S. & -30 & 3 & -30 & .30 & .11 \\
\hline 89 & $500 \mathrm{~W}-300 \mathrm{~N}$ & 4341.1 & $4 I$ & $I, S$ & -20 & 7 & -20 & .80 & .09 \\
\hline 99 & $500 \mathrm{~L}-100 \mathrm{~N}$ & 43410 & 7 & -150 & -10 & 2 & -10 & .10 & .04 \\
\hline 107 & $200 \mathrm{E}-50 \mathrm{~S}$ & 43414 & 256 & -150 & -10 & 8 & 80 & .40 & .06 \\
\hline 112 & $100 \mathrm{~B}-200 \mathrm{~S}$ & 43422 & 136 & -50 & -10 & 1 & 10 & -.10 & .01 \\
\hline 126 & $0 E-700 S$ & 43419 & $\operatorname{L49}$ & -150 & -10 & 1 & -10 & .10 & .03 \\
\hline 127 & $0 E-800 \mathrm{~S}$ & 43407 & $-\perp 20$ & $I, S$, & -100 & 14 & -100 & -1.0 & .21 \\
\hline 127 & OE-800S & 43415 & 78 & $\Gamma, S$, & -20 & 13 & -20 & -.20 & .06 \\
\hline 129 & OE-900S & 43686 & -20 & -150 & -15 & 11 & 60 & 2.33 & 077 \\
\hline 130 & $100 E-9005$ & 43424 & 72 & I, S, & 25 & 2 & 10 & .30 & .06 \\
\hline 133 & OE-1000S & 43409 & -20 & -275 & -20 & 2 & -20 & .23 & .06 \\
\hline 134 & $100 \mathrm{E}-1000 \mathrm{~S}$ & 43425 & 7 & -100 & -10 & 1 & -10 & -.10 & .03 \\
\hline 138 & OE-1100S & 43417 & 7 & I.S. & -20 & 11 & -20 & .266 & .07 \\
\hline
\end{tabular}


Table 3

Spruce

Ash Analyses

\begin{tabular}{|c|c|c|c|c|c|c|c|c|c|}
\hline $\begin{array}{l}\text { Map } \\
\text { No. }\end{array}$ & $\begin{array}{l}\text { Field } \\
\text { No, }\end{array}$ & $\begin{array}{c}\text { Analytical } \\
\text { Code No. }\end{array}$ & $\begin{array}{c}\text { U } \\
\text { ppn }\end{array}$ & $\begin{array}{c}V \\
\text { ppq }\end{array}$ & $\begin{array}{l}\text { Mo } \\
\text { epm }\end{array}$ & $\begin{array}{l}\text { As } \\
\text { ppm }\end{array}$ & $\begin{array}{l}\mathrm{Cu} \\
\text { epm }\end{array}$ & $\begin{array}{r}\mathrm{Mn} \\
\% \\
\end{array}$ & $\begin{array}{r}\mathrm{Zn} \\
\% \\
\end{array}$ \\
\hline 1 & $100 \mathrm{~W}-1300 \mathrm{~N}$ & 43537 & -6 & -150 & -10 & 14 & -10 & 9.7 & .02 \\
\hline 2 & $100 \mathrm{~W}-1200 \mathrm{~N}$ & 43536 & -3 & -75 & -5 & 7 & -5 & 7.8 & .01 \\
\hline 3 & $700 E-I 100 N$ & 43545 & -3 & -75 & 20 & 9 & 10 & 3.55 & .40 \\
\hline 9 & $900 \mathrm{E}-1100 \mathrm{~N}$ & 43569 & -3 & -75 & 5 & 1 & -5 & 1.20 & .01 \\
\hline 12 & $100 \mathrm{~W}-1000 \mathrm{~N}$ & 43544 & -6 & -150 & 10 & 24 & -10 & 7.00 & .04 \\
\hline 17 & U500E-1000N & 43538 & -6 & -150 & -10 & 10 & -10 & 5.8 & .03 \\
\hline 20 & $100 \mathrm{~W}-900 \mathrm{~N}$ & 43553 & -2 & -50 & 7 & -1 & -3 & 1,77 & .01 \\
\hline 25 & $700 \mathrm{E}-900 \mathrm{~N}$ & 43566 & -3 & -75 & 20 & 3 & -5 & 3.00 & .02 \\
\hline 44 & $500 \mathrm{~W}-600 \mathrm{~N}$ & 43562 & -6 & -150 & -10 & -1 & -10 & 4.30 & .04 \\
\hline 47 & $500 \mathrm{E}-600 \mathrm{~N}$ & 43539 & 8 & -75 & 30 & 8 & -5 & 7.65 & .03 \\
\hline 48 & $500 \mathrm{~W}-500 \mathrm{~N}$ & 43559 & -6 & -150 & -10 & -1 & -10 & 4.30 & .03 \\
\hline 49 & $400 \mathrm{~W}-500 \mathrm{~N}$ & 43546 & -6 & -150 & -10 & 2 & -10 & 3.60 & .04 \\
\hline 51 & $100 \mathrm{~W}-500 \mathrm{~N}$ & 43568 & 97 & I.S. & -12 & 9 & -12 & 4.22 & .04 \\
\hline 55 & $100 \mathrm{E}-500 \mathrm{~N}$ & 43564 & 7 & -50 & 17 & 4 & -3 & 1,50 & .008 \\
\hline 58 & $900 \mathrm{E}-500 \mathrm{~N}$ & 43552 & -2 & -50 & 10 & $I$ & 10 & 2.63 & .30 \\
\hline 59 & AT-4 & 43570 & -6 & -150 & -10 & 6 & -10 & 4.80 & .03 \\
\hline 65 & $\mathrm{AT}-1$ & 43560 & -6 & -150 & -10 & 7 & -10 & 2.40 & .03 \\
\hline 67 & $500 \mathrm{~W}-400 \mathrm{~N}$ & 43561 & 5 & -75 & 15 & 8 & -5 & 6.10 & .03 \\
\hline 67 & $500 \mathrm{~W}-400 \mathrm{~N}$ & 43573 & 10 & I.S, & -20 & 16 & -20 & 1.35 & .11 \\
\hline 69 & $200 \mathrm{E}-400 \mathrm{~N}$ & 43557 & 218 & I.S. & -12 & 6 & -12 & 4,78 & .04 \\
\hline 70 & U300E-400N & 43549 & -6 & -150 & -10 & 7 & -10 & $4 ; 90$ & .04 \\
\hline 72 & $500 \mathrm{~W}-300 \mathrm{~N}$ & 43548 & -3 & -75 & -5 & 12 & 10 & 4.90 & .35 \\
\hline 74 & $100 \mathrm{~W}-300 \mathrm{~N}$ & 43551 & 5 & -75 & 25 & 5 & 5 & 6,85 & .02 \\
\hline 76 & $25 E-300 N$ & 43563 & 109 & I, S, & -15 & 42 & -15 & 2.25 & .10 \\
\hline 77 & $100 \mathrm{E}-300 \mathrm{~N}$ & 43535 & 49 & -1.50 & -10 & 13 & -10 & 4,9 & .03 \\
\hline 81 & $A T-9$ & 43541 & -3 & -75 & 40 & 7 & 15 & 1.65 & .02 \\
\hline 82 & AT -10 & 43571 & -6 & -150 & 10 & 13 & -10 & 6,00 & .04 \\
\hline 83 & $150 \mathrm{~W}-250 \mathrm{~N}$ & 43543 & 208 & -150 & -10 & 12 & -10 & 4.10 & .04 \\
\hline 85 & $100 \mathrm{~W}-200 \mathrm{~N}$ & 43567 & 65 & -150 & -10 & 5 & -10 & 5,30 & .05 \\
\hline 90 & $700 \mathrm{E}-200 \mathrm{~N}$ & 43534 & 7 & -150 & -10 & 17 & -10 & 2.5 & .03 \\
\hline 96 & $0 W-100 \mathrm{~N}$ & 43572 & 315 & -150 & -10 & 2 & -10 & 7.30 & .60 \\
\hline 97 & $0 W-100 \mathrm{~N}$ & 43558 & 89 & -50 & 16 & 10 & 3 & 1.57 & .30 \\
\hline 99 & US00E-100N & 43542 & 7 & -75 & 15 & 7 & 10 & 4.65 & .06 \\
\hline .02 & $100 \mathrm{~W}-\mathrm{ON}$ & 43533 & 21 & -150 & -10 & 14 & -10 & 7,9 & .04 \\
\hline .04 & $500 \mathrm{E}-\mathrm{ON}$ & 43547 & -6 & -150 & 10 & 18 & -10 & 4.50 & .05 \\
\hline 14 & $900 \mathrm{E}-200 \mathrm{~S}$ & 43554 & -6 & -150 & -10 & 60 & -10 & 10.30 & .02 \\
\hline 17 & $200 \mathrm{E}-300 \mathrm{~S}$ & 43550 & 60 & I.S. & -15 & 8 & -15 & 8.25 & .07 \\
\hline 20 & $900 \mathrm{E}-400 \mathrm{~s}$ & 43565 & -3 & -150 & -10 & -1 & -10 & 7,40 & .02 \\
\hline 25 & $100 \mathrm{w}-700 \mathrm{~s}$ & 43556 & -2 & -50 & -3 & -1 & -3 & 3.23 & .27 \\
\hline 38 & $O E-1100 S$ & 43555 & 16 & -150 & 10 & 7 & -10 & 4,40 & .04 \\
\hline 39 & $100 \mathrm{E}-1100 \mathrm{~S}$ & 43540 & -6 & -150 & -10 & 12 & -10 & 7.50 & .04 \\
\hline
\end{tabular}


Table 4

Western Cedar

Ash Analyses

\begin{tabular}{|c|c|c|c|c|c|c|c|c|c|}
\hline $\begin{array}{l}\text { Map } \\
\text { No. }\end{array}$ & $\begin{array}{c}\text { Field } \\
\text { No, }\end{array}$ & $\begin{array}{c}\text { Analycical } \\
\text { Code No. }\end{array}$ & $\begin{array}{c}\mathrm{U} \\
\mathrm{ppg}\end{array}$ & $\begin{array}{c}V \\
\mathrm{ppm}\end{array}$ & $\begin{array}{l}\text { Mo } \\
\text { PPM }\end{array}$ & $\begin{array}{l}\text { As } \\
\text { ppm }\end{array}$ & $\begin{array}{l}\mathrm{Cu} \\
\mathrm{ppm}\end{array}$ & $\begin{array}{r}\mathrm{Mn} \\
\% \\
\end{array}$ & $\begin{array}{r}\mathrm{Zn} \\
\% \\
\end{array}$ \\
\hline 1 & $100 \mathrm{~W}-1300 \mathrm{~N}$ & 43479 & -6 & -150 & -10 & 4 & -10 & 1.4 & .03 \\
\hline 1 & $100 \mathrm{~W}-1300 \mathrm{~N}$ & 43530 & -3 & -75 & -5 & 5 & -5 & -.1 & .01 \\
\hline 2 & $100 \mathrm{~W}-1200 \mathrm{~N}$ & 43463 & -2 & -50 & -3 & 2 & -3 & -.1 & .01 \\
\hline 3 & $300 \mathrm{~W}-1100 \mathrm{~N}$ & 43467 & -3 & -75 & 5 & 7 & -5 & -11 & .01 \\
\hline 5 & $100 \mathrm{~W}-1100 \mathrm{~N}$ & 43480 & -2 & -50 & 3 & $\mathbf{l}$ & -3 & -.1 & .008 \\
\hline 6 & UOW $1100 \mathrm{~N}$ & 43474 & -3 & -75 & -5 & 1 & -5 & -.1 & .01 \\
\hline 7 & $100 \mathrm{E}-1100 \mathrm{~N}$ & 43518 & -3 & -75 & 5 & 2 & -5 & -.1 & .02 \\
\hline 8 & $700 \mathrm{E}-1100 \mathrm{~N}$ & 43477 & -3 & -75 & 5 & -1 & -5 & -.1 & .01 \\
\hline 9 & $900 \mathrm{E} \sim 1100 \mathrm{~N}$ & 43486 & -3 & -75 & 5 & 5 & -5 & -.1 & .01 \\
\hline 12 & $100 \mathrm{~W}-1000 \mathrm{~N}$ & 43461 & -2 & -37 & -3 & 2 & 5 & -.1 & .008 \\
\hline 16 & U300E-1000N & 43529 & -6 & -150 & -10 & 13 & -10 & -.1 & .02 \\
\hline 16 & U300E-1000N & 43437 & -6 & -150 & -10 & 5 & -10 & .223 & .0400 \\
\hline 17 & U $500 \mathrm{E}-1000 \mathrm{~N}$ & 43491 & -6 & -150 & -10 & 10 & -10 & -.1 & .02 \\
\hline 18 & U300W-900N & 43441 & -2 & -50 & 20 & -1 & -3 & -.1 & .01 \\
\hline 20 & $100 \mathrm{~W}-900 \mathrm{~N}$ & 43465 & -2 & -37 & -3 & 1 & -3 & -.1 & .01 \\
\hline 21 & UOOW-90ON & 43501 & -40 & I.S, & -50 & 9 & -50 & -.4 & .03 \\
\hline 22 & $100 \mathrm{E}-900 \mathrm{~N}$ & 43502 & -3 & -75 & -5 & 9 & -5 & -.1 & .01 \\
\hline 25 & $700 \mathrm{E}-900 \mathrm{~N}$ & 43513 & -2 & -50 & -3 & 2 & -3 & -.1 & .01 \\
\hline 26 & $900 \mathrm{E}-900 \mathrm{~N}$ & 43466 & -2 & -50 & -3 & 1 & -3 & -.1 & .009 \\
\hline 27 & AT- 8 & 43498 & -3 & -75 & 5 & 10 & -5 & 0.3 & .01 \\
\hline 28 & $\mathrm{AT}-7$ & 43520 & -6 & -150 & -10 & 3 & -10 & 0.5 & .04 \\
\hline 29 & $A T-6$ & 43499 & -6 & -1.50 & 10 & 17 & -10 & 0.2 & .02 \\
\hline 30 & $A I-6$ & 43526 & -6 & -150 & -10 & 13 & -10 & -.1 & .03 \\
\hline 33 & OW-800N & 43500 & -6 & -150 & -10 & 32 & -10 & -.1 & .02 \\
\hline 35 & $\mathrm{l} 3300 \mathrm{E}-800 \mathrm{~N}$ & 43528 & -6 & -150 & -10 & 14 & -10 & -.1 & .02 \\
\hline 35 & $300 \mathrm{E}-800 \mathrm{~N}$ & 43483 & -3 & -75 & -5 & 6 & -5 & -.1 & .02 \\
\hline 36 & U500E-800N & 43489 & -2 & -50 & 10 & 3 & -3 & -.1 & .009 \\
\hline 38 & $300 \mathrm{~W}-700 \mathrm{~N}$ & 43485 & -3 & -75 & 20 & 8 & -5 & -.1 & .01 \\
\hline 39 & $100 \mathrm{~W}-700 \mathrm{~N}$ & 43492 & 3 & -75 & -5 & 4 & -5 & -.1 & .01 \\
\hline 40 & OW 700N & 43682 & 11 & -75 & 75 & 3 & -5 & -.1 & .02 \\
\hline 42 & $700 \mathrm{E}-700 \mathrm{~N}$ & 43472 & -3 & -75 & 5 & 5 & -3 & 0,2 & .02 \\
\hline 42 & $700 \mathrm{E}-700 \mathrm{~N}$ & 43673 & -6 & -150 & 80 & 7 & -10 & 0.50 & .04 \\
\hline 43 & $900 \mathrm{E}-700 \mathrm{~N}$ & 43454 & -3 & -75 & 5 & 5 & -5 &,- 1 & 0,12 \\
\hline 44 & $500 \mathrm{~W}-600 \mathrm{~N}$ & 43456 & -3 & -75 & 10 & 8 & 5 & 0,3 & .02 \\
\hline 46 & U300E-600N & 43523 & -3 & -75 & 20 & 3 & -5 & -.1 & .02 \\
\hline 47 & U500E-600N & 43490 & -3 & -75 & 5 & 5 & -5 & -.1 & .01 \\
\hline 48 & $500 W-500 N$ & 43475 & -6 & -150 & -5 & 3 & -5 & -.1 & .03 \\
\hline 49 & $400 W-500 N$ & 43444 & -3 & -75 & 20 & 1 & 20 & .45 & .02 \\
\hline 50 & U300W-500N & 43484 & -6 & I.S. & -10 & 1 & -10 & 0,6 & .03 \\
\hline 51 & $100 \mathrm{~W}-500 \mathrm{~N}$ & 43430 & 5 & -75 & 5 & 1 & -5 & -.1 & .02 \\
\hline
\end{tabular}


Table 4 (Contd)

\begin{tabular}{|c|c|c|c|c|c|c|c|c|c|}
\hline $\begin{array}{l}\text { Map } \\
\text { No. }\end{array}$ & $\begin{array}{c}\text { Field } \\
\text { No. }\end{array}$ & $\begin{array}{c}\text { Analytical } \\
\text { Code No. }\end{array}$ & $\begin{array}{c}U \\
\text { p }\end{array}$ & $\begin{array}{c}\mathrm{V} \\
\mathrm{ppr}\end{array}$ & $\begin{array}{l}\text { Mo } \\
\text { ppm }\end{array}$ & $\begin{array}{l}\text { As } \\
\mathrm{ppm}\end{array}$ & $\begin{array}{l}\mathrm{Cu} \\
\mathrm{pPm}\end{array}$ & $\begin{array}{r}\mathrm{Mn} \\
\% \\
\end{array}$ & $\begin{array}{r}\mathrm{Zn} \\
\% \\
\end{array}$ \\
\hline 51 & $100 \mathrm{~W}-500 \mathrm{~N}$ & 43508 & -3 & -75 & 5 & 1 & -5 & -.1 & .02 \\
\hline 53 & $0 W-500 \mathrm{~N}$ & 43450 & 7 & -75 & 20 & $I$ & 10 & -.1 & .02 \\
\hline 55 & $100 \mathrm{E}-500 \mathrm{~N}$ & 43674 & -3 & -75 & 25 & 5 & 5 & -.1 & .02 \\
\hline 57 & $700 \mathrm{E}-500 \mathrm{~N}$ & 43482 & -3 & -75 & 5 & 7 & -5 & -.1 & .02 \\
\hline 57 & $700 \mathrm{E}-500 \mathrm{~N}$ & 43476 & -3 & -75 & -10 & 2 & -10 &.$- I$ & .01 \\
\hline 58 & $900 E-500 \mathrm{~N}$ & 43469 & -3 & -75 & -5 & 5 & -5 & -.1 & .01 \\
\hline 59 & $\mathrm{~A}^{\prime} \mathrm{P}-4$ & 43515 & -6 & -150 & -10 & 5 & -10 & 0.2 & .03 \\
\hline 60 & $A T^{2}-5$ & 43521 & 7 & -150 & -10 & 16 & -10 & 0.4 & .02 \\
\hline 6.1 & $\mathrm{~A} T-2$ & 43435 & -3 & -75 & -5 & 3 & -5 & -.1 & .02 \\
\hline 62 & $200 \mathrm{E}-450 \mathrm{~N}$ & 43519 & 17 & -150 & 10 & 3 & -10 & 0.9 & .03 \\
\hline 65 & AT-1 & 43683 & 2127 & I.S. & -15 & 18 & 13 & .005 & .06 \\
\hline 66 & AT-3 & 43448 & -3 & -75 & 15 & 2 & -5 &, 80 & .01 \\
\hline 67 & $500 \mathrm{~W}-400 \mathrm{~N}$ & 43429 & -3 & -75 & -5 & 2 & -5 & -.1 & .02 \\
\hline 68 & $100 \mathrm{~W}-400 \mathrm{~N}$ & 43507 & -3 & -75 & 5 & 2 & -5 & -.1 & .01 \\
\hline 70 & U300E-400N & 43436 & -2 & -50 & 4 & 1 & -3 & -.1 & .01 \\
\hline 70 & $300 \mathrm{E}-400 \mathrm{~N}$ & 43497 & -3 & -75 & -5 & 10 & -5 & -.1 & .01 \\
\hline 72 & $500 \mathrm{~W}-300 \mathrm{~N}$ & 43431 & -3 & -75 & 5 & 2 & -5 & -.1 & .01 \\
\hline 73 & $300 \mathrm{~W}-300 \mathrm{~N}$ & 43522 & -3 & -75 & 5 & 8 & -5 & -.1 & .01 \\
\hline 74 & $100 \mathrm{~W}-300 \mathrm{~N}$ & 43488 & 6 & -75 & 10 & 4 & -5 & -.1 & .02 \\
\hline 75 & $0 W-300 N$ & 43438 & 11 & -50 & 10 & 1 & -3 & .0160 & .0233 \\
\hline 75 & OW-300N & 43532 & 273 & I. S. & -15 & 5 & -15 & -.2 & .03 \\
\hline 76 & $25 \mathrm{E}-300 \mathrm{~N}$ & 43459 & 42 & -75 & 20 & 5 & 5 & 0.1 & .02 \\
\hline 77 & $100 \mathrm{E}-300 \mathrm{~N}$ & 43666 & -6 & I.S. & 80 & 9 & -10 & -.1 & .02 \\
\hline 78 & USOOE-300N & 43681 & -3 & -75 & 25 & 4 & 10 & -.1 & .02 \\
\hline 78 & $500 \mathrm{E}-\mathrm{ON}$ & 43667 & -12 & I.S. & 70 & 8 & -10 & 0.3 & .02 \\
\hline 79 & $700 \mathrm{E}-300 \mathrm{~N}$ & 43670 & -3 & -75 & 35 & 6 & -5 & 0.3 & .007 \\
\hline 80 & $900 \mathrm{E}-300 \mathrm{~N}$ & 43503 & -2 & -50 & -3 & 8 & -3 & -.1 & .009 \\
\hline 80 & $900 \mathrm{E}-300 \mathrm{~N}$ & 43531 & -6 & -150 & -10 & 10 & -10 & -.1 & .03 \\
\hline 81 & AT-9 & 43517 & -2 & -50 & 13 & 1 & 7 & -.1 & .01 \\
\hline 82 & AT -10 & 43495 & -3 & -75 & 20 & 5 & -5 & 0.3 & .02 \\
\hline 83 & $150 \mathrm{~W}-250 \mathrm{~N}$ & 43512 & 5 & -75 & 10 & 3 & -5 & -.1 & .02 \\
\hline 84 & $500 \mathrm{~W}-200 \mathrm{~N}$ & 43453 & -2 & -37 & -3 & 1 & -3 & -.1 & .006 \\
\hline 85 & $100 \mathrm{~W}-200 \mathrm{~N}$ & 43493 & 12 & -75 & 10 & 5 & -5 & -.1 & .02 \\
\hline 87 & $35 \mathrm{E}-200 \mathrm{~N}$ & 43457 & 35 & -50 & 3 & 3 & -3 & -.1 & .01 \\
\hline 88 & U300E-200N & 43433 & -1 & -30 & 13 & -1 & -3 & .0140 & .0266 \\
\hline 91 & $50 \mathrm{E}-150 \mathrm{~N}$ & 43458 & 155 & -50 & 16 & 3 & 3 & -.1 & .01 \\
\hline 94 & U300W-100N & 43470 & -2 & -37 & -3 & 1 & -3 & -.1 & .005 \\
\hline 95 & $100 \mathrm{~W}-100 \mathrm{~N}$ & 43487 & 6 & -150 & 50 & 13 & -10 & -.1 & .04 \\
\hline 96 & OW-100N & 43527 & 43 & -75 & 20 & 6 & 5 & -.1 & .06 \\
\hline 97 & $O E-100 N$ & 43442 & 53 & -50 & 16 & 3 & 7 & .17 & .02 \\
\hline
\end{tabular}


Table 4 (Contd)

\begin{tabular}{|c|c|c|c|c|c|c|c|c|c|}
\hline $\begin{array}{l}\text { Map } \\
\text { No. }\end{array}$ & $\begin{array}{c}\text { Bield } \\
\text { No. }\end{array}$ & $\begin{array}{c}\text { Analytical } \\
\text { Code No. }\end{array}$ & $\begin{array}{c}U \\
\text { pp!n }\end{array}$ & $\begin{array}{c}V \\
\text { gpm }\end{array}$ & $\begin{array}{l}\text { Mo } \\
\text { ppm }\end{array}$ & $\begin{array}{l}\text { As } \\
\text { ppm }\end{array}$ & $\begin{array}{l}\mathrm{Cu} \\
\mathrm{Pp}\end{array}$ & $\begin{array}{r}\mathrm{Mn} \\
\%\end{array}$ & $\begin{array}{r}\mathrm{Zn} \\
\% \\
\end{array}$ \\
\hline 97 & $\mathrm{OE}-100 \mathrm{~N}$ & 43684 & 36 & I.S. & 45 & 15 & 95 & 1.07 & .11 \\
\hline 98 & 100E-100N & 43671 & 42 & -75 & 40 & 7 & -5 & -.10 & .01 \\
\hline 98 & $100 \mathrm{E}-100 \mathrm{~N}$ & 43473 & 91 & -75 & 5 & 5 & -5 & -.1 & .02 \\
\hline 99 & U500E-.100N & 43524 & -2 & -50 & -3 & 5 & -3 & -.1 & .006 \\
\hline 100 & $9008-100 \mathrm{~N}$ & 43672 & -3 & -75 & 40 & 3 & -5 & 0.35 & .006 \\
\hline 100 & $900 E-100 \mathrm{~N}$ & 43464 & -2 & -50 & 4 & 1 & -3 & -.1 & .01 \\
\hline 102 & LOOW-ON & 43449 & -2 & -50 & 10 & -1 & -3 &,- 1 & -.01 \\
\hline 103 & U300E-ON & 43455 & -3 & -75 & -5 & 7 & -5 & -.1 & .01 \\
\hline 104 & $500 \mathrm{E}-\mathrm{ON}$ & 43504 & -2 & -37 & -3 & 5 & -3 & -.1 & .007 \\
\hline 104 & 500E-ON & 43516 & -1 & -30 & 6 & 10 & -2 & -.1 & .006 \\
\hline 105 & U7OOE-ON & 43525 & -3 & -75 & 10 & 7 & -5 & -.1 & .02 \\
\hline 105 & $700 \mathrm{E}-\mathrm{ON}$ & 43669 & -12 & -150 & 20 & 12 & -10 & 0.5 & .02 \\
\hline 1.07 & $200 \mathrm{E}-50 \mathrm{~s}$ & 43514 & 4 & -75 & 20 & -1 & -5 & -.1 & .01 \\
\hline 108 & $O E-100 S$ & 43439 & 17 & -75 & -5 & 2 & -5 & .021 & .0250 \\
\hline 109 & $200 \mathrm{E}-100 \mathrm{~s}$ & 43511 & 26 & -75 & 10 & -1 & -5 & -.1 & .01 \\
\hline 111 & $900 E-100 S$ & 43446 & -2 & -50 & 10 & -1 & -3 & -.1 & .01 \\
\hline 112 & $100 E-200 S$ & 43468 & 12 & -50 & 7 & 1 & 3 & -.1 & .01 \\
\hline 113 & $300 E-200 S$ & 43494 & 2 & -50 & 3 & 3 & -3 & -.1 & .01 \\
\hline 114 & $900 \mathrm{~L}-200 \mathrm{~S}$ & 43471 & -2 & -50 & 7 & 1 & -3 & -.1 & .01 \\
\hline 115 & $O E-300 S$ & 43462 & 15 & -50 & 7 & 1 & -3 & -.1 & .01 \\
\hline 116 & $100 \mathrm{E}-300 \mathrm{~S}$ & 43434 & 18 & -75 & 15 & 3 & -5 & .0240 & .0500 \\
\hline 1.16 & $100 \mathrm{E}-300 \mathrm{~s}$ & 43665 & -6 & I.S. & 40 & 17 & -10 & 0.40 & .04 \\
\hline 116 & ID100E-300S & 43668 & -120 & I.S. & 95 & 40 & -15 & -.7 & .02 \\
\hline 117 & $200 \mathrm{E}-300 \mathrm{~S}$ & 43496 & 26 & -75 & 5 & 9 & -5 &,- 1 & .02 \\
\hline 118 & $200 E-400 S$ & 43509 & -3 & -75 & -5 & 2 & -5 & -.1 & .02 \\
\hline 121 & $O E-500 S$ & 43478 & 18 & -75 & 10 & 2 & -5 &,- 1 & .02 \\
\hline 122 & $50 E-500 S$ & 43481 & -12 & $I, S$, & -20 & 2 & -20 & -.1 & .05 \\
\hline 122 & U50E-500S & 43505 & -2 & -50 & 13 & 2 & -3 & -.1 & .008 \\
\hline 124 & $O E-600 S$ & 43443 & 5 & -50 & 10 & 2 & 7 & -.10 & .01 \\
\hline 126 & OE-700S & 43506 & 4 & -75 & 5 & 2 & -5 & -.1 & .01 \\
\hline 127 & OE-800S & 43432 & -3 & -50 & 10 & -1 & -3 & .0103 & .0233 \\
\hline 128 & $100 E-800 S$ & 43452 & 22 & -50 & 7 & -1 & -3 & -.1 & .007 \\
\hline 129 & $0 E-900 S$ & 43440 & -3 & -75 & 5 & 6 & -5 & -.1 & .01 \\
\hline 130 & $100 \mathrm{E}-900 \mathrm{~S}$ & 43451 & -2 & -37 & 5 & 1 & -3 & -.1 & .006 \\
\hline 133 & OE-1000S & 43510 & -12 & I.S, & -5 & 1 & -5 & -.1 & .03 \\
\hline 134 & $100 E-1000 S$ & 43447 & -3 & -75 & 35 & 1 & -5 & -.1 & .01 \\
\hline 138 & $\mathrm{OE}-1100 \mathrm{~S}$ & 43445 & -6 & -150 & -10 & 2 & -10 & .50 & .01 \\
\hline 139 & $100 \mathrm{E}-1100 \mathrm{~S}$ & 43460 & -3 & -75 & 10 & 5 & -5 & 0.7 & .02 \\
\hline
\end{tabular}


Table 5

Western Hemlock

Ash Analyses

\begin{tabular}{|c|c|c|c|c|c|c|c|c|c|}
\hline $\begin{array}{l}\text { Map } \\
\text { No. }\end{array}$ & $\begin{array}{c}\text { Field } \\
\text { No. }\end{array}$ & $\begin{array}{c}\text { Analytical } \\
\text { Code No. }\end{array}$ & $\begin{array}{c}U \\
\text { ppm }\end{array}$ & $\begin{array}{c}\text { V } \\
\text { ppm }\end{array}$ & $\begin{array}{l}\text { Mo } \\
\text { ppm }\end{array}$ & $\begin{array}{l}\text { As } \\
\text { PpQ }\end{array}$ & $\begin{array}{l}\mathrm{Cu} \\
\mathrm{ppm}\end{array}$ & $\begin{array}{r}\mathrm{Mn} \\
\% \\
\end{array}$ & $\begin{array}{r}\mathrm{Zn} \\
\% \\
\end{array}$ \\
\hline 1 & $100 \mathrm{~W}-1300 \mathrm{~N}$ & 43605 & 121 & -150 & -10 & -1 & -10 & 8.20 & .04 \\
\hline 2 & $100 \mathrm{~W}-1200 \mathrm{~N}$ & 43583 & -6 & -150 & -10 & 4 & -10 & 10.90 & .03 \\
\hline 5 & $100 \mathrm{~W}-1100 \mathrm{~N}$ & 43585 & -6 & -150 & -10 & 8 & -10 & 9.10 & .03 \\
\hline 16 & U300E-1000N & 43587 & -3 & -75 & -5 & 7 & -5 & 7.15 & .01 \\
\hline 17 & U500E-100ON & 43581 & -3 & -75 & 20 & 5 & -5 & 4.10 & .01 \\
\hline 20 & $100 \mathrm{~W}-900 \mathrm{~N}$ & 43593 & -3 & -75 & 35 & 4 & -5 & 6.45 & .007 \\
\hline 21 & OW $-900 \mathrm{~N}$ & 43575 & -6 & -150 & -10 & 7 & -10 & 1.70 & .02 \\
\hline 22 & $100 \mathrm{E}-900 \mathrm{~N}$ & 43602 & -6 & -150 & -10 & -1 & 10 & 5.70 & .04 \\
\hline 27 & $\mathrm{AT}-8$ & 43582 & -20 & I.S. & -13 & 14 & -13 & 7.67 & .03 \\
\hline 28 & $\mathrm{AT}-7$ & 43578 & -6 & -150 & 20 & 117 & -10 & 3.90 & .02 \\
\hline 29 & AT $\sim 6$ & 43601 & -6 & -150 & 10 & -1 & 40 & 3.20 & .02 \\
\hline 30 & $A T-6$ & 43621 & -20 & I.S. & 13 & 9 & 35 & 4.00 & .03 \\
\hline 36 & U500E-800N & 43600 & -6 & -150 & 10 & -1 & 30 & 3.20 & .06 \\
\hline 44 & $500 \mathrm{~W}-600 \mathrm{~N}$ & 43577 & -6 & -150 & 10 & -1 & -10 & 5.40 & .02 \\
\hline 46 & U300E-600N & 43615 & -6 & -150 & 10 & 3 & -10 & 6.40 & .05 \\
\hline 48 & $500 \mathrm{~W}-500 \mathrm{~N}$ & 43616 & -6 & -150 & -10 & -1 & 10 & 8.60 & .03 \\
\hline 49 & $400 \mathrm{~W}-500 \mathrm{~N}$ & 43592 & -3 & -75 & -5 & 1 & -5 & 6.40 & .01 \\
\hline 56 & $500 \mathrm{E}-600 \mathrm{~N}$ & 43607 & -6 & -150 & -10 & -1 & -10 & 4.10 & .02 \\
\hline 59 & $\mathrm{AT}-4$ & 43597 & -6 & -15 & 40 & -1 & -10 & 3.50 & .02 \\
\hline 60 & AT -5 & 43589 & -6 & -150 & 10 & -1 & -10 & 5.20 & .02 \\
\hline 61 & $\mathrm{AT}-2$ & 43590 & -6 & -150 & -10 & -1 & -10 & 6.00 & .02 \\
\hline 65 & At -1 & 43599 & -6 & -50 & 40 & -1 & 10 & 5.60 & .02 \\
\hline 66 & AT -3 & 43611 & -6 & -150 & 50 & 10 & -10 & 6.80 & .02 \\
\hline 67 & $500 \mathrm{~W}-400 \mathrm{~N}$ & 43613 & -3 & -75 & -5 & 3 & -5 & 3.85 & .01 \\
\hline 69 & $200 \mathrm{E}-400 \mathrm{~N}$ & 43594 & 48 & -150 & 90 & 4 & 35 & 9.00 & .04 \\
\hline 70 & U300E-400N & 43595 & -3 & $-7 s$ & -5 & -1 & 5 & 8.35 & .006 \\
\hline 71 & $500 \mathrm{E}-400 \mathrm{~N}$ & 43574 & -6 & -150 & -10 & 113 & -10 & 3.90 & .02 \\
\hline 73 & U300W-300N & 43619 & -20 & I.S. & 25 & 11 & 45 & 8.25 & .06 \\
\hline 74 & $100 \mathrm{~W}-300 \mathrm{~N}$ & 43603 & 32 & -150 & -10 & -1 & 10 & 3.70 & .05 \\
\hline 78 & $\mathrm{U} 500 \mathrm{E}-300 \mathrm{~N}$ & 43580 & -6 & -150 & 40 & 5 & -10 & 5,00 & .02 \\
\hline 79 & U700E-300N & 43606 & -2 & -50 & -3 & -1 & 13 & 5.00 & .02 \\
\hline 82 & AT-10 & 43579 & -6 & -150 & -10 & 7 & -10 & 6.90 & .02 \\
\hline 83 & $150 \mathrm{~W}-250 \mathrm{~N}$ & 43620 & 189 & -150 & 23 & 8 & 55 & 4.56 & .05 \\
\hline 87 & $35 \mathrm{E}-200 \mathrm{~N}$ & 43614 & 523 & -150 & 10 & 125 & 40 & 8,40 & .04 \\
\hline 96 & $O E-100 \mathrm{~N}$ & 43604 & -6 & -150 & -10 & -1 & -10 & 6.80 & .02 \\
\hline 98 & $100 \mathrm{E}-100 \mathrm{~N}$ & 43576 & 129 & -150 & -10 & 7 & -10 & 7.90 & .03 \\
\hline 100 & $900 \mathrm{E}-100 \mathrm{~N}$ & 43586 & -3 & -75 & 20 & 9 & 10 & 7.05 & .02 \\
\hline 102 & $100 \mathrm{~W}-0 \mathrm{~N}$ & 43588 & -6 & -150 & -10 & -1 & -10 & 6.70 & .60 \\
\hline 103 & U300E-ON & 43617 & 28 & -150 & -10 & 2 & 10 & 4.20 & .08 \\
\hline 105 & U7OOE-ON & 43610 & -6 & -150 & 30 & 10 & -10 & 8,10 & .02 \\
\hline
\end{tabular}


Table 5 (Contd)

\begin{tabular}{|c|c|c|c|c|c|c|c|c|c|}
\hline $\begin{array}{l}\text { Map } \\
\text { No, }\end{array}$ & $\begin{array}{l}\text { Field } \\
\text { No. }\end{array}$ & $\begin{array}{l}\text { Analytical } \\
\text { Code No. }\end{array}$ & $\begin{array}{c}\mathrm{U} \\
\mathrm{ppm} \\
\end{array}$ & $\begin{array}{c}V \\
\mathrm{Ppm} \\
\end{array}$ & $\begin{array}{l}\text { Mo } \\
\text { epm }\end{array}$ & $\begin{array}{l}\text { As } \\
\text { Ppm }\end{array}$ & $\begin{array}{l}\mathrm{Cu} \\
\mathrm{PPm}\end{array}$ & $\begin{array}{r}\text { Mn } \\
\% \\
\end{array}$ & $\begin{array}{r}2 n \\
\% \\
\end{array}$ \\
\hline 111 & $900 \mathrm{E}-100 \mathrm{~S}$ & 43598 & -2 & -50 & 10 & -1 & 3 & 5.97 & .008 \\
\hline 114 & $900 \mathrm{E}-200 \mathrm{~S}$ & 43596 & -6 & -15 & 40 & -1 & 10 & 9.80 & .02 \\
\hline 117 & $200 \mathrm{E}-300 \mathrm{~S}$ & 43591 & -20 & I, S, & -20 & -1 & -20 & 7.83 & .06 \\
\hline 122 & U50E-500S & 43618 & 85 & I.S. & -50 & 30 & -50 & 6.00 & .08 \\
\hline 122 & ID50E-500S & 43612 & 901 & -150 & -10 & 9 & 20 & 4.70 & .04 \\
\hline 129 & OE-90OS & 43609 & -3 & 75 & 15 & -1 & 20 & 6.25 & .02 \\
\hline 133 & OE-1000S & 43584 & -6 & -150 & 30 & 5 & -10 & 13.80 & .04 \\
\hline 139 & $100 E-1100 S$ & 43608 & -3 & 75 & -5 & -1 & 5 & 6.10 & .01 \\
\hline
\end{tabular}

Table 6

Junlper

Ash Analyses

\begin{tabular}{|c|c|c|c|c|c|c|c|c|c|}
\hline $\begin{array}{l}\text { Map } \\
\text { No. }\end{array}$ & $\begin{array}{c}\text { Field } \\
\text { No. }\end{array}$ & $\begin{array}{c}\text { Analytical } \\
\text { Code No. }\end{array}$ & $\begin{array}{c}U \\
\mathrm{PP} \\
\end{array}$ & $\begin{array}{c}V \\
\text { ppm }\end{array}$ & $\begin{array}{l}\text { Mo } \\
\mathrm{PPm}\end{array}$ & $\begin{array}{l}\text { As } \\
\text { ppm }\end{array}$ & $\begin{array}{l}\mathrm{Cu} \\
\mathrm{ppm}\end{array}$ & $\begin{array}{r}M n \\
\% \\
\end{array}$ & $\begin{array}{r}\mathrm{Zn} \\
\%\end{array}$ \\
\hline 5 & $100 \mathrm{~W}-1100 \mathrm{~N}$ & 43637 & -2 & -50 & 7 & 1 & 10 & 0.27 & .01 \\
\hline 12 & $100 \mathrm{~W}-1000 \mathrm{~N}$ & 43636 & -6 & -150 & 10 & 14 & -10 & 0.30 & .02 \\
\hline 21 & OW-90ON & 43627 & -6 & -150 & -100 & 9 & -100 & 1,3 & .03 \\
\hline 51 & $100 \mathrm{~W}-500 \mathrm{~N}$ & 43635 & -6 & -150 & 30 & 27 & -10 & 1.60 & .02 \\
\hline 73 & $100 \mathrm{~W}-300 \mathrm{~N}$ & 43633 & -3 & -75 & 25 & 6 & 15 & 0.50 & .02 \\
\hline 74 & $100 W-100 \mathrm{~N}$ & 43626 & 20 & -75 & 5 & 3 & 15 & 0.05 & .02 \\
\hline 75 & $25 \mathrm{E}-300 \mathrm{~N}$ & 43622 & 6 & -75 & 10 & -1 & -5 & 0.80 & .01 \\
\hline 83 & $250 \mathrm{~W}-250 \mathrm{~N}$ & 43634 & 159 & -150 & 10 & 17 & -10 & 1.20 & .02 \\
\hline 85 & $200 \mathrm{~W}-200 \mathrm{~N}$ & 43624 & 27 & -150 & -10 & 18 & -10 & 0.60 & .02 \\
\hline 87 & $35 \mathrm{E}-200 \mathrm{~N}$ & 43625 & 136 & -150 & -10 & 11 & 10 & 1,80 & .02 \\
\hline 91 & $50 E-150 N$ & 43628 & 15 & -75 & 10 & 4 & 10 & 0.65 & .03 \\
\hline 96 & OW-100N & 43631 & 80 & -75 & 35 & 9 & 25 & 0.95 & .03 \\
\hline 98 & $100 \mathrm{E}-100 \mathrm{~N}$ & 43640 & 75 & -150 & 20 & 13 & -10 & 1.70 & .02 \\
\hline 107 & $200 E-50 S$ & 43632 & -6 & -150 & -10 & 12 & -10 & 1.10 & .02 \\
\hline 109 & $200 E-100 S$ & 43639 & 11 & -75 & 35 & 8 & 5 & 0.70 & .02 \\
\hline 112 & $100 E-200 S$ & 43630 & 13 & -75 & 10 & 3 & 10 & 1.00 & .02 \\
\hline 127 & $200 E-300 S$ & 43638 & 61 & -75 & 15 & 8 & 15 & 1,00 & .04 \\
\hline 117 & $300 E-200 s$ & 43629 & 5 & -75 & -5 & 2 & 5 & 0.45 & .02 \\
\hline 119 & $300 E-400 s$ & 43623 & 68 & -75 & 5 & 7 & 25 & 1.25 & .04 \\
\hline
\end{tabular}


Table 7

Blueberry

Ash Analyses

\begin{tabular}{|c|c|c|c|c|c|c|c|c|c|}
\hline $\begin{array}{l}\text { Map } \\
\text { No. }\end{array}$ & $\begin{array}{l}\text { Field } \\
\text { No. }\end{array}$ & $\begin{array}{l}\text { Analytical } \\
\text { Code No. }\end{array}$ & $\begin{array}{c}\mathrm{U} \\
\text { ppm }\end{array}$ & $\begin{array}{c}\mathrm{V} \\
\mathrm{pom} \\
\end{array}$ & $\begin{array}{l}\text { Mo } \\
\text { ppm }\end{array}$ & $\begin{array}{l}\text { As } \\
\mathrm{ppm}\end{array}$ & $\begin{array}{l}\mathrm{Cu} \\
\mathrm{ppm}\end{array}$ & $\begin{array}{r}M n \\
\% \\
\end{array}$ & $\begin{array}{r}\mathrm{Zn} \\
\% \\
\end{array}$ \\
\hline 27 & AT8 & 43655 & -20 & I.S. & -20 & 4 & 60 & 8.20 & .05 \\
\hline 28 & $\operatorname{AT} 7$ & 43657 & -30 & I.S. & -20 & 13 & 20 & 6.75 & .06 \\
\hline 29 & AT6 & 43656 & -20 & I.S. & 80 & 6 & 40 & 5.00 & .03 \\
\hline 30 & $\mathrm{~A} 16-\mathrm{B} 2$ & 43659 & -20 & I.S. & -20 & 6 & 40 & 2.40 & .05 \\
\hline 50 & U300W-500N & 43647 & -20 & I.S. & 14 & 3 & 40 & 4.14 & .05 \\
\hline 55 & $100 E-500 N$ & 43658 & -20 & I.S. & 25 & 3 & -15 & 9.00 & .04 \\
\hline 59 & $\mathrm{AT} 4$ & 43649 & -20 & $I, S$. & -20 & 2 & 80 & 3.60 & .06 \\
\hline 60 & AT5 & 43645 & -20 & -150 & -10 & 6 & 140 & 5.89 & .06 \\
\hline 61 & $\Lambda \mathrm{T} 2$ & 43648 & -20 & -150 & 24 & 2 & 125 & 5.78 & .05 \\
\hline 65 & $\mathrm{AT}-1$ & 43642 & -20 & I.S. & 33 & 6 & 80 & 1.13 & .04 \\
\hline 66 & AT3 & 43652 & -20 & $I, S$. & 35 & 8 & 55 & 7.50 & .04 \\
\hline 69 & $200 \mathrm{E}-400 \mathrm{~N}$ & 43651 & -20 & I.S. & -20 & 21 & 60 & 6.17 & .04 \\
\hline 70 & $\mathrm{U} 300 \mathrm{E}-400 \mathrm{~N}$ & 43654 & -30 & I. S. & 98 & 19 & -25 & 7.25 & .05 \\
\hline 73 & U $300 \mathrm{~W}-300 \mathrm{~N}$ & 43646 & -20 & -150 & 55 & 5 & 35 & 5.44 & .04 \\
\hline 77 & U100E-300N & 43644 & -20 & I.S. & -12 & 4 & 12 & 5.38 & .04 \\
\hline 81 & $A^{\prime} I^{\prime} 9$ & 43643 & -20 & I. S. & 14 & 7 & 90 & 3.33 & .06 \\
\hline 83 & $150 \mathrm{~W}-250 \mathrm{~N}$ & 43641 & 30 & I.S. & -12 & 11 & 85 & 8.67 & .05 \\
\hline 122 & $50 E-500 S$ & 43653 & 15 & I.S. & 95 & 9 & 75 & 5.75 & .06 \\
\hline 122 & U50:-500S & 43650 & -30 & I.S. & -30 & 12 & -30 & 1.50 & .03 \\
\hline
\end{tabular}

Table 8

Algae

Ash Analyses

\begin{tabular}{|c|c|c|c|c|c|c|c|c|c|}
\hline $\begin{array}{l}\text { Map } \\
\text { No, }\end{array}$ & $\begin{array}{c}\text { Field } \\
\text { No. }\end{array}$ & $\begin{array}{c}\text { Analytical } \\
\text { Code No. }\end{array}$ & $\begin{array}{c}\mathrm{U} \\
\mathrm{Ppm}\end{array}$ & $\begin{array}{c}V \\
\mathrm{pPm}\end{array}$ & $\begin{array}{l}\text { Mo } \\
\mathrm{ppm}\end{array}$ & $\begin{array}{l}\text { As } \\
\mathrm{ppm}\end{array}$ & $\begin{array}{l}\mathrm{Cu} \\
\mathrm{ppm}\end{array}$ & $\begin{array}{r}M n \\
\% \\
\end{array}$ & $\begin{array}{r}\text { Zn } \\
\% \\
\end{array}$ \\
\hline 6 & AOW-11N & 43746 & 16 & -75 & -50 & 3 & -50 & 0.50 & -.001 \\
\hline 10 & $\mathrm{~A} 4 \mathrm{~W}-10 \mathrm{~N}$ & 43752 & 2 & -30 & -2 & -1 & -2 &,- 1 & -.001 \\
\hline 11 & $A 2 W-10 N$ & 43751 & 63 & 60 & -2 & 3 & 2 & -.1 & -.001 \\
\hline 12 & $A I W-10 N$ & 43748 & 173 & $I, S$. & -30 & 3 & -30 & 1.00 & .02 \\
\hline 13 & AOW-10N & 43745 & 47 & -30 & 14 & -1 & 4 & 0.84 & .003 \\
\hline 21 & $A O W-9 N$ & 43744 & 51 & -75 & 10 & -1 & -5 & 3,95 & .24 \\
\hline 37 & AOW $-7 N-2$ & 43743 & 770 & -30 & 8 & 4 & & -.1 & .001 \\
\hline 39 & $A 1 W-7 N$ & 43747 & 1833 & -30 & 14 & 2 & -2 & 1,74 & .09 \\
\hline 40 & AOW-7N-1 & 43742 & 662 & -50 & 13 & 7 & 3 & .2 & .02 \\
\hline
\end{tabular}


Table 8 (Contd)

\begin{tabular}{|c|c|c|c|c|c|c|c|c|c|}
\hline $\begin{array}{l}\text { Map } \\
\text { No. }\end{array}$ & $\begin{array}{c}\text { Field } \\
\text { No. }\end{array}$ & $\begin{array}{c}\text { Analytical } \\
\text { Code No. }\end{array}$ & $\begin{array}{c}U \\
\text { ppin }\end{array}$ & $\begin{array}{c}V \\
\text { ppm }\end{array}$ & $\begin{array}{l}\text { Mo } \\
\text { ppm }\end{array}$ & $\begin{array}{l}\text { As } \\
\mathrm{ppm}\end{array}$ & $\begin{array}{l}\mathrm{Cu} \\
\mathrm{ppm}\end{array}$ & $\begin{array}{r}\mathrm{Mn} \\
\% \\
\end{array}$ & $\begin{array}{r}\mathrm{Zn} \\
\% \\
\end{array}$ \\
\hline 135 & A.l & 43740 & 14 & I.S. & -20 & 37 & -20 & -.2 & .006 \\
\hline 139 & A1E-11S & 43750 & 28 & -150 & -10 & 1 & -10 & 0.50 & .009 \\
\hline * & A2 & 43741 & 5 & -50 & -3 & 24 & -3 & -.1 & .01 \\
\hline$* x$ & $A K B-2$ & 43749 & -20 & I.S. & -15 & 1 & -15 & -.2 & .007 \\
\hline
\end{tabular}

* Sample location -- near Kendricik Bay Camp -- not shown on map

** Sample location -- west end of Kendrick Bay - not shown on map

Table 9

Miscellaneous Plants

Ash Analyses

\begin{tabular}{|c|c|c|c|c|c|c|c|c|c|c|}
\hline $\begin{array}{l}\text { Map } \\
\text { No. }\end{array}$ & $\begin{array}{l}\text { Field } \\
\text { No. }\end{array}$ & & $\begin{array}{l}\text { nalytical } \\
\text { Code No. }\end{array}$ & $\begin{array}{c}\mathrm{U} \\
\mathrm{ppm}\end{array}$ & $\begin{array}{c}V \\
\text { ppm }\end{array}$ & $\begin{array}{l}\text { Mo } \\
\text { ppm }\end{array}$ & $\begin{array}{l}\text { As } \\
\mathrm{ppm}\end{array}$ & $\begin{array}{l}\mathrm{Cu} \\
\mathrm{ppm}\end{array}$ & $\begin{array}{r}\mathrm{Mn} \\
\% \\
\end{array}$ & $\begin{array}{r}2 \mathrm{n} \\
\% \\
\end{array}$ \\
\hline 24 & $300 \mathrm{E}-900 \mathrm{~N}$ & A & 43660 & -20 & -150 & 75 & 8 & 45 & 0.33 & .03 \\
\hline 32 & $100 W-800 N$ & $\underline{U}$ & 43687 & -20 & -150 & 45 & 7 & 35 & 2.44 & .057 \\
\hline 32 & $100 \mathrm{~W}-800 \mathrm{~N}$ & $\overline{\mathrm{A}}$ & 43663 & -6 & -150 & 70 & 15 & 20 & 1.70 & .09 \\
\hline 51 & $100 \mathrm{~W}-500 \mathrm{~N}$ & $\underline{\bar{U}}$ & 43688 & -3 & -75 & 35 & 4 & 5 & -.1 & .02 \\
\hline 53 & $0 W-500 \mathrm{~N}$ & $\underline{\bar{A}}$ & 43664 & -6 & -150 & 120 & 9 & 40 & 0.70 & .06 \\
\hline 57 & $700 \mathrm{E}-500 \mathrm{~N}$ & A & 43662 & -6 & -150 & 130 & 5 & 90 & 0.80 & .09 \\
\hline 76 & $25 \mathrm{E}-300 \mathrm{~N}$ & $\underline{\mathrm{T}}$ & 43679 & 374 & -150 & 80 & 5 & 10 & 0.80 & .04 \\
\hline 81 & AT9 & $\underline{\bar{M} 2}$ & 43676 & -20 & I.S. & -15 & 5 & 65 & 2.01 & .04 \\
\hline 81 & AT9 & $\underline{T}$ & 43680 & -20 & I, S, & -20 & 25 & 13 & 1,67 & .05 \\
\hline 87 & $35 \mathrm{E}-200 \mathrm{~N}$ & $\underline{\bar{M}}$ & 43675 & 923 & -150 & 70 & 19 & 60 & 1.60 & .08 \\
\hline 95 & $100 \mathrm{~W}-100 \mathrm{~N}$ & $\underline{M 2}$ & 43677 & 832 & I.S, & -20 & 2 & 140 & 4.00 & .05 \\
\hline 107 & $200 \mathrm{E}-50 \mathrm{~S}$ & $\underline{\mathrm{M} 2}$ & 43678 & 119 & I, S, & -15 & 4 & 130 & 4.25 & .06 \\
\hline 117 & $300 E-300 S$ & $\underline{A}$ & 43661 & -6 & -150 & 80 & 5 & 30 & 0.70 & .07 \\
\hline
\end{tabular}


Table 10

Mulch and Soll Analyses

\begin{tabular}{|c|c|c|c|c|c|c|c|c|c|}
\hline $\begin{array}{l}\text { Map } \\
\text { No. }\end{array}$ & $\begin{array}{c}\text { Field } \\
\text { No. }\end{array}$ & $\begin{array}{c}\text { Analytical } \\
\text { Code No. }\end{array}$ & $\begin{array}{c}\mathrm{U} \\
\mathrm{ppin} \\
\end{array}$ & $\begin{array}{c}\mathrm{V} \\
\mathrm{ppm} \\
\end{array}$ & $\begin{array}{l}\text { Mo } \\
\text { ppm }\end{array}$ & $\begin{array}{l}\text { As } \\
\text { ppm }\end{array}$ & $\begin{array}{l}\mathrm{Cu} \\
\mathrm{ppm}\end{array}$ & $\begin{array}{r}\mathrm{Mn} \\
\% \\
\end{array}$ & $\begin{array}{r}2 n \\
\%\end{array}$ \\
\hline 1 & $M 1 W-13 N$ & M 43693 & 109 & I.S. & 23 & 27 & 35 & 0.57 & \\
\hline 2 & $M 1 W-12 N$ & M 43694 & 7 & -37 & 20 & 5 & 15 &,- 1 & \\
\hline 6 & COL $-11 N$ & $\bar{M} 43716$ & -1 & -30 & 10 & 4 & -2 & -.1 & .004 \\
\hline 14 & MIE-1ON & $\bar{M} 43692$ & 229 & -75 & 40 & 11 & 20 & 2.05 & .03 \\
\hline 19 & $M 2 W-9 N$ & $\underline{M} 43695$ & 30 & -30 & 60 & 6 & 160 & .1 & \\
\hline 20 & $M 1 W-9 N$ & M 43725 & 47 & -75 & -5 & 6 & 20 & -.1 & .004 \\
\hline 22 & $M 1 E-9 N$ & $\bar{M} 43713$ & 6 & -50 & 3 & 7 & -3 & -.1 & \\
\hline 27 & $\mathrm{AT}-8 \mathrm{M}$ & $\underline{\bar{M}} 43718$ & -20 & $I . S$. & -15 & 9 & -15 & .2 & .009 \\
\hline 28 & $\triangle \mathrm{T}-7 \mathrm{M}$ & $\underline{\bar{M}} 43717$ & -1 & -30 & -2 & J. 2 & -2 & -.1 & .005 \\
\hline 29 & $A T-6 M$ & $\underline{\bar{M}} 43690$ & -6 & -1.50 & -10 & 12 & -10 & 0.1 & .02 \\
\hline 30 & AT $6-M 2$ & M 43710 & 114 & -30 & 16 & -1 & 12 & .2 & \\
\hline 31 & $2 W-8 N$ & $\bar{M} 43699$ & 7 & -30 & -2 & 4 & -2 & -.11 & \\
\hline 34 & $M 1 E-8 N$ & $\underline{M} 43712$ & 42 & -150 & -10 & 16 & 50 &, 1 & \\
\hline 44 & $S 5 W-6 \mathrm{~N}$ & $\underline{\bar{M}} 43715$ & 12 & -30 & 14 & 5 & -2 & -.1 & .003 \\
\hline 48 & $S 5 W-5 N$ & $\underline{\mathrm{S}} 43739$ & 3 & -30 & -3 & 1 & -3 & -.1 & .003 \\
\hline 49 & $S 4 W-5 N$ & S 43738 & 11 & -30 & -2 & 2 & -2 & -.1 & .003 \\
\hline 55 & $M I L-5 N$ & $\underline{\bar{M}} 43723$ & 441 & -150 & -10 & 23 & 70 & -.1 & .01 \\
\hline 59 & AT4-M & $\underline{\bar{M}} 43701$ & 13 & -50 & 7 & -1 & 20 & .2 & \\
\hline 60 & AT5-M & $\bar{M} 43709$ & 15 & -150 & -10 & 25 & 40 & 1 & \\
\hline 61 & AT2-M & $\underline{\bar{M}} 43707$ & 12 & -37 & 7 & -1 & 5 & -1 & \\
\hline 65 & $\Lambda T-1 M$ & $\underline{M} 43697$ & 19 & -50 & -3 & 11 & 15 & .2 & \\
\hline 66 & $\mathrm{AT}-3 \mathrm{M}$ & $\bar{M} 43698$ & -20 & I.S. & -15 & 15 & 25 & 1.45 & \\
\hline 67 & $55 W-4 N$ & $\underline{M} 43706$ & 93 & -150 & -10 & 323 & 40 & .3 & \\
\hline 72 & SSW-3N & $\underline{\bar{S}} 43737$ & 2 & -30 & -3 & 2 & -3 & -.1 & .007 \\
\hline 77 & $M \perp E-3 N$ & $\bar{M} 43691$ & 110 & -30 & 12 & 4 & 4 &,- 1 & .001 \\
\hline 81 & $\mathrm{AT}-9 \mathrm{M}$ & $M 43719$ & 3 & -30 & 18 & 4 & 10 & -.1 & .004 \\
\hline 82 & $A T-1 O M$ & $\underline{M} 43720$ & -20 & I.S. & -15 & 6 & 35 & .2 & .009 \\
\hline 84 & $S 5 W-2 N$ & $\underline{\underline{S}} 43736$ & 5 & & 2 & 16 & -2 & -.1 & .003 \\
\hline 107 & S200E-50S & $\underline{M} 43705$ & 22 & -30 & -2 & 2 & -2 & -.1 & \\
\hline 127 & MOE-80OS & $\underline{\bar{M}} 43722$ & 12 & -30 & 20 & 6 & -2 & -.1 & .006 \\
\hline 132 & $M-1$ & M 43701 & 35 & -150 & -10 & 25 & 50 & .1 & \\
\hline 133 & MOE-1OS & $\bar{M} 43714$ & 12 & -75 & 15 & 80 & 25 & .2 & \\
\hline 134 & MIE-IOS & $\underline{M} 43724$ & 238 & -75 & 5 & 12 & 30 & -.1 & .004 \\
\hline 136 & $M-2$ & $\bar{M} 43726$ & 39 & -75 & -15 & 9 & 45 & .2 & .02 \\
\hline 138 & MOE-11S & $\underline{M} 43721$ & -20 & I.S. & -20 & 16 & -20 & .3 & .01 \\
\hline 139 & $M 1 E-11 S$ & M 43700 & -20 & I. S. & -15 & 19 & 45 & .4 & \\
\hline 140 & $M-3$ & $\bar{M} 43702$ & 1 & -30 & 10 & 5 & 6 & -.1 & \\
\hline 141 & $M-4$ & $\underline{M} 43696$ & -6 & -150 & -10 & 4 & 20 & .4 & \\
\hline & $M-7$ & $\underline{\bar{M}} 43703$ & -3 & -75 & -5 & 7 & 05 & -.1 & \\
\hline & $M-6$ & $\bar{M} 43704$ & 8 & -30 & 34 & 1 & 14 &, 1 & \\
\hline & $M-5$ & $\underline{\bar{M}} 43711$ & 1 & -30 & -2 & -1 & 2 & .2 & \\
\hline
\end{tabular}

$\underline{M}=\operatorname{Mulch} \quad \underline{S}=$ Soil 
Table 11

Stream Sediment Analyses

\begin{tabular}{|c|c|c|c|c|c|c|c|c|c|}
\hline $\begin{array}{l}\text { Map } \\
\text { No. }\end{array}$ & $\begin{array}{c}\text { Fieid } \\
\text { No. }\end{array}$ & $\begin{array}{c}\text { Analytical } \\
\text { Code No. }\end{array}$ & $\begin{array}{c}U \\
P P E\end{array}$ & $\begin{array}{c}v \\
\mathrm{ppm}\end{array}$ & $\begin{array}{l}\text { Mo } \\
\text { ppm }\end{array}$ & $\begin{array}{l}\text { As } \\
\text { ppm }\end{array}$ & $\begin{array}{l}\text { Cu } \\
\mathrm{ppm}\end{array}$ & $\begin{array}{l}M_{n} \\
\%\end{array}$ & $\begin{array}{r}2 n \\
\% \\
\end{array}$ \\
\hline 1 & RAC-10 & & & & & & & & \\
\hline 2 & $\begin{array}{l}\text { OW-900N } \\
\text { RAC-11 }\end{array}$ & 43733 & 7 & -30 & -2 & 2 & -2 & -.1 & .003 \\
\hline 3 & $\begin{array}{l}300 \mathrm{E}-500 \mathrm{~N} \\
\text { RAC- } 12\end{array}$ & 43734 & 8 & -30 & -2 & 2 & -2 & .1 & .001 \\
\hline & $650 \mathrm{E}-450 \mathrm{~N}$ & 43735 & 33 & -30 & -2 & 2 & -2 & -.1 & .003 \\
\hline 4 & $C-1$ & 43727 & 554 & -30 & -2 & 5 & -2 & -.1 & .002 \\
\hline 5 & $\mathrm{C}-2$ & 43728 & 315 & -30 & -2 & 3 & -2 & -.1 & .003 \\
\hline 6 & $C-3$ & 43729 & 253 & -30 & -2 & 2 & -2 & -.1 & .002 \\
\hline 7 & $c-4$ & 43730 & 291 & -30 & -2 & 3 & -2 & .1 & .004 \\
\hline 8 & $:-5$ & 43731 & 198 & -30 & -2 & 4 & -2 & -.1 & .003 \\
\hline 9 & $c-6$ & 43732 & 77 & 100 & -2 & h & 4 & -.1 & .005 \\
\hline
\end{tabular}


Table 12

Sem1-Quantitative Spectrographic Analyses of Six Geobotanical Samples

\begin{tabular}{|c|c|c|c|c|c|c|}
\hline Map No. & 98 & 118 & 97 & 91 & 83 & 4 \\
\hline Type of Sample: & $\begin{array}{c}\text { Lodgepole } \\
\text { Pine }\end{array}$ & $\begin{array}{l}\text { Lodgepole } \\
\text { Plne }\end{array}$ & $\begin{array}{l}\text { Lodgepole } \\
\text { Plne }\end{array}$ & $\begin{array}{c}\text { Western } \\
\text { Cedar }\end{array}$ & Spruce & $\begin{array}{l}\text { Stream } \\
\text { Sediment }\end{array}$ \\
\hline Lab. No. & 43341 & 43382 & 43428 & 43458 & 43543 & 43727 \\
\hline The followir & are report & s oxides of & he elements & indicated & & \\
\hline Element; & $\%$ & $\%$ & $\%$ & $\%$ & $\%$ & $\%$ \\
\hline$S i$ & 6. & 4. & 5 & 3. & 8. & N. i) . \\
\hline $\mathrm{Ca}$ & 12. & 12. & 12. & 40 & 15. & 0.25 \\
\hline rig & 8. & 15. & 6 & 5. & 20. & .35 \\
\hline$k$ & 18. & 30 & 15. & 15 & 18 & 5. \\
\hline $\mathrm{Na}$ & 3.5 & 3. & 3.5 & .6 & 3.5 & 6 \\
\hline$A \perp$ & 2.5 & 2. & 2.5 & .4 & 2.5 & 18. \\
\hline $\mathrm{p}$ & 3.5 & 4. & 5. & 3. & 6. & -- \\
\hline $\mathrm{Ee}$ & 1. & .8 & 1.2 & .5 & 2. & 7. \\
\hline wn & 1.2 & 2. & 1. & .08 & 4. & .3 \\
\hline B & .2 & .3 & .25 & .3 & 1. & -- \\
\hline $\mathrm{Pb}$ & .03 & .02 & .04 & .015 & .06 & .02 \\
\hline Ga & .001 & -- & .001 & -- & .001 & .01 \\
\hline Mo & - & -.002 & -- & -- & -- & - \\
\hline $\mathrm{Cu}$ & .02 & .015 & .02 & .003 & .02 & .001 \\
\hline Ib & .002 & -.001 & .002 & -.001 & .001 & .004 \\
\hline Zn & .35 & .15 & .4 & -- & .1 & -- \\
\hline T1 & .025 & .03 & .03 & .03 & .06 & .3 \\
\hline $\mathrm{Ag}$ & .0005 & .001 & -.0005 & -- & $-\infty$ & -- \\
\hline $7 x$ & .025 & .004 & .04 & .05 & .02 & .2 \\
\hline $\mathrm{NI}$ & .003 & .004 & .003 & .001 & .005 & .001 \\
\hline Sr & .04 & .03 & .02 & .05 & .05 & .01 \\
\hline $\mathrm{Cr}$ & .0005 & .0007 & -.0005 & -.0005 & .0008 & .0005 \\
\hline V & .002 & .002 & -.001 & -- & .002 & -- \\
\hline $\mathrm{Y}$ & .02 & .015 & .01 & .003 & .03 & .06 \\
\hline $\mathrm{Ba}$ & .01 & .01 & .01 & .03 & .01 & .015 \\
\hline
\end{tabular}

Balance in First five samples: Not Eound. N.D: S1 + nondetectables: Balance in "43727.

Urauium in ppn by

Eluorimetric

1020

573

2396

155

208

554 
R E F E R E N C E S

Brew, David A., Loney, Robert A., and Muffler, L. J. Pacrlck, 1966, Tectonic history of southeastern Alaska; in Tectontc History and Mineral Deposits of the Western Cordillera, published by the Canadian Institute of Mining and Metallurgy, $p$ 149-170.

Buddingron, A. F., and Chapin, Theodore, 1929, Geology and mineral deposits of southeastern Alaska: U.S. Geol. Survey Bu1l. 800,398 p.

Buffers, John, 1967, History of mines and prospects, Ketchikan district prior to 2952 : Alaska Dept, of Natural Resources, Division of Mines and Minerals, $32 \mathrm{p}$.

Cannon, Helen L., 1957, Description of indicator plants and methods of botanical prospecting for uranlun depostts on the Colorado Plateau: U. S. Geol. Survey Bu1l. $1030-M$, p $399-516$.

, 1960, Botantcal prospecting for ore deposils: Sclence, Sept. 2, 1960, v. 132, No. 3224, P 591-598.

, 1960, The development of botanical methods of prospecting for uranium on the Colorado Plateau: U. S. Ceol. Survey Bu11. 1085-A, 50 p.

, 1964, Geochemistry of rocks and related soils and vegetation in the Yellow Cat Area, Crand County, Utah: U, S. Geol. Survey Bu11. 1176, 127 p.

Cannon, Helen L, and Starretr, W. H., 1956, Botanical prospecting for uranium on La Ventana Mesa, Sandoval County, New Mexico: U. S. Geol. Survey Bul1, 1009-M, p 391-407.

Chapman, Roberc M., and Shackletle, Hansford T., 1960, Genchemical exploration in Alaska: U. S. Geol. Survey Prof. Paper 400-B, p B104-B107.

Cohen, Noel $L_{1}$, Brooks, Robert R, and Reeves, Roger D, 1969, Pathfinders in geochemical prospecting for urandum in New Zealand: Econ, Geol. v. 64, P 519-525.

Denny, Richard L., 1962, Alaska Department of Natural Resources, Division of Mines and Minerals, Report for the year 1962, p 89-93.

Eakins, Glibert R,, 1969, Uranium in Alaska; Alaska Dept, of Nacural Resources, Divis1on of Mines and Geology, Geologic Report No. 38, 50 p.

Eroelich, Albert J., and KleinhampI, Frank J., 1960, Botarical prospecting for urantum in the Deer Flat Area, White Canyon District, San Juan County, Utah: U. S. Geol. Survey Bul1. 1085-B, p 51-84.

Ginzburg, I. L. 1960, Principles of geochemical prospecting, Pergamon Press, translated from the Russian by Sockoloff, $311 \mathrm{p}$.

Kaufman, Alvin, 1961, Trends in Alaska is mineral industry: U. S. Bureau of Mines Infor. Cir, 8045, $43 \mathrm{p}$.

Lanphere, Marvin A., Mackevett, E. M., Jr., and Stern, T. W., 1964, Potassium-argan and lead-alpha ages of plutonic rocks, Bokan Mountain area, Alaska: Science, v. 145, no. 3633, p 705-707.

Lovering, T. S., 1959, Significance of accumulator plants in rock weathering: Geol. Soc. of America Bull., v. 70, p 781-800. 
Lovering, T. S., Lakins, Hubert William, Ward, Fredertck N., and Canney, Frank C., 1955, Use of geochemical techniques and methods in prospecting for uranium: U. S. Geol.

Survey Prof. Paper 300, p 659-666,

Mackevetr, E. M., Jr., 1959, Geology and ore deposits of the Ross-Adams uranium deposit, Alaska: Mining Engineering, Sept, 1959, p 915-919.

1963, Geology and ore deposits of the Bokan Mountain uraniumthorium area, southeastern Alaska: U. S. Geol. Survey Bul1. 1154, 125 p.

Shacklette, Hansford T., 1960, Soil and plant sampling of the Mahoney Creek lead-rinc deposit, Revillagigedo Island, southeastern Alaska: U. S. Geol. Survey Prof. Paper $400-B$, P B102-B107.

, 1965, Bryophytes associated with mineral deposits and solutions in Alaskai U. S, Geol. Survey Bull. 1198-C, 18 p.

Tuctle, O. F., and Bowen, N. L., 1958, Origin of granite in the light of experimental studles in the system MaAlSi308-KA1Si308-Si308-H20: Geo. Soc. America Memoir 74.

TwenhofEe1, William S., and Sainsbury, C, $\mathrm{I}_{1}, 1958$, Fault patterns in Southeastern Alaska: Bull. Geol. Soclety of America, v. 69, p 1431-1442.

U. S. Dept. of Commerce, Climates of the States, Climatography of the U. S., No, 60-49, Alaska, 1968, $23 \mathrm{p}$.

Warren, H. V., velavault, R. E., and Irish, R. 1., 1952, Biogeochemical investigations in the Pacific Nortiwest: Geol. Soc. America Bull. v. 63, p 437.

Whitehead, Neil E., and Brooks, Robert R., 1969, A comparative evaluation of scintillomerric, geochemical and blogeochemical methods of prospecting for uranium: Econ. Geol., v, 64, P. 50-56,

Wright, F. F., and Wright, C. W., 1908, The Ketchikan and K'rangell mining districts, Alaská: U. S. Geol. Survey Bull, 347, 210 p. 